\title{
UTILIZAÇÃO DE EXAUSTORES EÓLICOS NO CONTROLE DA TEMPERATURA E DA VENTILAÇÃO EM AMBIENTE PROTEGIDO
}

\author{
RENÉ Porfirio CaMponez Do BRASIL
}

Tese apresentada à Escola Superior de Agricultura “Luiz de Queiroz”, Universidade de São Paulo, para obtenção do título de Doutor em Agronomia, Área de Concentração: Irrigação e Drenagem.

P I R A C I C A B A

Estado de São Paulo - Brasil

Outubro - 2004 


\title{
UTILIZAÇÃO DE EXAUSTORES EÓLICOS NO CONTROLE DA TEMPERATURA E DA VENTILAÇÃO EM AMBIENTE PROTEGIDO
}

\author{
RENÉ Porfirio CAMPonez Do BRASIL \\ ENGENHEIRO CIVIL
}

Orientador: Prof. Dr. MARCos Vinicius FolegatTI

\begin{abstract}
Tese apresentada à Escola Superior de Agricultura
“Luiz de Queiroz”, Universidade de São Paulo, para

obtenção do título de Doutor em Agronomia, Área de Concentração: Irrigação e Drenagem.
\end{abstract}

P I R A C I C A B A

Estado de São Paulo - Brasil

Outubro - 2004 
Dados Internacionais de Catalogação na Publicação (CIP)
DIVISÃO DE BIBLIOTECA E DOCUMENTAÇÃO - ESALQ/USP

Camponez do Brasil, René Porfirio

Utilização de exaustores eólicos no controle da temperatura e da ventilação em ambiente protegido / René Porfírio Camponez Do Brasil. - - Piracicaba, 2004.

$74 \mathrm{p}$.

Tese (Doutorado) - - Escola Superior de Agricultura Luiz de Queiroz, 2004.

Bibliografia.

1. Ambiente protegido (plantas) 2. Conforto térmico das construções 3.

Exaustores 4. Ventilação I. Título

CDD 631.583

"Permitida a cópia total ou parcial deste documento, desde que citada a fonte - O autor" 


\author{
À minha esposa Sely \\ Aos meus filhos Mariana e Afonso
}

Aos meus pais Moacyr $\boldsymbol{e}$ Therezinha (in memoriam)

Dedico. 


\section{AGRADECIMENTOS}

Meus sinceros agradecimentos a todas as pessoas e instituições que, de forma direta ou indireta, contribuíram para a consecução desse trabalho. Em especial, agradeço:

À Escola Superior de Agricultura “Luiz de Queiroz” - ESALQ/USP - através do Departamento de Engenharia Rural pela oportunidade de realizar o curso de pósgraduação.

Ao Prof. Dr. Marcos Vinícius Folegatti, pela confiança depositada, amizade e sempre presente orientação.

Aos professores do Departamento de Engenharia Rural, pela oportunidade concedida para a realização do curso de Pós-Graduação e pelos ensinamentos ao longo do mesmo.

Ao CNPq, pela concessão da bolsa de estudo.

Ao colega Roberto Terumi Atarassi, pela colaboração e amizade na elaboração e condução do experimento.

Aos colegas de curso, Carmelo, Edivaldo Casarini, Enio F.F. Silva, Flávio F. Blanco, Luiz Fernando S. M. Campeche e Ronaldo Resende, pelo apoio, sugestões e pela convivência e amizade.

Aos funcionários do Laboratório de Solos e Manejo de Irrigação, Gilmar Batista Grigolon, Sr Antonio Gozzo, António César S. Rocha (in memorian), Hélio Toledo Gomes, Davilmar Aparecida D. Collevatti, Sandra Regina T. Silveira Mello e Vanda Macedo Zambello, pela ajuda prestada em todas as etapas deste estudo. 


\section{SUMÁRIO}

Página

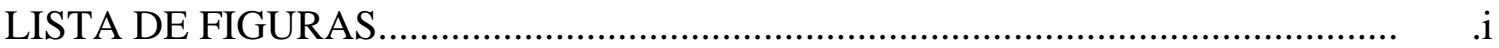

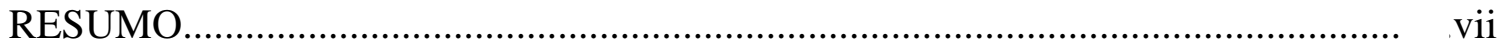

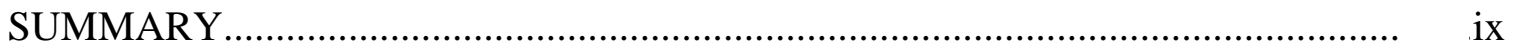

1 INTRODUÇÃO.................................................................................

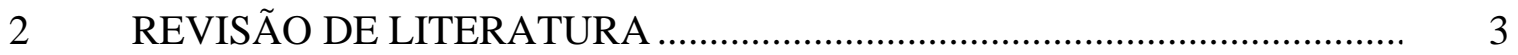

$2.1 \quad$ Temperatura....................................................................................

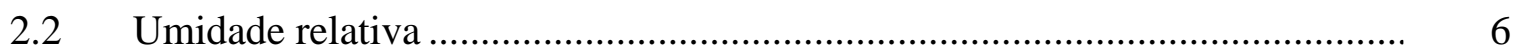

2.3 Radiação solar ..............................................................................................

2.4 Balanço de energia ....................................................................................

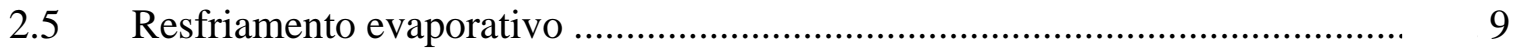

2.6 Ventilação..............................................................................................

2.6.1 Ventilação natural ................................................................................... 12

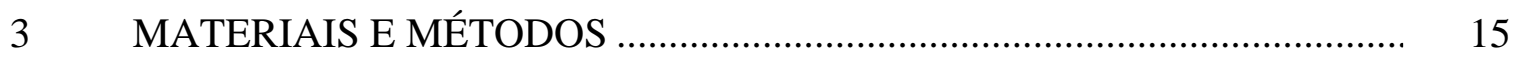

3.1 Caracterização do local e período de experimentação. ........................................ 15

3.2 Instalação dos exaustores eólicos na estufa....................................................... 17 
3.3 Variáveis meteorológicas internas e externas ........................................... 21

3.4 Temperatura do ar no ambiente protegido ................................................ 22

3.5 Distribuição vertical e horizontal de temperatura do ar (isotermas)............... 24

3.6 Manejo de cortinas do ambiente protegido............................................... 25

3.7 cálculo da eficiência do rebaixamento de temperatura do ar .......................... 26

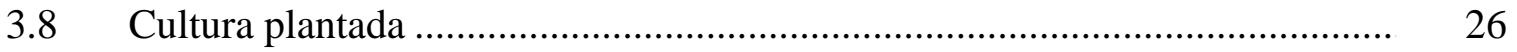

3.9 Determinação da rotação do exaustor eólico................................................ 27

3.10 Determinação da capacidade de ventilação dos exaustores eólicos ................ 27

3.11 Cálculo da perda de calor através da ventilação ............................................ 29

$4 \quad$ RESULTADOS E DISCUSSÃO ........................................................... 31

4.1 Variação da temperatura e determinação das temperaturas médias................ 31

4.2 Efeito do manejo de cortinas na temperatura dos ambientes protegidos ........ 33

4.2.1 Cortinas laterais e frontais fechadas .......................................................... 33

4.2.2 Cortinas laterais e frontais abertas com $1,0 \mathrm{~m}$........................................... 35

4.2.3 Cortinas laterais abertas com $1,0 \mathrm{~m}$ e cortinas frontais totalmente fechadas...

4.2.4 Cortinas laterais totalmente fechadas e cortinas frontais abertas com 1,0m... 50

4.2.5 Cortinas laterais e frontais abertas com 1,0m com apenas o exaustor central aberto.

4.3 Determinação da capacidade de ventilação dos exaustores eólicos ................. 
4.3.1 Determinação do número de rotações para fazer uma troca de ar no ambiente 


\section{LISTA DE FIGURAS}

Página

1 Passagem do ar fresco no sistema lantermin.

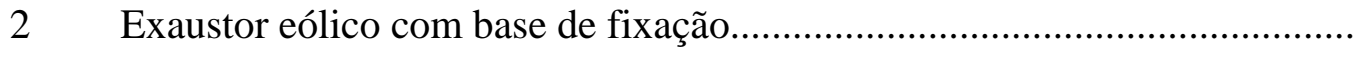

3 Ambientes protegidos utilizados no experimento, em Piracicaba, SP.......... 15

4 Dimensões do ambiente protegido no sentido transversal............................

5 Localização dos exaustores eólicos na cobertura da estufa.

6 Esquema de instalação do exaustor eólico e do sistema de fechamento, na cobertura da estufa.

7 (a) instalação do exaustor no teto utilizando tubos de metalon e (b) detalhe do sistema de fechamento do exaustor.

8 (a) Sistema de aquisição de dados CR23X; (b) sensores de radiação global, umidade relativa e temperatura do ar, velocidade e direção do vento externas à casa de vegetação.

9 Localização dos termopares na direção horizontal dentro do ambiente protegido.

10 Localização dos termopares na direção vertical dentro do ambiente protegido. 
11 Planta baixa dos ambientes protegidos com a localização do corte longitudinal (L-L) e dos cortes transversais C1, C2, C3, C4, C5 e C6.........

12 Anemômetro ultra-sônico modelo CSAT3 da Campbell Scientific Inc instalado próximo a entrada do exaustor eólico central.

13 Perfis verticais da temperatura do ar no eixo longitudinal central dos ambientes protegidos: (a) temperatura média as 13:30h dia 29/06, (b) temperatura média as $13: 30 \mathrm{~h}$ dia 04/07.

14 Variação da temperatura do ar nos ambientes protegidos (CE) com exaustor eólico e (SE) sem exaustor e (Ext) no ambiente externo no dia $29 / 06 / 04$

15 Temperaturas médias obtidas ao longo do dia 13 de abril nos ambientes protegidos cultivados com pimentão, com as cortinas frontais e laterais abertas com $1 \mathrm{~m}$ de altura e os três exaustores eólicos abertos

16 Gráficos das temperaturas médias no dia 13 de abril nas alturas de 0,5m; 1,0m; 2,0m e 3,0m, nos ambientes protegidos cultivados com pimentão, cortinas frontais e laterais abertas com $1 \mathrm{~m}$ de altura e os três exaustores eólicos abertos para: a) temperaturas médias das 6:00 - 18:00 horas e b) temperaturas médias as 14:45h.

17 Corte longitudinal do vão central dos ambientes protegidos cultivados com pimentão, com as cortinas frontais e laterais abertas com $1 \mathrm{~m}$ de altura, as 12:00 horas do dia 13 de abril: a) com os três exaustores eólicos abertos, e b) sem exaustor eólico 
18 Cortes das isotermas nas alturas de 0,5m, 1,0m, 2,0m e 3,0m dos ambientes protegidos cultivados com pimentão, com as cortinas frontais e laterais abertas com 1,0m de altura, as 12:00 horas do dia 13 de abril: (a), (c), (e), e (g) com os três exaustores eólicos abertos, e (b), (d), (f), e (h) sem exaustores eólicos...........................................................................

19 Cortes transversais do ambiente protegido com exaustores eólicos, cultivado com pimentão, com as cortinas frontais e laterais abertas com 1,0m de altura, as 12:00 horas do dia 13 de abril: (a) corte 1; (b) corte 2;

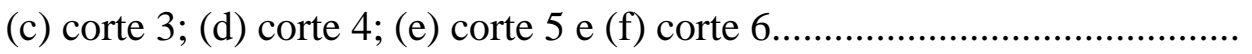

20 Cortes transversais do ambiente protegido sem exaustor cultivado com pimentão, com as cortinas frontais e laterais abertas com 1,0m de altura, as 12:00 horas do dia 13 de abril: (a) corte 1; (b) corte 2; (c) corte 3; (d) corte 4; (e) corte 5 e (f) corte 6.

21 Temperaturas médias obtidas ao longo do dia 17 de maio, com as estufas com cultura de pimentão, com as cortinas frontais totalmente fechadas, as cortinas laterais abertas com 1m de altura e apenas o exaustor eólico central aberto

22 Gráficos das temperaturas médias no dia 17 de maio nas alturas de 0,5m; 1,0m; 2,0m e 3,0m, para: (a) temperaturas médias das 0-6:00 horas e (b) temperaturas médias as 6:45 horas

23 Corte longitudinal do vão central dos ambientes protegidos cultivados com pimentão, com as cortinas frontais fechadas e as cortinas laterais abertas com 1m de altura: a) com apenas o exaustor eólico central aberto, e b) sem exaustor eólico, as 6:45h do dia 17 de maio..... 
24 Cortes das isotermas nas alturas de 0,5, 1,0, 2,0 e 3,0 metros dos ambientes protegidos: a), c), e), e g) com apenas o exaustor eólico central aberto, e b), d), f), e h) sem exaustor eólico, as 6:45h do dia 17 de maio....

25 Cortes transversais do ambiente protegido com exaustores eólicos, cultivado com pimentão, com as cortinas frontais fechadas e as laterais abertas com 1,0m de altura, as 6:45h do dia 17 de maio: (a) corte 1; (b) corte 2 ; (c) corte 3; (d) corte 4; (e) corte 5 e (f) corte 6.

26 Cortes transversais do ambiente protegido sem exaustor, cultivado com pimentão, com as cortinas frontais fechadas e laterais abertas com 1,0m de altura, as 6:45h do dia 17 de maio: (a) corte 1; (b) corte 2; (c) corte 3; (d) corte 4; (e) corte 5 e (f) corte 6

27 Temperaturas médias obtidas ao longo do dia 14 de junho, com as estufas sem cultura, com as cortinas laterais totalmente fechadas e as cortinas frontais abertas com 1m de altura e apenas o exaustor eólico central aberto

28 Gráficos das temperaturas médias dos ambientes protegidos sem cultura, com as cortinas laterais fechadas e as frontais abertas com 1,0m de altura, no dia 14 de junho nas alturas de 0,5m;1,0m;2,0m e 3,0m, para: a) temperaturas médias das 0-6:00 horas e b) temperaturas médias as 6:45 horas.

29 Corte longitudinal do vão central dos ambientes protegidos sem cultura, com as cortinas laterais fechadas e as frontais abertas com 1,0m de altura: a) com apenas o exaustor eólico central aberto, e b) sem exaustor eólico, as 6:45h do dia 14 de junho, no horário de temperatura mais baixa............. 
30 Cortes das isotermas nas alturas de 0,5, 1,0, 2,0 e 3,0 metros dos ambientes protegidos sem cultura, com as cortinas laterais fechadas e as frontais abertas com 1,0m de altura: a), c), e), e g) com apenas o exaustor eólico central aberto, e b), d), f), e h) sem exaustor eólico, no dia 14 de junho as 6:45h, horário de temperatura mais baixa

31 Cortes transversais do ambiente protegido com exaustores eólicos, sem cultura, com as cortinas laterais fechadas e as frontais abertas com 1,0m de altura no dia 14 de junho as 6:45h: (a) corte 1; (b) corte 2; (c) corte 3; (d) corte 4; (e) corte 5 e (f) corte 6

32 Cortes transversais do ambiente protegido sem exaustor, sem cultura, com as cortinas laterais fechadas e as frontais abertas com 1,0m de altura no dia 14 de junho as 6:45h: (a) corte 1; (b) corte 2; (c) corte 3; (d) corte 4; (e) corte 5 e (f) corte 6

33 Temperaturas médias obtidas ao longo do dia 21 de abril, com as estufas cultivadas com pimentão, com as cortinas laterais totalmente fechadas, as cortinas frontais abertas com 1m de altura e apenas o exaustor eólico central aberto

34 Gráficos das temperaturas médias dos ambientes protegidos cultivados com pimentão, as janelas laterais fechadas e as janelas frontais abertas com 1,0m de altura, e apenas o exaustor central aberto, no dia 21 de abril nas alturas de $0,5 \mathrm{~m} ; 1,0 \mathrm{~m} ; 2,0 \mathrm{~m}$ e $3,0 \mathrm{~m}$.

35 Corte longitudinal do vão central dos ambientes protegidos sem cultura, com as janelas laterais fechadas e as janelas frontais abertas com 1,0m de altura: (a) com apenas o exaustor eólico central aberto, e (b) sem exaustor eólico. 
36 Cortes das isotermas nas alturas de 0,5, 1,0, 2,0 e 3,0 metros dos ambientes protegidos com as cortinas laterais fechadas e as frontais abertas com 1,0m de altura: a), c), e), e g) com apenas o exaustor eólico central aberto, e b), d), f), e h) sem exaustor eólico, as 14:45h do dia 21 de abril

37 Cortes transversais do ambiente protegido com apenas o exaustor eólico central aberto, com as cortinas laterais fechadas e as frontais abertas com 1,0m de altura no dia 21 de abril as 14:45h: (a) corte 1; (b) corte 2; (c)

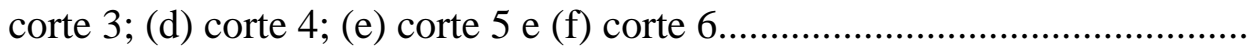

38 Cortes transversais do ambiente protegido sem exaustor, com as cortinas laterais fechadas e as frontais abertas com 1,0m de altura no dia 21 de abril as 14:45h: (a) corte 1 ; (b) corte 2; (c) corte 3; (d) corte 4; (e) corte 5 e (f) corte 6

39 Gráfico da capacidade de ventilação dos exaustores eólicos, movidos apenas pela energia do vento, e com cortinas abertas a $1,0 \mathrm{~m}$ e $0,5 \mathrm{~m}$...........

40 Gráfico da diferença da troca de ar em função da rotação do exaustor, com a abertura das cortinas laterais e frontais a $1,0 \mathrm{~m}$ e a $0,5 \mathrm{~m}$ de altura

41 Gráficos de eficiência: rotação x taxa de ventilação, para: (a) exaustores eólicos movidos por motor, e (b) exaustores eólicos movidos apenas pelo vento. 


\title{
UTILIZAÇÃO DE EXAUSTORES EÓLICOS NO CONTROLE DA TEMPERATURA E DA VENTILAÇÃO EM AMBIENTE PROTEGIDO
}

\author{
Autor: RENÉ PORFIRIO CAMPONEZ DO BRASIL \\ Orientador: Prof. Dr. MARCOS VINÍCIUS FOLEGATTI
}

\section{RESUMO}

O objetivo geral desse trabalho foi o de avaliar a utilização de exaustores eólicos no controle da temperatura e da ventilação no interior do ambiente protegido. Esse trabalho foi realizado em dois ambientes protegidos na área experimental do Departamento de Engenharia Rural, da escola Superior de Agricultura "Luiz de Queiroz”, da Universidade de São Paulo em Piracicaba, SP. Os ambientes protegidos estão instalados no sentido leste-oeste, com dimensões de 6,4m de largura por 17,5m de comprimento, sendo que, em um deles foram instalados três exaustores eólicos na cobertura. A avaliação da distribuição espacial da temperatura do ar (em graus centígrados) no interior dos ambientes protegidos foi realizada através da medição com termopares (cobre-constantã) instalados formando malhas, com espaçamento entre eles de $3,0 \mathrm{~m}$ e nas alturas de $0,5 \mathrm{~m}, 1,0 \mathrm{~m}, 2,0 \mathrm{~m}$ 3,0m e 4,0m em relação ao solo, constituindo um conjunto de 78 pontos de amostragem, e os valores de temperatura coletados foram armazenados em um sistema de aquisição de dados. A utilização de exaustores eólicos em ambientes protegidos, apesar de não reduzir significativamente a temperatura do ar nos períodos diurnos, mostrou-se eficaz no controle das temperaturas do ar, melhorando a sua distribuição tanto no perfil vertical como no horizontal, deixando-a uniforme, 
principalmente na altura da abertura das cortinas. No período noturno, principalmente nas noites de temperaturas mais baixas, manteve as temperaturas internas superiores ao outro ambiente protegido, e ao ambiente externo em até $4^{\circ} \mathrm{C}$. A combinação do manejo de cortinas e do uso de exaustores eólicos auxiliados por motor, para utilização nos momentos de aumento de temperatura ou falta de ventos, podem contribuir na redução da temperatura. A utilização dos exaustores eólicos melhora o controle da ventilação otimizando o "efeito termo sifão" ou processo convectivo, através do manejo adequado das cortinas, independente da direção e velocidade dos ventos. A taxa de ventilação do ambiente protegido no experimento com os exaustores movimentados apenas pelo vento foi de 0 a 5 trocas por hora, enquanto que, utilizando os motores auxiliares a taxa foi de 9 a 11 trocas por hora.A análise da distribuição da temperatura do ar por meio de isotermas permitiu uma visão global instantânea dos efeitos do uso de exaustores eólicos retirando a massa de ar quente instalada próxima à cobertura do ambiente protegido, na melhora da distribuição de temperatura do ar, tornando-a mais uniforme e homogênea. 


\title{
THE USE OF ROTARY TURBINE VENTILATOR FOR CONTROLLING THE AIR TEMPERATURE AND VENTILATION IN GREENHOUSE
}

\author{
Author: RENÉ PORFIRIO CAMPONEZ DO BRASIL \\ Adviser: Prof. Dr. MARCOS VINÍCIUS FOLEGATTI
}

\section{SUMMARY}

The objective of this study was to evaluate the use of rotary turbine ventilators on the control of air temperature and ventilation in a plastic greenhouse. The experiment was carried out in two plastic greenhouses disposed on East-West direction at the Department of Rural Engineering of College of Agriculture Luiz de Queiroz, University of São Paulo, Piracicaba, São Paulo State. The plastic greenhouses had a dimension of $6.4 \mathrm{~m}$ width and $17.5 \mathrm{~m}$ of length being one of them with three of rotary turbine ventilators on roof. The air temperature $\left({ }^{\circ} \mathrm{C}\right)$ spatial distribution was measured using 78 thermocouples (copper-constant) installed in a grid of $3.0 \mathrm{~m}$ horizontally and five different high, $0.5,1.0,2.0,3.0$ and $4.0 \mathrm{~m}$ from soil surface. The thermocouples were connected to a data logger system and the data were stored. Although the use of rotary turbine ventilator did not decrease the air temperature significantly in diurnal periods, they were efficient in control the air temperature by improving its distribution in horizontal and vertical profile, by keeping uniform, especially at the height of opened curtains. During the night periods, especially under low temperatures, they kept the internal air temperature above another greenhouse and environmental in almost $4^{\circ} \mathrm{C}$. The combination of curtains management and rotary turbine motor assisted ventilators can be 
used for decrease air temperature in moments of high temperature and without winds. The use of rotary turbine ventilators with curtains management improves the ventilation control by performing the convective process, independently of direction and velocity of the wind. Ventilation rate in greenhouse experiment with rotary turbine ventilators moved only by wind ranged from 0 to 5 changes per hour, whereas when assisted by motor system the ventilation rate ranged from 9 to 11 changes per hour. The analysis of air temperature distribution by isotherms lines allowed a global prompt vision of use of rotary turbine ventilators on removing the hot air mass near to the greenhouse roof and improving the distribution of air temperature that became more uniform and homogeneous. 


\section{INTRODUÇÃO}

O uso do plástico na agricultura tem sido uma alternativa na proteção das culturas frente às adversidades climáticas, como a chuva e o vento, principalmente em regiões onde o clima é um fator limitante de produção.

Segundo Tápia (1981), o material plástico mais empregado na agricultura mundial, é o polietileno de baixa densidade (PEBD), que apresenta boa transparência à radiação solar, porém apresenta uma elevada permeabilidade à radiação de onda longa.

Nas regiões Sul e Sudeste do Brasil, o interesse dos produtores pela produção em ambientes protegidos tem crescido bastante, pois possibilita o aumento da produtividade e qualidade dos produtos, alem de possibilitar produção fora das épocas convencionais alcançando melhor preço de venda.

A floricultura é a atividade que mais tem investido em tecnologia de produção em ambiente protegido no país, devido principalmente ao elevado nível de exigência do mercado consumidor, e ao alto valor econômico que este produto atinge. Essa técnica também é utilizada na produção de alimentos, basicamente hortaliças, como alface, abobrinha, pepino, pimentão, além do tomate e do morango.

Embora o aumento observado na área cultivada ambientes protegidos tenha sido considerável, as informações técnicas são escassas e pouco divulgadas, não apresentando a mesma evolução. Para a manutenção das condições ideais de produção das culturas em ambientes protegidos, são essenciais o conhecimento do microclima e a sua interação com os vários elementos que compõe o sistema, como temperatura, umidade relativa do ar, ventilação e fases da cultura. 
Para Furlan (2001), um aspecto a ser estudado sobre o cultivo em ambiente protegido nas regiões tropicais e subtropicais é a atenuação de altas temperaturas que são prejudiciais ao crescimento e produção de algumas culturas. Em geral, altas temperaturas do ar no interior de ambientes protegidos, diminui o rendimento e a qualidade dos produtos, chegando a produzir em alguns casos extremos a morte de plantas. 


\section{REVISÃO DE LITERATURA}

O cultivo em casas-de-vegetação permite uma série de vantagens: aumento de produtividade, melhoria na qualidade dos produtos, precocidade, menor lixiviação dos nutrientes do solo, controle mais eficiente de pragas e doenças e proteção contra intempéries climáticas como: chuva, vento, granizo e frio (Oliveira, 1997). Entretanto, a estufa plástica se comporta insatisfatoriamente do ponto de vista térmico, uma vez que durante o período diurno ocorrem temperaturas elevadas, que dificilmente são evitadas com a ventilação natural, e à noite, com freqüência, ocorrem temperaturas inferiores às críticas das plantas cultivadas (Martinez Garcia, 1986), além de outros problemas enfrentados por parte dos produtores, sendo as principais citadas por Oliveira (1995): dificuldade no controle das altas temperaturas e da umidade do ar, iluminação inadequada, difícil controle de pragas e doenças depois de instaladas.

Considerando que as coberturas plásticas criam condições bastante diferentes daquelas encontradas a céu aberto, e que são impermeáveis aos líquidos, impedindo a entrada da água da chuva, torna-se extremamente importante um melhor conhecimento das exigências hídricas das plantas no interior de estufas, uma vez que a irrigação será, na maioria das vezes, a única forma de suprimento de água e poderá afetar alguns elementos meteorológicos muito importantes ao desenvolvimento das plantas, como temperatura e umidade relativa do ar (Farias et al.,1994).

O efeito da estufa sobre a temperatura do ar está intimamente relacionado com o seu efeito sobre o balanço de energia, sendo, portanto, dependente dos fatores que definem seu comportamento com relação a este balanço, tais como condições da superfície da cobertura e do ângulo de incidência da radiação solar sobre a cobertura (Martinez Garcia, 1978; Prados, 1986). Além destes, outros fatores podem, também, 
alterar o efeito da cobertura sobre a temperatura do ar, como o tipo de solo e, principalmente, o tamanho da estufa e seu volume (Seemann, 1979).

Além da ventilação, outros sistemas são utilizados como forma complementar para reduzir a temperatura no interior da estufa, tais como sombreamento, irrigação e umedecimento. O sombreamento reduz a luminosidade interior da estufa de forma a atenuar as altas temperaturas, entretanto, alguns tipos de malhas de sombreamento podem reduzir a taxa de renovação de ar da estufa, diminuindo o efeito de descenso da temperatura interna. Quanto aos sistemas de irrigação, eles não atuam diretamente sobre o ar interno da estufa, e sim sobre sua cobertura plástica, que é molhada de forma contínua com uma fina película de água, obtendo desta maneira um certo resfriamento. Os sistemas de umedecimento estão baseados no consumo de energia que se dá na passagem do estado líquido da água ao estado de vapor. O calor necessário para esta mudança de fase é cedido mediante o contato do ar com a água aspergida, que apresenta então decréscimo em sua temperatura, provocando desta maneira a diminuição da temperatura interna da estufa. É um processo adiabático e a entalpia permanece constante (Matallana \& Montero, 1993).

Segundo Boulard et al (1990), os processos de evaporação e condensação tem influência direta no microclima de uma estufa e, conseqüentemente, na sua capacidade de propiciar condições satisfatórias às culturas.

\section{$2.1 \quad$ Temperatura}

O polietileno transparente de baixa densidade (PEBD) apresenta uma alta transparência à radiação solar global incidente (de 70 a 90\%) e transparência semelhante para a radiação de onda longa (TAPIA, 1981), determinando que as temperaturas noturnas e mínimas do interior da estufa não sejam muito diferentes às do ambiente externo. Resultados experimentais mostram que as temperaturas mínimas do ar são, em média, no interior da estufa 1,0 a $3,0^{\circ} \mathrm{C}$ superiores ao ambiente externo (Villele, 1983). Esta diferença depende principalmente das propriedades óticas do plástico, volume de ar armazenado (tamanho da estufa), vedação das paredes e condições meteorológicas do 
ambiente externo como velocidade do vento, umidade do ar e balanço global de radiação. Entretanto, ocorrem dias em que a temperatura mínima do ar no interior da estufa é inferior, originando o fenômeno da inversão térmica (Herter \& Reisser Junior, 1987; Andriolo et al, 1989).

Farias et al (1993), concluíram que a estufa de PEBD altera acentuadamente os valores da temperatura máxima do ar; aumenta a amplitude diária da umidade relativa do ar, não alterando os valores médios e que o efeito da cobertura plástica sobre a temperatura e umidade relativa do ar está intimamente relacionado com as condições atmosféricas do ambiente externo. Observaram ainda que em dia claro, a temperatura do ar no interior da estufa esteve ao longo do dia todo, acima da verificada a céu aberto, tendo a diferença variada de 0,5 a $9,0^{\circ} \mathrm{C}$, e que as maiores diferenças ocorreram nos horários de temperatura do ar mais elevadas (das 12 às 16 horas), o que evidencia o maior efeito da cobertura plástica sobre as temperaturas máximas encontrado por Martin et al, (1982).

Montero \& Antón (1994), relatam quatro fatores que influenciam a redução de temperatura: ventilação ou renovação do ar, evapotranspiração da cultura, radiação solar e evaporação de água dentro do ambiente protegido. Desses quatro fatores básicos, a radiação solar interna e a adição de umidade por evaporação de água são facilmente medidos ou calculados mas a taxa de ventilação e a taxa de transpiração apresentam certas dificuldades de quantificação.

Schneider et al (1998), estudando diferentes tecnologias para diminuição de temperaturas no interior de estufas plásticas, testaram inicialmente a técnica de caiação, que consiste na pulverização na face interna da cobertura plástica de uma mistura de $10 \%$ de cal apagada em água, e do sombreamento, colocação de uma malha de sombra com permeabilidade de $70 \%$ na altura do pé direito da estufa ( $2 \mathrm{~m})$, e concluíram que, o uso destas técnicas possibilitou a redução média de $3^{\circ} \mathrm{C}$ na temperatura comparativamente com a estufa plástica testemunha, ambas com cortinas de ventilação abertas durante o dia. Mesmo com esta redução, as temperaturas no interior da estufa são 
superiores ao ambiente natural e a faixa ótima de crescimento das culturas cultivadas em estufa.

Furlan (2001), avaliando a utilização de nebulização e abertura de cortinas na redução da temperatura, concluiu que a combinação do manejo de cortinas e nebulização foi o mais eficiente sistema para redução da temperatura do ar no ambiente protegido a níveis muito próximos à temperatura do ar externa, atingindo em alguns casos, temperaturas abaixo das mesmas.

\subsection{Umidade relativa}

Os valores de umidade relativa do ar no interior das estufas são muito variáveis e estão intimamente relacionados aos valores de temperatura do ar. Assim para um mesmo conteúdo de vapor d'água no ar, a umidade relativa é inversamente proporcional à temperatura (Seemann, 1979 e Prados, 1986). Desta forma, durante o período diurno, com o aumento da temperatura, a umidade relativa diminui no interior da estufa, tornando-se pouco inferior à verificada externamente. Porém, durante a noite, a umidade relativa aumenta bastante, chegando quase sempre a $100 \%$ logo antes do nascer do sol, devido à queda acentuada de temperatura verificada no interior da estufa, e a retenção de vapor d'água pela cobertura (Tanaka \& Genta, 1982).

O conteúdo de vapor d'água do ar no interior da estufa é, também, muito influenciado pela evapotranspiração, que eleva a tensão de vapor d'água do ar no ambiente (Prados, 1986). A pequena permeabilidade do filme plástico ao vapor d'água (18 g.m dia a $38^{\circ} \mathrm{C}$ e $90 \%$ de umidade relativa) somado à baixa renovação do ar interno provoca um acúmulo de vapor d'água, difícil de ser removido (Robledo \& Martin, 1981; Bailey, 1985). Sistemas de ventilação eficientes são necessários para a remoção deste vapor d'água (Seemann, 1979).

Farias et al (1993), relatam que no início do experimento, quando a cultura estava pouco desenvolvida, os valores internos de umidade relativa do ar foram inferiores aos observados externamente, ocorrendo, em seguida, um período de equilíbrio entre os dois ambientes. Após o sétimo decêndio, os valores internos mostraram-se superiores aos 
observados externamente. Neste período, a cultura bastante desenvolvida liberou maior volume de água pela transpiração e, também, pela maior freqüência de irrigação (devido ao maior consumo de água pela cultura), provocando um aumento da tensão de vapor d'água interna e, conseqüentemente, da umidade relativa do ar no interior da estufa, acentuada pela pequena renovação da massa de ar.

Resultados semelhantes foram também encontrados por outros autores. Valores mais elevados de umidade relativa máxima no interior da estufa ocorreram, em geral, durante à noite, quando a mesma não ficou completamente fechada, retendo o vapor d'água neste ambiente, uma vez que o filme plástico é praticamente impermeável ao vapor d'água (Robledo \& Martin, 1981). A queda de temperatura, bastante acentuada, verificada entre os períodos noturno e diurno no interior da estufa, também contribuiu para que maiores valores de umidade relativa fossem ali alcançados pela redução da tensão de saturação de vapor d'água do ar (Seeman, 1979; Martinez Garcia, 1986; Prados, 1986 e Farias et al, 1993).

A ocorrência de menores valores de umidade relativa no interior da estufa pode ser explicada, segundo Martinez Garcia (1986) e Prados (1986), devido à íntima relação desta com a temperatura do ar, cujos maiores valores são atingidos, em geral, no período diurno, permitindo maior tensão de saturação de vapor d'água do ar. Como a estufa fica aberta durante este período, a tensão de vapor d'água interna não fica muito acima da verificada externamente, tendendo a equilibrar-se, propiciando então menor valor de umidade relativa no interior da estufa, devido apenas à maior temperatura e tensão de saturação internamente (Farias et al, 1993).

\subsection{Radiação solar}

Durante o dia, a radiação solar incidente compensa as perdas de calor que ocorrem através da cobertura, permitindo atingir temperaturas mais elevadas do que no ambiente externo devido ao menor volume de ar a ser aquecido e à redução da ação dos ventos no resfriamento do ambiente (Tanaka \& Genta, 1982; Martinez Garcia, 1986). Porém, à noite, não há incidência de radiação solar e a estufa continua perdendo energia, 
fazendo com que, às vezes, as temperaturas do ar internas sejam inferiores às externas, conforme verificado na comparação das temperaturas mínimas (Farias et al, 1993).

\subsection{Balanço de energia}

A cobertura de uma casa-de-vegetação altera o balanço de energia em relação ao ambiente externo. O filme de PEBD deixa passar em média, de 59 a 90\% da radiação solar (Farias et al., 1993a; Camacho et al., 1995; Fernandes, 1996; Souza \& Escobedo, 1997; Sentelhas et al., 1997; Folegatti et al., 1997). A cobertura também aumenta a proporção de radiação difusa, que, sendo multidirecional, penetra melhor no dossel da cultura, favorecendo o aproveitamento da energia para fotossíntese e aquecimento (Farias et al, 1993a). Outra alteração importante é a menor troca de ar no interior das casas-de-vegetação, que reduz as trocas de calor sensível e de vapor d'água entre o ambiente interno e externo. Associado à menor disponibilidade de radiação, tal condição promove menores taxas de evapotranspiração, em torno de 60 a $80 \%$ da verificada externamente (Montero et al., 1985; Farias et al., 1994; Martins \& Gonzalez, 1995). A redução na taxa de ventilação também gera temperaturas do ar maiores durante o dia, notado pelas maiores temperaturas máximas em relação à condição de campo (Farias et al., 1993b; Camacho et al., 1995, Pezzopane et al., 1995).

Trabalhos têm mostrado uma maior relação radiação líquida/radiação global no interior de casas-de-vegetação. Frisina \& Ecobedo (1999) trabalhando com alface em casa-de-vegetação de PEBD, verificaram, em média, uma relação de 0,684 no interior e 0,593 no exterior e um balanço de onda longa maior no exterior. Isso é explicado pelas maiores temperaturas no interior da casa-de-vegetação que promovem maiores perdas por irradiação, em relação ao ambiente externo. O saldo de radiação ainda é afetado pelo estágio da cultura, ligado principalmente ao aumento do índice de área foliar, que aumenta a porção da radiação interceptada e reduz a porção que atinge o solo. Isso foi verificado por Souza et al. (1999) em trabalho com feijão-vagem sob cobertura plástica, em que obtiveram melhores estimativas da radiação líquida para fases fenológicas do que para o ciclo como um todo. 


\subsection{Resfriamento evaporativo}

Os sistemas de resfriamento evaporativo consistem em mudar o ponto do estado psicrométrico do ar para maior umidade e menor temperatura, mediante o contato do ar com uma superfície umedecida ou liquida, ou com água aspergida ou pulverizada. Como a pressão de vapor do ar insaturado a ser resfriado é menor que a da água de contato, ocorre a vaporização da água. O resfriamento evaporativo é um processo adiabático, ou seja, não há nenhum ganho ou perda de calor e, portanto, a energia requerida para evaporar a água é suprida pelo ar com conseqüente umedecimento do ar insaturado e redução da temperatura do bulbo seco (Abreu et al, 1999).

Al-jamal (1994) analisando a distribuição temporal da temperatura do ar no interior do ambiente protegido comercial equipado com sistema de resfriamento evaporativo “pad”no sudoeste da Jordânia, constatou que em ambiente protegido fechado, a temperatura do ar não coincide com a temperatura máxima, devido a distribuição da radiação solar durante o dia. Constatou também que para condição de mesma umidade relativa, houve maior resfriamento quanto maior a taxa de renovação de ar, e que para uma mesma taxa de renovação de ar, houve maior resfriamento do ar com menor umidade relativa.

Com a utilização do resfriamento evaporativo e conseqüente aumento da umidade relativa do ar no período diurno, se não tivermos um sistema de ventilação que efetue a troca de ar dentro do ambiente protegido, no período noturno quando a temperatura externa é muito menor que a interna, poderemos aumentar ainda mais a umidade relativa do ar, atingindo o 100\%, o que prejudicaria a cultura.

\subsection{Ventilação}

A ventilação é fundamental para o controle da temperatura e da umidade do ar interna da estufa, e para isso existem diversos métodos utilizados, mas sem dúvida a maneira mais econômica e mais utilizada é a ventilação natural que utiliza dispositivos 
que nem sempre garantem a troca de ar necessária, nestes casos, Berninger (1989) recomenda o uso de extratores de ar.

A ventilação da estufa é fundamental por três razões básicas: assegura uma taxa mínima de $\mathrm{CO}_{2}$ para a vegetação, evita o excesso de umidade bem como o calor excessivo durante o dia. Obviamente, a maneira mais econômica de realizar a troca de ar no interior das estufas é através da ventilação natural; para tal pode-se empregar dispositivos estáticos de abertura das paredes ou laterais das mesmas por meio de comandos manuais ou mecânicos. Entretanto estes dispositivos nem sempre asseguram a renovação de ar necessária. Neste caso recomenda-se o uso de ventilação através de extratores de ar (Berninger,1989).

A capacidade de ventilação da estufa pode ser avaliada através do número de renovações do ar por hora, ou seja, o volume de ar que é renovado por unidade de tempo. Neste sentido é importante a quantificação deste parâmetro. A bibliografia a respeito do assunto indica que esta tentativa é difícil e complexa (Montero Camacho et al, 1992; Matallana Gonzales \& Marfa Pages, 1980), ficando evidente a necessidade de contar sempre com informações locais, de maneira individual para cada estufa estudada.

Berninger(1989) e Kittas(1986) recomendam para regiões mediterrâneas, que a eficiência de mecanismos de ventilação sejam baseadas em número de renovação de ar entre 30 e 60 trocas de ar por hora, de acordo com a dimensão da estufa, valores de radiação solar e salto térmico desejado.

Anton Vallejo et al (1992), utilizando em zonas de clima úmido sistema de ventilação com capacidade de 40 renovações de ar por hora, para uma radiação de 800 kw.m-2 obtiveram uma diferença de temperatura interna da estufa com relação ao exterior de aproximadamente $4^{\circ} \mathrm{C}$, sem uso de umedecimento. Quando o umedecimento foi utilizado, a temperatura interna foi igual a externa. Neste caso, a redução de temperatura foi alcançada combinando a nebulização com o sistema de ventilação, utilizando bicos de aspersão com vazão de 4,5 a 6,5 l.hora $^{-1}$ de água evaporada, com distribuição de um bico por $10 \mathrm{~m}^{2}$. 
Triki et al (1984) compararam quatro diferentes sistemas de ventilação e sua influência na distribuição de temperatura, mostrada por isotermas, cujas temperaturas foram coletadas a 1,5m de altura do solo. Os termopares foram instalados a 2,0m das paredes dos ambientes protegidos e a 4,0m da entrada da mesma, formando uma malha de três linhas de nove termopares espaçados de 7,0m entre eles. As dimensões dos ambientes protegidos eram de 64,0 x 8,0m com 3,2m de pé direito. Foi observado que a distribuição de temperatura foi mais homogênea em ambientes protegidos onde a ventilação lateral foi combinada com ventilação pelo teto. O uso de dois ventiladores resultou em distribuição de temperatura muito heterogênea, com acúmulo de calor no centro do ambiente protegido. A situação foi ligeiramente amenizada pelo uso de quatro ventiladores, mas houve uma boa melhora quando dois ventiladores foram combinados com um extrato no cume posicionado no centro do ambiente protegido. A comparação da distribuição de temperaturas pelo método octogonal mostrou melhor a influência positiva dos sistemas de ventilação na distribuição de temperatura em ambientes protegidos.

Vanhoutte \& Verlodt (1990), estudaram a distribuição de temperatura do ar em cinco ambientes protegidos na Tunísia equipados com diferentes sistemas de ventilação. A distribuição de temperatura do ar em ambiente protegido foi estudada por medidas simultâneas de temperatura usando termopares em diferentes pontos na seção vertical (27 pontos) e horizontal (45 pontos) em 4 níveis de altura $(0,5 \mathrm{~m}, 1,05 \mathrm{~m}, 1,60 \mathrm{~m}$ e 2,15m). O cálculo de isotermas em diferentes seções do ambiente protegido foi realizado por meio de regressão polinomial bidimensional e interpolação linear. Foram realizados uma análise comparativa dos resultados com os métodos e os desvios entre a imagem calculada e a temperatura medida e concluíram que para distribuição vertical, a regressão polinomial forneceu resultados com precisão similar bem como a interpolação linear. Entretanto, para distribuição horizontal, a interpolação linear pareceu ser o método mais correto.

Considerando-se a inter-relação entre os fatores que afetam a temperatura do ar do ambiente protegido, o controle ambiental durante as horas de sol é difícil. Dos quatro 
fatores básicos que afetam a temperatura do ar a radiação solar interna e adição de umidade por evaporação de água são facilmente calculadas, mas a taxa de ventilação e a taxa de transpiração apresentam certas dificuldades de quantificação. A precisão diminui à medida que não sabemos corretamente a taxa de ventilação externa ao ambiente e da mesma forma desconhecemos a taxa de consumo de água das culturas em uma escala curta de tempo (Montero \& Antón, 1994).

O efeito da redução de temperatura média do ar no ambiente protegido causado pela abertura de janela zenital foi maior com a menor abertura das cortinas laterais devido ao processo convectivo ou “efeito termo-sifão”. A distribuição da temperatura média do ar com as cortinas laterais abertas a 3,0 metros de altura praticamente não foi modificada pela abertura da cortina zenital, principalmente quando a velocidade do vento externo era elevada. O efeito foi maior com a abertura de cortinas a 0,5 metro de altura, quando ocorria menor fluxo de ar pelo manejo de cortinas laterais e maior efeito do processo convectivo (Furlan, 2001).

\subsubsection{Ventilação natural}

A ventilação natural é o deslocamento controlado e intencional de ar através de aberturas específicas (portas, janelas, lanternim, dutos, etc.) e dispositivos para ventilação, onde o fluxo e ar, que entra ou sai, depende da diferença de pressão entre o interior e exterior da estrutura e da resistência ao fluxo de ar oferecida pelas aberturas ou frestas. Ë a mais antiga e comum forma e ventilação, devido ao baixo custo inicial e baixo consumo e energia, entretanto, apresenta numerosas limitações, por ser dependente das forças naturais como: forças devido ao vento e diferença entre as temperaturas internas e externas da estrutura (Hellickson \& Walker, 1983).

Para Meneses \& Raposo (1987), a ventilação natural de instalações agrícolas é o método utilizado pelo homem, desde os primeiros tempos, para controlar, dentro de certos limites, o seu ambiente, podendo controlar a temperatura e a composição do ar dentro de uma instalação e alcançar valores convenientes daqueles parâmetros para a produção de animais e vegetais. 
Os principais sistemas propostos pela engenharia para combater problemas com o calor e renovar o ar são: Shed, Lanternin, Exaustores Estáticos e Exaustores Eólicos.

Os Sheds e Lanternins dependem do vento estar vindo de um sentido favorável. Nos dias de chuvas ou ventos fortes ocorrem à entrada de folhas, papéis, gravetos, poeira e água, pois sua intenção inicial era de jogar o vento para dentro do barracão produzindo assim a exaustão. Quando a corrente de ar é favorável, no caso dos Lanternins, a maior parte do vento passa direto pela abertura impedindo que o ar quente continue sua ascensão natural, o pouco vento que consegue entrar apenas empurra o ar quente para baixo agravando o problema (Figura 1). Com o Shed, além dos problemas acima, apenas uma das aberturas é capaz de receber o vento, as outras o recebem em quantidade muito pequena.

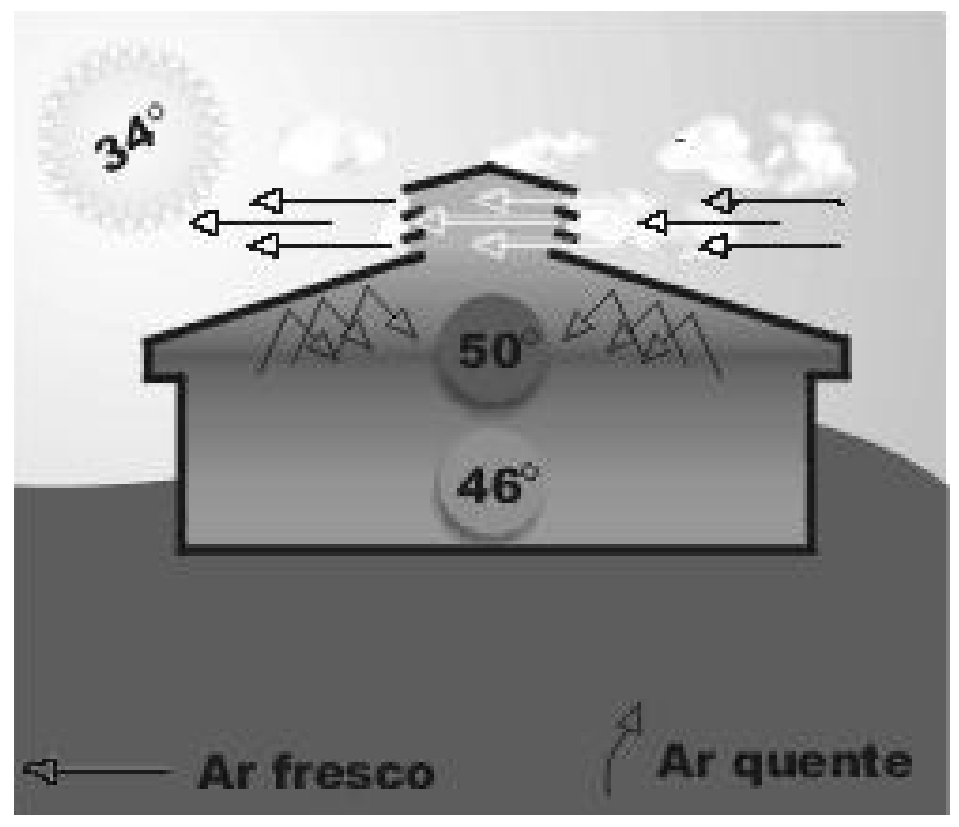

Figura 1- Passagem do ar fresco no sistema lantermin

Os exaustores estáticos por não possuírem movimento, não são capazes de provocar o vácuo necessário para a exaustão efetiva do ar quente, apenas aproveitam sua tendência natural de subir constituindo assim saídas para o ar, mas em vazões insatisfatórias. Alguns são providos de hélices muito leve que giram pela força de ascensão do ar quente, diminuindo ainda mais a abertura por onde a corrente passaria. 
Exaustor Eólico é um tipo de exaustor giratório acionado pela força do vento, com o propósito de renovar o ar do ambiente onde estiver instalado (Figura 2). O vento que incide sobre as palhetas do exaustor, promove o giro do aparelho diminuindo a pressão no seu interior, facilitando o escoamento da massa de ar quente contida no ambiente, para seu meio exterior. $\mathrm{Na}$ ausência do vento, o equipamento funcionará apenas pelo diferencial térmico entre as temperaturas externas e internas (convecção), resultando daí uma ventilação natural. A vazão do Exaustor Eólico varia com a velocidade do vento, com ventos de $10 \mathrm{~km}_{\text {.hora }}{ }^{-1}$ obteremos uma vazão de aproximadamente $4000 \mathrm{~m}^{3}$ hora $^{-1}$.

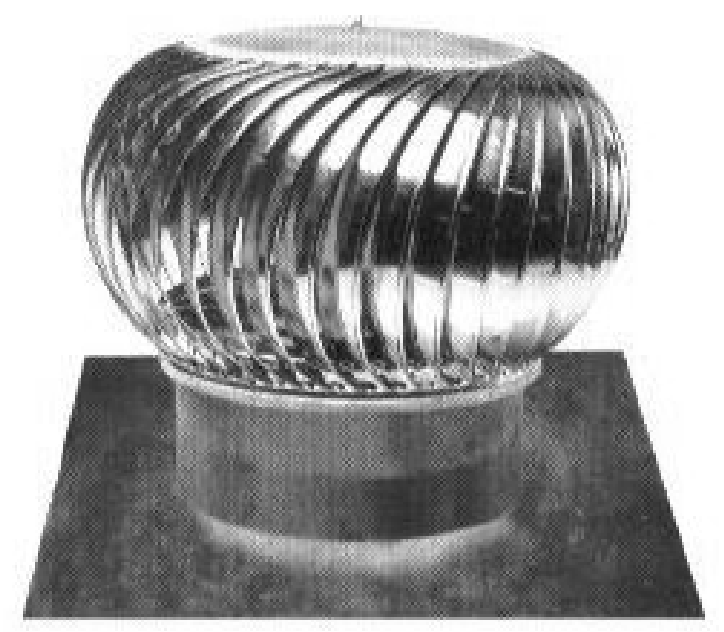

Figura 2- Exaustor eólico com base de fixação

O objetivo desse trabalho é o de avaliar a utilização de exaustores eólicos com diferentes manejos de cortinas laterais e frontais, no controle da temperatura do ar e da ventilação em ambientes protegidos. 


\section{MATERIAIS E MÉTODOS}

\subsection{Caracterização do local e período de experimentação.}

O presente trabalho foi realizado no período de 01/07/03 a setembro de 2004, em ambientes protegidos, na área experimental do Departamento de Engenharia Rural, da Escola Superior de Agricultura "Luiz de Queiroz", situada no município de Piracicaba, SP, cujas coordenadas geográficas são: Latitude $22^{\circ} 42^{\prime}$ S, Longitude $47^{\circ} 38^{\prime}$ W e altitude de 570 metros.

Segundo a classificação climática de Köppen, Piracicaba possui clima Cwa, ou seja, subtropical úmido, com estiagem no inverno. O solo do local do experimento é classificado como Terra Roxa Estruturada (Alfisol), série Luiz de Queiroz, plana.

A Figura 3 apresenta a área experimental em cultivo protegido do Departamento de Engenharia Rural com os ambientes protegidos utilizados.

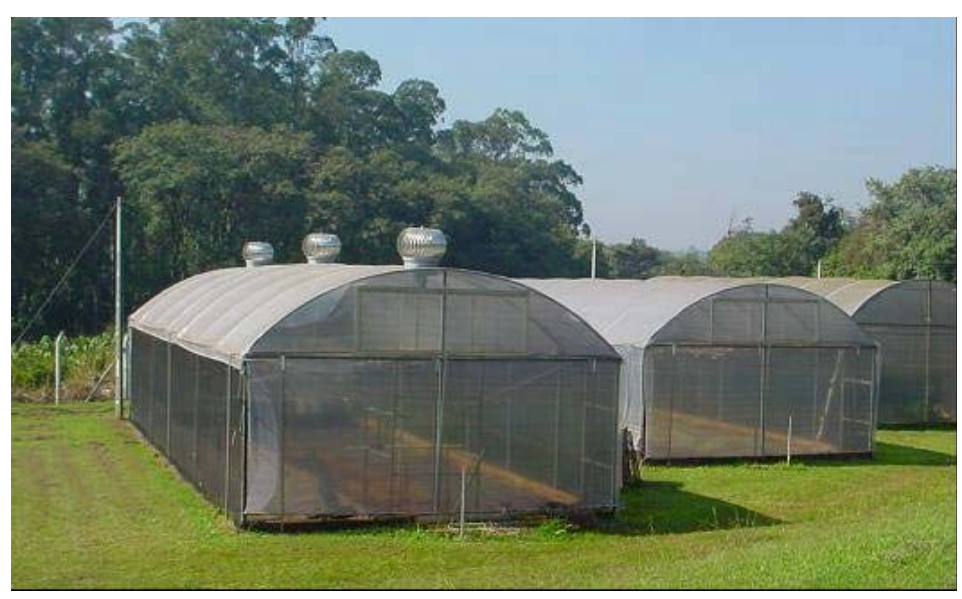

Figura 3- Ambientes protegidos utilizados no experimento, em Piracicaba, SP 
Foram instalados dois ambientes protegidos similares para a coleta e comparação dos dados, no sentido leste-oeste, tendo as seguintes características: dimensões de 6,4m de largura por 17,5m de comprimento; estrutura pré-fabricada de ferro galvanizado; pé direito de 3,0m; altura total de 4,2m; área total de 112,0 $\mathrm{m}^{2}$; espessura do plástico de 150 micra; filmes plásticos em PVC SANSUY com tratamento contra raios ultravioleta; janelas laterais e frontais fechadas com sombrite a $60 \%$ e plástico com mecanismo de abertura e fechamento.

Na Figura 4 estão representadas as dimensões transversais do ambiente protegido.

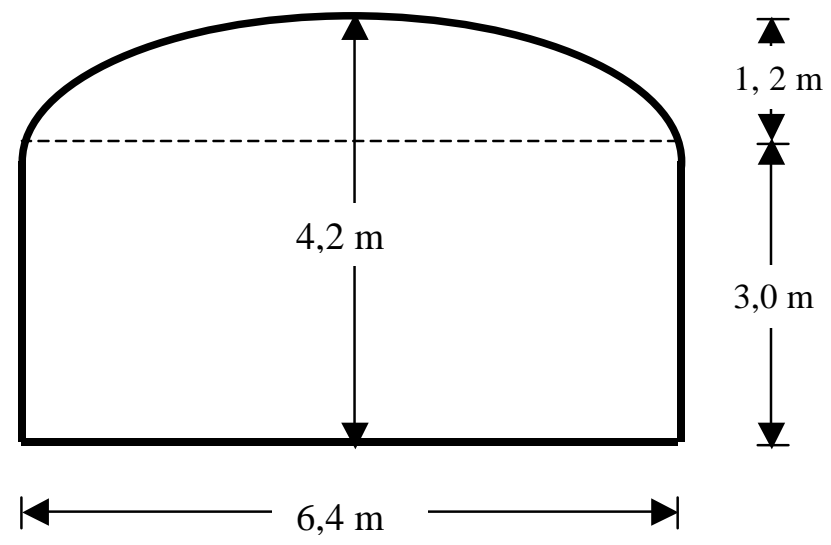

Figura 4- Dimensões do ambiente protegido no sentido transversal

Em um dos ambientes protegido, foi instalado um sistema de ventilação natural, composto por três exaustores eólicos de $80 \mathrm{~cm}$ de diâmetro, fabricados por Exaustores Taquaritinga, instalados na cobertura.

A opção pelo fabricante foi devido o equipamento possuir um sistema reforçado em sua estrutura para podermos fixar os sensores para executar às medições necessarias ao experimento. 


\subsection{Instalação dos exaustores eólicos na estufa}

Os números de exaustores eólicos a serem instalados foram calculados com base em volume de aproximadamente 30 trocas de ar por hora, de acordo com as equações abaixo, fornecidas pelo fabricante:

Cálculo do número de aparelhos:

$$
V t=V p d+V a
$$

Onde:

$V t$ - Volume total de ar do ambiente protegido;

Vpd - volume do pé direito do ambiente protegido;

$V a$ - volume do arco do ambiente protegido;

Cálculo do volume de ar contido no pé direito:

$$
\text { Vpd = L.C.Hpd }
$$

Onde:

Vpd - volume do pé direito do ambiente protegido;

$L$ - largura do ambiente protegido;

$C$ - comprimento do ambiente protegido;

Hpd - pé direito do ambiente protegido;

Então:

$V p d=6,4 \mathrm{~m} \times 17,5 \mathrm{~m} \times 3,0 \mathrm{~m}=336 \mathrm{~m}^{3}$

Cálculo do volume de ar contido no arco do ambiente protegido:

$$
V a=H a \cdot L \cdot C \cdot 0,67
$$

Onde: 
$\mathrm{Va}$ - volume do arco do ambiente protegido, $\mathrm{m}^{3}$;

$\mathrm{Ha}$ - altura do arco, m;

$L$ - largura do ambiente protegido, m;

$C$ - comprimento do ambiente protegido, $\mathrm{m}$;

Então:

$V a=1,2 \mathrm{~m} \times 6,4 \mathrm{~m} \times 17,5 \mathrm{~m} \times 0,67=90,048 \mathrm{~m}^{3}$

E, da equação (1), obtemos:

$V t=336 m^{3}+90,048 m^{3}=426,05 m^{3}$

Cálculo do vazão de ar desejada:

$$
V a h=V t . N
$$

Onde:

Vah - Vazão de ar, em $\mathrm{m}^{3}$.hora ${ }^{-1}$;

$V t$ - Volume total de ar do ambiente protegido, em $\mathrm{m}^{3}$;

$N$ - número de trocas de ar desejado

Então:

$V a h=426,05 \mathrm{~m}^{3} \times 30=12.781,44 \mathrm{~m}^{3}$

Cálculo do número de aparelhos necessários para atingir a vazão de ar desejada:

$$
N a p=\frac{V a h}{V e}
$$

Onde:

Nap - Numero de aparelhos

Vah - vazão de ar, em $\mathrm{m}^{3}$.hora ${ }^{-1}$ 
$V e$ - vazão do exaustor com ventos de $10 \mathrm{~km} \cdot \mathrm{h}^{-1}\left(4.000 \mathrm{~m}^{3} \cdot\right.$ hora $\left.^{-1}\right)$.

Então:

$$
\text { Nap }=\frac{12.781,44}{4.000}=3,195 . \text { aparelhos }
$$

O número de aparelhos para atingirmos a vazão desejada, que é de 30 trocas de ar por hora, foram de aproximadamente três exaustores.

A localização de instalação dos exaustores foi realizada da seguinte forma: um no vão central da estufa, e os outros dois, nos vãos mais próximos das partes frontais e fundos da estufa, locais que devido ao oitão em forma de arco, que é revestido de plástico, provocar maior retenção de ar quente neste ponto da estufa (Figura 5).

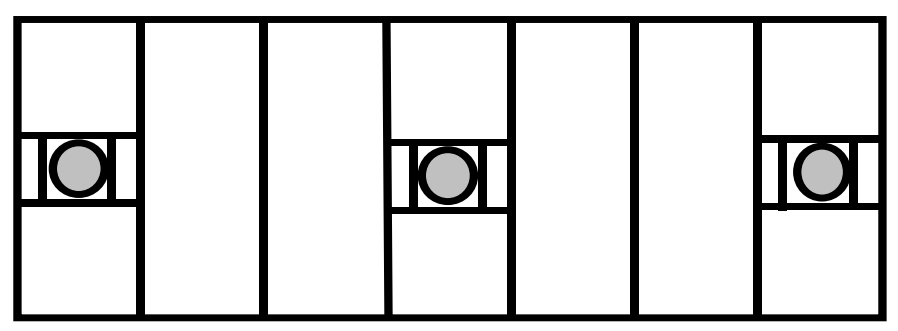

Figura 5- Localização dos exaustores eólicos na cobertura da estufa

Para a sustentação do exaustor no teto da estufa, foi necessário fazer um reforço entre os arcos, para que fosse possível instalar os equipamentos de forma a ficarem bem fixados e não danificarem o plástico da cobertura. Para isso foram utilizadas duas barras de tubos metalon colocados entre os arcos, espaçados de 0,8m, para assentarmos duas bases de fixação do exaustor, uma com a boca para baixo (interna), e a outra com a boca para cima (externa), ficando entre elas o plástico da estufa, que apenas após a fixação dessas bases através de rebites, foi executado a abertura do plástico.

Na base que ficou no interior da estufa, foi instalado um sistema de tampa para fechamento da saída de ar, para que seja possível avaliar a temperatura interna da estufa, com a utilização de um, dois ou três exaustores. 
Essas tampas são divididas em dois meio círculos, que serão acionadas individualmente, utilizando um sistema de cordas de nylon e roldanas, que foram instaladas nas laterais internas da estufa, o que permitiu o fechamento parcial ou total de cada exaustor. O esquema de instalação dos exaustores na estufa pode ser visualizado nas Figuras 6 e 7.

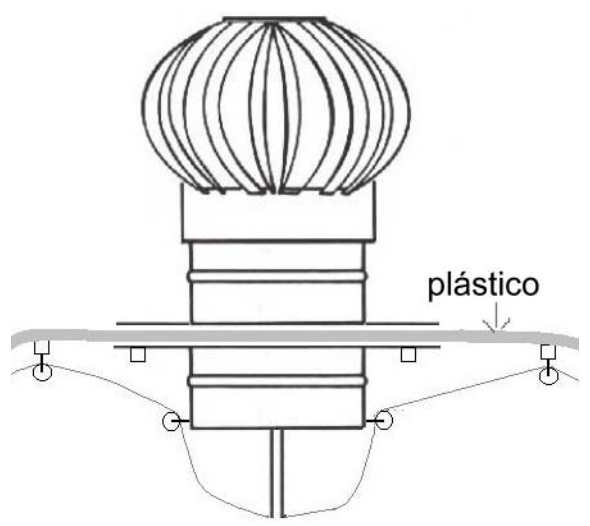

Figura 6- Esquema de instalação do exaustor eólico e do sistema de fechamento, na cobertura da estufa

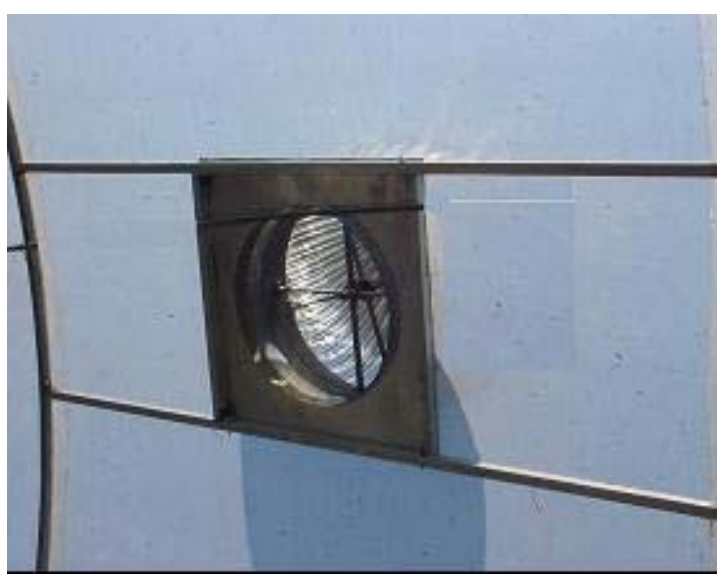

(a)

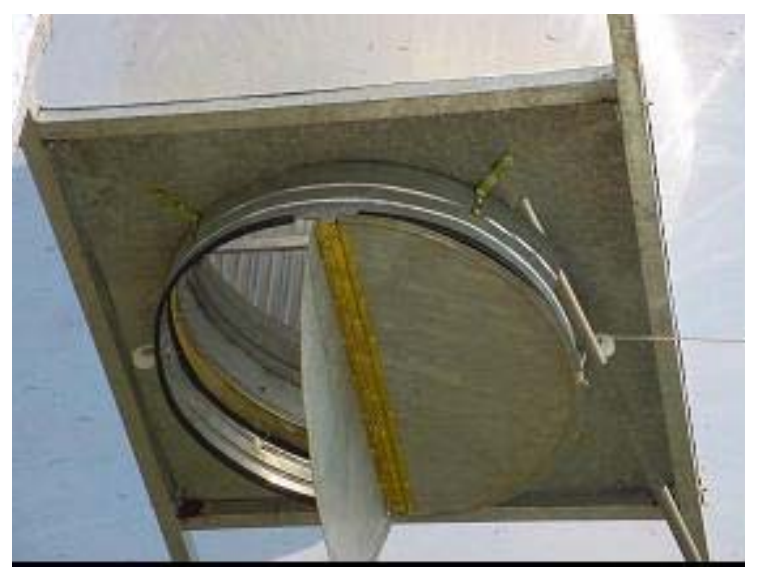

(b)

Figura 7- (a) instalação do exaustor no teto utilizando tubos de metalon e (b) detalhe do sistema de fechamento do exaustor 


\subsection{Variáveis meteorológicas internas e externas}

A aquisição dos dados meteorológicos, no interior e exterior dos ambientes protegidos, foram feitas através de sistemas de aquisição de dados, modelo CR10 e CR23X da Campbell Scientific Inc, programados para leituras a cada 5 segundos e gravação de médias a cada 15 minutos onde foram conectados os seguintes sensores:

Dentro da casa-de-vegetação:

- Radiação solar global interna à casa de vegetação, medida com piranômetro de termopilha, modelo CM3 da Kipp\&Zonen, instalado a 2m de altura;

- Perfil vertical e horizontal de medidas de temperatura do bulbo seco, obtidas por termopares de cobre-constantã;

- Velocidade do vento próximo ao exaustor eólico central, fornecida por um anemômetro ultra-sônico, modelo CSAT3, da Campbell Scientific Inc;

Também foram instalados dois conjuntos de tensiômetros em cada ambiente protegido, em profundidades de 10 e 30cm para fins de manejo da irrigação.

Fora da casa-de-vegetação:

- Radiação solar global, fornecido por um piranômetro (modelo: LI200X Pyranometer - Li-cor Inc.) instalado a 4,5m do solo;

- Temperatura e umidade relativa do ar, com sensores (modelo: HMP35C Temperature/RH Probe - Campbell Scientific; precisão de $\pm 0,1^{\circ} \mathrm{C}$ para temperatura e $\pm 3 \%$ para umidade relativa) instalados a $4,5 \mathrm{~m}$ do solo;

- Velocidade (modelo: 014A - Met One Instruments; threshold =0,45ms) e direção do vento (modelo: 024A - Met One Instruments, precisão $= \pm 5^{\circ}$ ), medidas a $4,5 \mathrm{~m}$ de altura. 


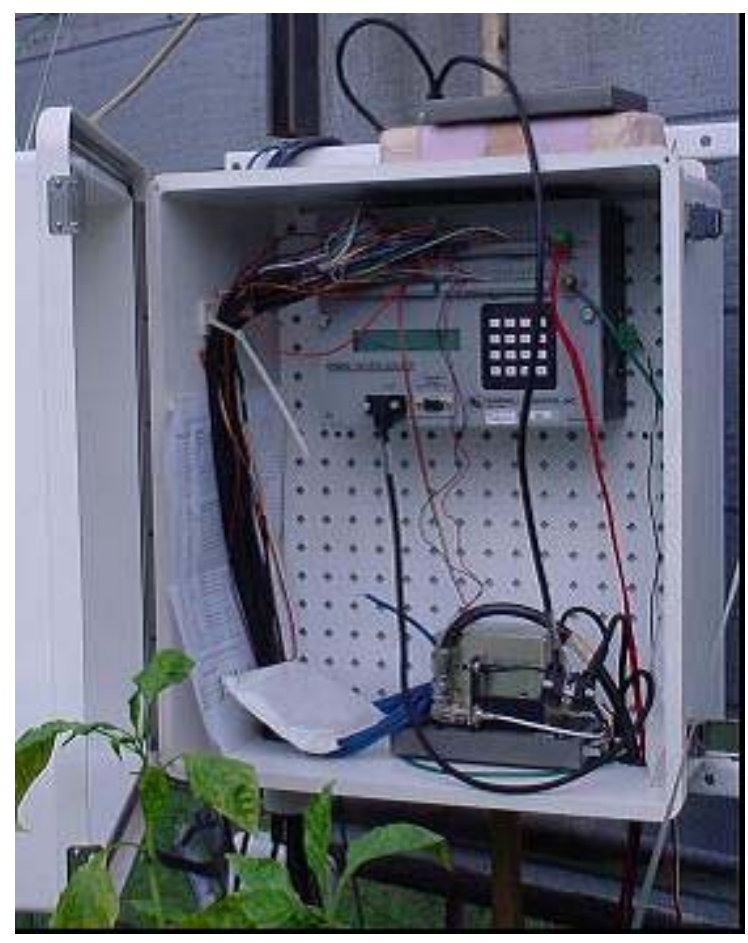

(a)

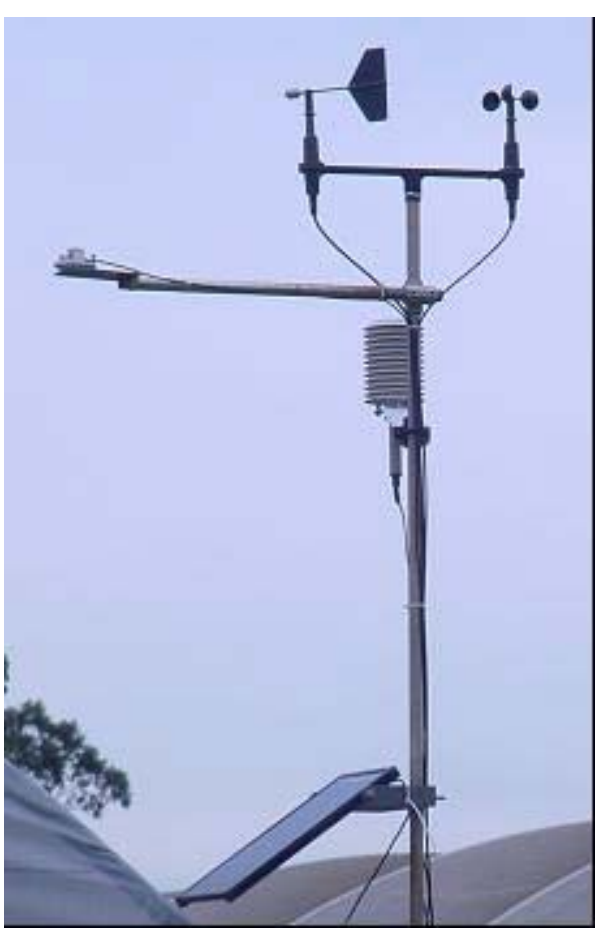

(b)

Figura 8- Sistema de aquisição de dados CR23X (a), sensores de radiação global, umidade relativa e temperatura do ar, velocidade e direção do vento externas à casa de vegetação (b)

\subsection{Temperatura do ar no ambiente protegido}

Com o propósito de caracterizar e avaliar o sistema de ventilação por exaustores eólicos em ambiente protegido foi realizada uma amostragem sistemática pelo uso de 78 termopares regularmente distribuídos nas três direções do espaço (comprimento, largura e altura). Os termopares, constituídos de pares termoelétricos de cobre-constantã foram instalados em micro-abrigos de PVC branco nos níveis correspondentes às alturas de 0,5m, 1,0m, 2,0m, 3,0m e 4,0m em relação ao nível do solo e com espaçamento horizontal entre eles de 3,0m. Esses termopares foram calibrados previamente em laboratório. 
A Figura 9 mostra a representação esquemática da localização das 18 estacas de sustentação dos termopares na direção horizontal e a Figura 10, a dos termopares na direção vertical.

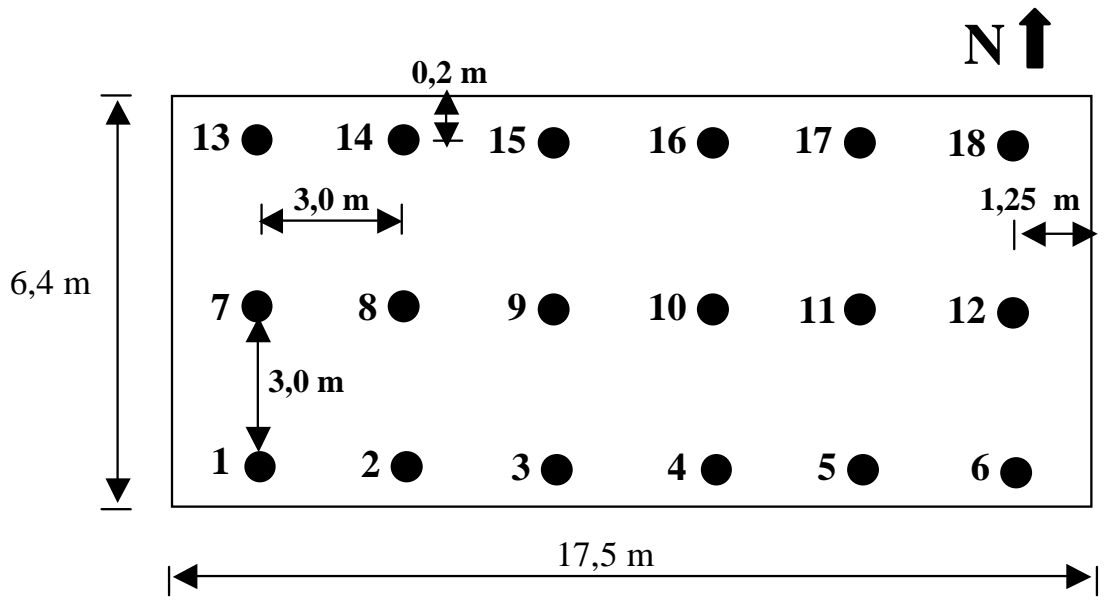

Figura 9- Localização dos termopares na direção horizontal dentro do ambiente protegido

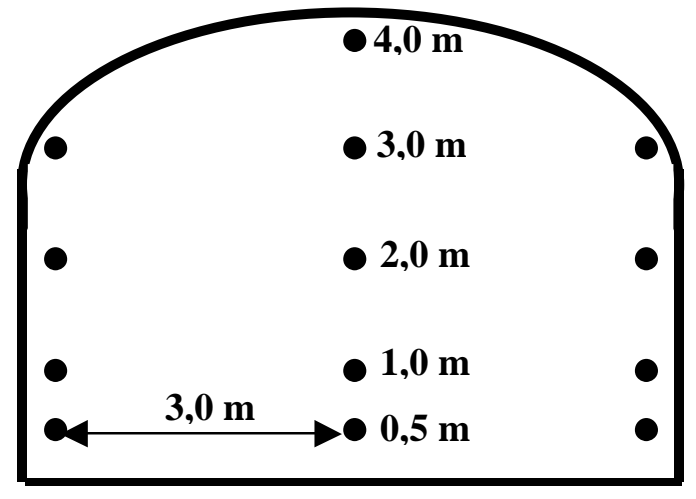

Figura 10-Localização dos termopares na direção vertical dentro do ambiente protegido

A distribuição dos termopares nas três direções do espaço (comprimento, largura e altura) foi determinada a partir da disponibilidade de equipamento para a coleta de dados, bem como das dimensões do ambiente protegido. 
Dois sistemas de aquisição de dados CR10 com quatro multiplexadores foram utilizados com o propósito de armazenar o sinal dos termopares instalados nos ambientes protegidos, com leituras a cada 5 segundos e média a cada 15 minutos.

Os pontos de amostragem formaram uma malha que permitiram traçar as isotermas, ferramenta esta, utilizada para a análise dos ambientes.

\subsection{Distribuição vertical e horizontal de temperatura do ar (isotermas).}

Para a determinação do gradiente térmico vertical no interior do ambiente protegido, foi utilizada a média de quatro pontos de amostragem para cada uma das cinco alturas acima do nível do solo $(0,5 ; 1,0 ; 2,0 ; 3,0$ e 4,0m). Os pontos amostrados corresponderam aos termopares instalados nas estacas 8, 9, 10 e 11, localizados na parte central do ambiente protegido.

Dentro de cada ambiente protegido foram coletados dados de janeiro de 2004 a outubro de 2004, nos 78 pontos de amostragem para a formação da malha e caracterização das isotermas, examinando dessa maneira, o perfil térmico no ambiente protegido de acordo com diferentes planos de seção e manejo realizado.

Uma simples representação gráfica das temperaturas do ar coletadas consistiu em plotar cada dado observado e construir superfícies isotérmicas a partir destes e às suas médias. Para cada manejo executado, foram construídas isotermas:

- do corte longitudinal (L-L) do centro do ambiente protegido, isto é, das estacas $7,8,9,10,11$ e 12;

- dos seis cortes transversais referentes as estacas 1-7-13 (C1-1), 2-8-14 (C2-2), 3-9-15 (C3-3), 4-10-16 (C4-4), 5-11-17 (C5-5) e 6-12-18 (C6-6);

- e aos termopares das 18 estacas a 0,5m, $1 \mathrm{~m}, 2 \mathrm{~m}$ e a 3,0m de altura em relação ao nível do solo e em diferentes horas do dia.

Na Figura11, podemos visualizar na planta baixa do ambiente protegido, o corte longitudinal (L-L) e os cortes transversais, C1; C2; C3; C4; C5 e C6. 


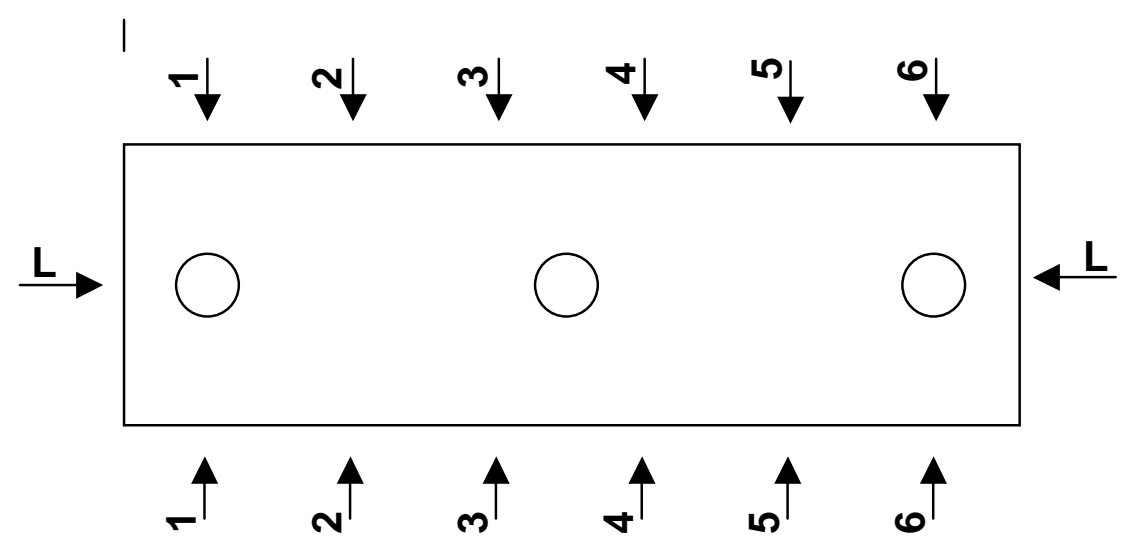

Figura 11-Planta baixa dos ambientes protegidos com a localização do corte longitudinal (L-L) e dos cortes transversais C1, C2, C3, C4, C5 e C6

Nos dois ambientes protegidos, foram obtidos, a partir de todos os termopares instalados em cada ambiente, os valores médios de temperatura do ar no interior de cada um destes ambientes ao longo do dia, e o perfil vertical de temperatura para cada manejo executado.

\subsection{Manejo de cortinas do ambiente protegido.}

Em cada período considerado, procurou-se verificar a variação temporal e espacial de distribuição de temperatura do ar no interior do ambiente protegido segundo o manejo executado, através da abertura e fechamento das cortinas laterais e frontais.

Os manejos foram executados no ambiente protegido com três exaustores eólicos abertos e no ambiente protegido sem exaustor:

- com as cortinas laterais e frontais fechadas.

- com as cortinas laterais e frontais a 0,5m de altura.

- com as cortinas laterais e frontais a 1,0m de altura.

- com as cortinas laterais a 1,0m de altura e as cortinas frontais fechadas.

- com as cortinas frontais a 1,0m de altura e as cortinas laterais fechadas. 


\section{7 cálculo da eficiência do rebaixamento de temperatura do ar}

O cálculo da eficiência do rebaixamento de temperatura do ar no ambiente protegido, foi realizada considerando uma temperatura do ar média diária para cada um dos ambientes protegidos (testemunha e ambiente com tratamento) e feita a relação:

$$
\mathrm{E}=\frac{\mathrm{Tt}-\mathrm{T}}{\mathrm{Tt}} \bullet 100
$$

em que:

$\mathrm{E}=$ eficiência da redução de temperatura do ar no sistema (\%).

$\mathrm{Tt}$ = temperatura do ar média do ambiente testemunha $\left({ }^{\circ} \mathrm{C}\right)$.

$\mathrm{T}$ = temperatura do ar média no ambiente manejado $\left({ }^{\circ} \mathrm{C}\right)$.

A temperatura média do ar dos ambientes protegidos foi calculada considerandose todos os termopares para cada horários de armazenagem dos dados (a cada 15 minutos), conforme descrito anteriormente.

\subsection{Cultura plantada}

Para condução do experimento, foi adotada a cultura do pimentão amarelo como padrão em termos de arquitetura e crescimento, para verificarmos o efeito da presença de cultura no deslocamento de ar e sua influência da distribuição da temperatura no interior do ambiente protegido. Foi utilizada a variedade de pimentão amarelo “Matador” da empresa Rogers, plantado em linhas simples, no espaçamento de 0,5m entre plantas na linha e 1,2m entre linhas somando um total de 155 plantas. Utilizou-se um sistema de tutoramento em "V” invertido, segundo recomendação de Goto \& Tivelli (1998), composto de mourões nas extremidades das ruas e caibros parafusados a 1,9m do solo por onde foi esticado um conjunto de arames de aço. Varas de bambu foram fixadas em espaçamento de 2,5m entre si ao longo da linha de plantio. Essa cultura foi escolhida por apresentar: crescimento arbustivo mais rígido, conseqüentemente menos dependente do tutoramento que outras culturas como tomateiro, pepineiro e assim menos 
influenciado pela condução; folhas relativamente grandes, simétricas e ciclo de crescimento longo (podendo a cultura permanecer produzindo por mais de 1 ano), possibilitando um estudo com grande variação de área foliar.

Cada fileira teve o solo coberto com mulching plástico de PEBD preto, com 0,35mm de espessura. A adubação de plantio foi baseada na análise de solo. O fornecimento de água foi feito via irrigação por gotejamento, com uma linha de irrigação para cada linha de plantio, sendo o intervalo e as lâminas de irrigação determinadas através de tensiometria com base na curva de retenção de água do solo do ambiente protegido. As adubações de cobertura foram realizadas via fertirrigação, em que os fertilizantes são aplicados juntamente com água de irrigação. O controle fitossanitário, condução da cultura e colheita foram realizados de acordo com as recomendações agronômicas e necessidades da cultura.

\subsection{Determinação da rotação do exaustor eólico}

Como as vazões de ar retiradas pelos exaustores eólicos variam com a velocidade do vento, e no catalogo do fabricante não constam informações do numero de rotações do exaustor em relação à velocidade do vento externo, foram instalados dois sensores, um ótico e um magnético (Reed Switch) para fazerem essa contagem.

Com associação do numero de voltas do exaustor com a velocidade do vento externo, medido pelo anemômetro, poderemos estimar a tiragem de ar pelos exaustores através da velocidade do vento que é mais fácil de ser medida.

\subsection{Determinação da capacidade de ventilação dos exaustores eólicos}

A capacidade de ventilação do ambiente protegido foi avaliada através do número de renovações do ar por hora, ou seja, o volume de ar que é renovado por unidade de tempo. Para calcularmos a capacidade de ventilação do exaustor eólico, determinamos a vazão utilizando a velocidade do ar retirado em $\mathrm{m} . \mathrm{s}^{-1}$, fornecido por um anemômetro ultra-sônico modelo CSAT3 da Campbell Scientific Inc., instalado próximo 
a entrada do exaustor eólico central, multiplicado pela área da entrada do exaustor em $\mathrm{m}^{2}$.

$$
Q=\operatorname{Var} . A e
$$

Onde:

$Q$ - vazão de ar no exaustor eólico, em $\mathrm{m}^{3} . \mathrm{s}^{-1}$;

$V_{a r}$ - velocidade do ar, em m.s ${ }^{-1}$;

$A_{e}$ - área da entrada do exaustor eólico, em $\mathrm{m}^{2}$;

A vazão total de ar retirada do ambiente protegido foi determinada, multiplicando a vazão calculada pelo número de exaustores eólicos instalados, portanto:

$$
Q t=Q . n .3600
$$

Onde:

$Q t$ - vazão de ar total do ambiente protegido, em $\mathrm{m}^{3} \cdot \mathrm{h}^{-1}$;

$Q$ - vazão de ar do exaustor eólico, em $\mathrm{m}^{3} . \mathrm{s}^{-1}$;

$N$ - numero de exaustores eólicos instalados;

Para determinarmos o numero de trocas de ar executadas pelos exaustores eólicos, dividimos a vazão total calculada, pelo volume de ar total contido no ambiente protegido, equação (1).

$$
N t a=\frac{Q t}{V t}
$$

Onde,

Nta - número de trocas de ar executadas por hora;

$Q t$ - vazão total de ar do ambiente protegido, em $\mathrm{m}^{3} \cdot \mathrm{h}^{-1}$;

$V t$ - volume total de ar do ambiente protegido, em $\mathrm{m}^{3}$. 
Para podermos determinar as vazões com diferentes rotações, utilizamos exaustores eólicos auxiliados por motor, que permitem um melhor controle da velocidade de giro, independente dos momentos de ventos fracos, ou ausentes.

Na Figura 12, podemos visualizar o sistema de motorização e a instalação do anemômetro ultra -sônico, para determinação da velocidade e a direção do vento nas coordenadas $\mathrm{x}, \mathrm{y}$ e $\mathrm{z}$.

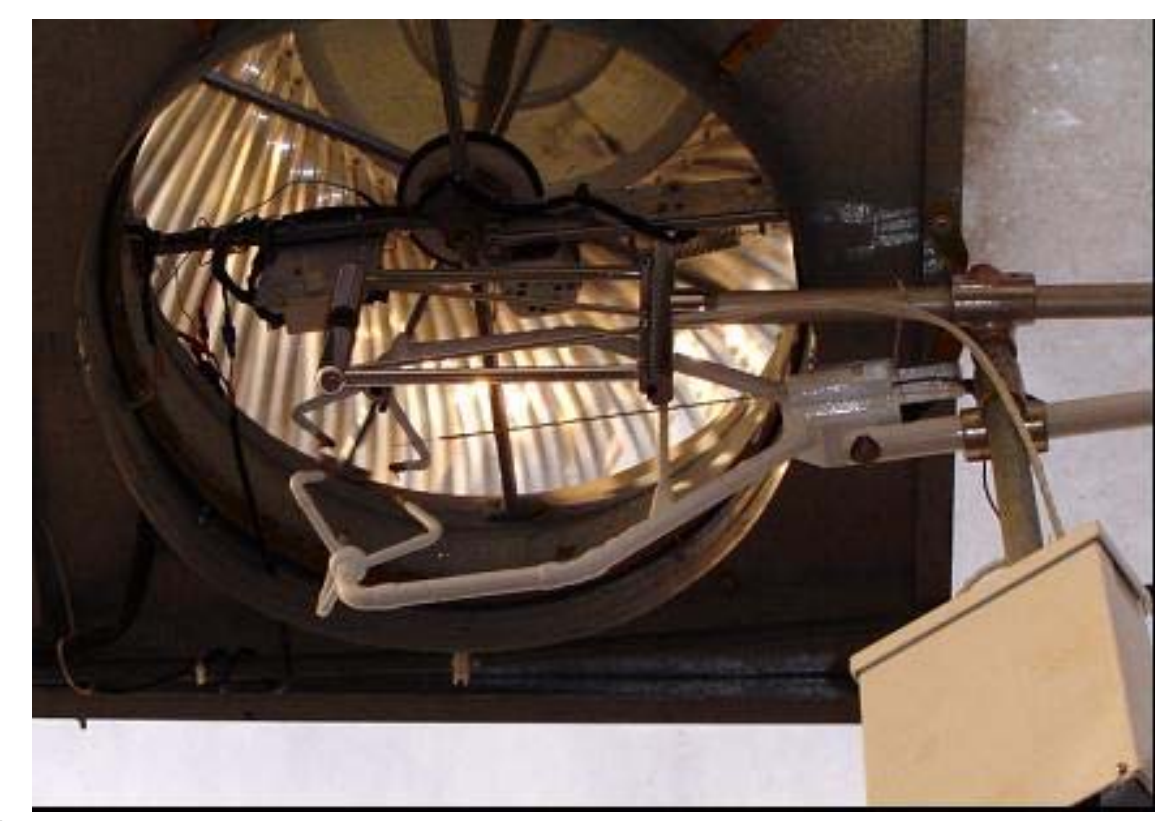

Figura 12-Anemômetro ultra-sônico modelo CSAT3 da Campbell Scientific Inc instalado próximo a entrada do exaustor eólico central

\subsection{Cálculo da perda de calor através da ventilação}

Para o calculo da perda de calor, utilizamos a metodologia utilizada por Atarassi (2000). Uma vez conhecida a vazão total do ambiente protegido, calculamos o coeficiente de perda de calor pela ventilação, através da equação:

$$
h_{V}=\frac{\rho_{a r} \cdot C_{p} \cdot Q_{T}}{A_{S}}
$$

Onde: 
$\mathrm{h}_{\mathrm{V}}-$ coeficiente de perda calor pela ventilação, $\mathrm{W} \cdot \mathrm{m}^{-2} \cdot \mathrm{K}^{-1}$;

$\rho_{a r}$ - massa específica do ar, kg. $\mathrm{m}^{-3}$;

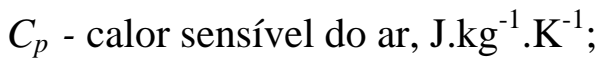

$Q_{T}$ - vazão total de ar pela ventilação, $\mathrm{m}^{3} \cdot \mathrm{s}^{-1}$;

$A_{S}$ - área do ambiente protegido, $\mathrm{m}^{2}$;

A perda de calor sensível através da ventilação é diretamente proporcional a diferença de temperatura entre o ambiente interno e externo (Boulard \& Baille, 1993) e obtido pela expressão:

$$
H_{V E N T}=h_{V} \cdot\left(T_{i}-T_{e}\right)
$$

Onde:

$H_{V E N T}$ - perda de calor sensível através da ventilação, W.m ${ }^{-2}$;

$h_{V}$ - coeficiente de perda de calor pela ventilação, W.m ${ }^{-2} \cdot \mathrm{K}^{-1}$;

$T_{i}$ - Temperatura interna do ambiente protegido, ${ }^{\circ} \mathrm{C}$;

$T_{e}$ - Temperatura externa do ambiente, ${ }^{\circ} \mathrm{C}$; 


\section{RESULTADOS E DISCUSSÃO}

A análise dos resultados para os diferentes manejos de cortinas laterais e aberturas dos exaustores eólicos realizados nos ambientes protegidos estão apresentados em itens de acordo com os tratamentos aplicados. A análise foi realizada de forma a se entender o processo ocorrido durante as 24 horas do dia, avaliando os efeitos da temperatura e da ventilação através da representação por meio de isotermas e gráficos, para os períodos diurnos e noturnos, juntos ou separadamente, para identificarmos as variações dos elementos meteorológicos, nas situações que apresentam as maiores dificuldades para o manejo dos ambientes protegidos.

Como a definição do local onde se devem instalar sensores para se conhecer valores médios de um elemento meteorológico é sempre questionável, inicialmente precisamos determinar através dos valores coletados esses pontos e suas posições dentro dos ambientes.

\subsection{Variação da temperatura e determinação das temperaturas médias.}

Vários fatores influenciam a temperatura do ar em ambientes protegidos tais como: ângulo de incidência da radiação solar, tipo de cobertura plástica, tipo de solo, tamanho e volume do ambiente protegido (Seeman, 1979). Portanto, a temperatura do ar no interior do ambiente protegido está intimamente ligada ao seu balanço de energia, dependendo dos processos de incidência da radiação solar, reflexão e reirradiação pelos objetos no interior do ambiente protegido, condução através da cobertura e paredes, renovação do ar e troca de calor com o solo (Farias et al., 1993). Desta forma, características que afetam tais processos de ganho e perda de energia, como volume de 
ar do ambiente protegido, condição atmosférica externa, área da superfície coberta, também condicionarão a temperatura do ar em ambientes protegidos (Furlan, 2001).

Para a determinação dos termopares que melhor representam os valores da temperatura média do ar dos ambientes protegidos, analisamos as medidas de temperaturas do ar coletadas através dos 78 pontos onde foram instalados termopares em cada um desses ambientes, calculamos a temperatura média de todo o ambiente, e localizamos a posição dos termopares que melhor representam esse valor. Dentre vários pontos que se aproximaram da média, quatro pontos se destacaram, os termopares localizados nas posições centrais dos ambientes, posições 8, 910 e 11 que podem ser visualizadas na Figura 9, na altura de 1,0m em relação ao nível do solo. Esses pontos por estarem próximos ao centro geométrico do ambiente sofrem menor influência da temperatura do ar externa nas laterais, obtendo assim maior uniformidade na distribuição da temperatura.

Para garantir que as temperaturas desses pontos representem a temperatura média do ar do ambiente protegido, aplicamos o teste t para cada um dos termopares em todos os dias analisados, e o resultado foi não significativo, portanto as médias podem ser consideradas praticamente iguais, como os resultados encontrados por Furlan (2001).

Como os valores desses pontos centrais representam bem a temperatura média do ar do ambiente protegido, usamos também as médias dos termopares nas alturas de 0,5m, $1,0 \mathrm{~m}, 2,0 \mathrm{~m}, 3,0 \mathrm{~m}$ e $4,0 \mathrm{~m}$ desses quatro pontos para representar as temperaturas nos perfis verticais da temperatura do ar no eixo longitudinal central dos ambientes protegidos.

Segundo Al-Jamal (1994) avaliar a adaptação do ambiente protegido através da medição em um ponto não dá a idéia da variação da temperatura e da sua distribuição dentro do ambiente protegido. Dessa forma, vários autores propuseram a análise da distribuição da temperatura do ar no interior do ambiente protegido por meio de vários pontos de amostragem, formando malhas e construindo linhas de distribuição de temperatura iguais no plano, ou seja, isotermas. 


\subsection{Efeito do manejo de cortinas na temperatura dos ambientes protegidos}

A quantidade de radiação luminosa que penetra no interior de um ambiente protegido depende do fluxo que chega à cobertura, do fluxo refletido, do fluxo absorvido e do poder de dispersão do material de cobertura, do fluxo absorvido pelo solo, do fluxo que é refletido pelo solo e do que é perdido para o exterior pela cobertura (Cermeño, 1994).

A temperatura do ar durante a noite, pode ser assumida como sendo igual a temperatura do ar no ambiente externo, mas, durante o dia a temperatura do ar dentro do ambiente protegido aumenta significativamente (Kittas, 1996).

Se a renovação de ar é elevada, pode-se chegar a uma elevada transpiração das plantas levando-as ao estresse e se a renovação de ar for baixa não há trocas com o ambiente externo, ocorrendo uma condição de elevada umidade relativa o que pode ser desfavorável à cultura pela redução da transpiração e pelo aumento das doenças (Baille ${ }^{1}$, citado por Montero et al 1990).

Os mecanismos de ventilação, especialmente os naturais, não dispensam o manejo adequado de abertura e fechamento das cortinas do ambiente protegido, pois dependerão das condições climáticas e meteorológicas locais.

\subsubsection{Cortinas laterais e frontais fechadas}

Nos ambientes protegidos sem cultura, com as cortinas laterais e frontais fechadas, observou-se temperatura média do ar de $49,5^{\circ} \mathrm{C}$ e $46,0^{\circ} \mathrm{C}$ no ambiente sem exaustor, e $47,0^{\circ} \mathrm{C}$ e $43,0^{\circ} \mathrm{C}$ no ambiente com os três exaustores eólicos abertos, nos dias $29 / 06$ e 04/07/04 respectivamente as 13:30h.

A distribuição do perfil vertical da temperatura média do ar, para os dias 29/06 e 04/07/04, podem ser visualizados na Figura13.

${ }^{1}$ BAILLE, A. La climatisation dês serres em periode estivale. Sem. AGRO-VETP. Athénes. P. 14-18, november, 1988. 


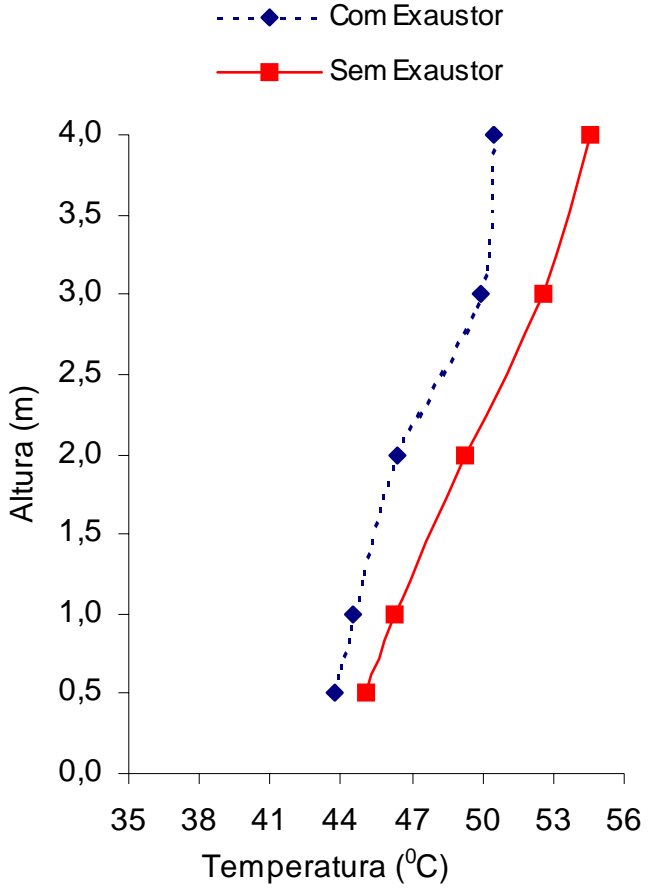

(a)

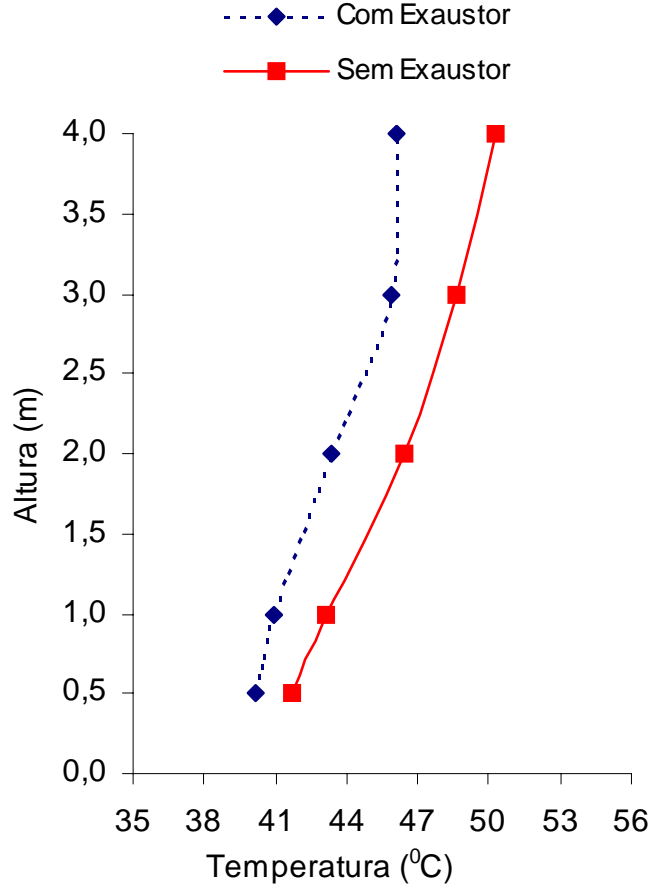

(b)

Figura 13-Perfis verticais da temperatura do ar no eixo longitudinal central dos ambientes protegidos: (a) temperatura média as 13:30h dia 29/06, (b) temperatura média as 13:30h dia 04/07

Na Figura 14, estão representadas as temperaturas médias internas dos ambientes protegidos com e sem exaustores eólicos e a temperatura externa, no período de 24 horas, em dia claro, com as cortinas laterais e frontais fechadas e os três exaustores eólicos abertos, no dia 29 de junho de 2004.

Com as cortinas fechadas, o desempenho do exaustor eólico é minimizado devido a não ocorrer movimentação de ar por ventilação no interior dos ambientes protegidos. As diferenças entre o ambiente protegido com exaustores eólicos e o sem exaustor foram mínimas, chegando ao valor máximo de $3,6^{\circ} \mathrm{C}$ às $9: 45 \mathrm{~h}$, mas observa-se que a temperatura do ar nos ambientes protegidos, estiveram acima da temperatura do ar externa ao longo do dia, chegando à diferença de até $21^{\circ} \mathrm{C}$ às $13: 30 \mathrm{~h}$. 


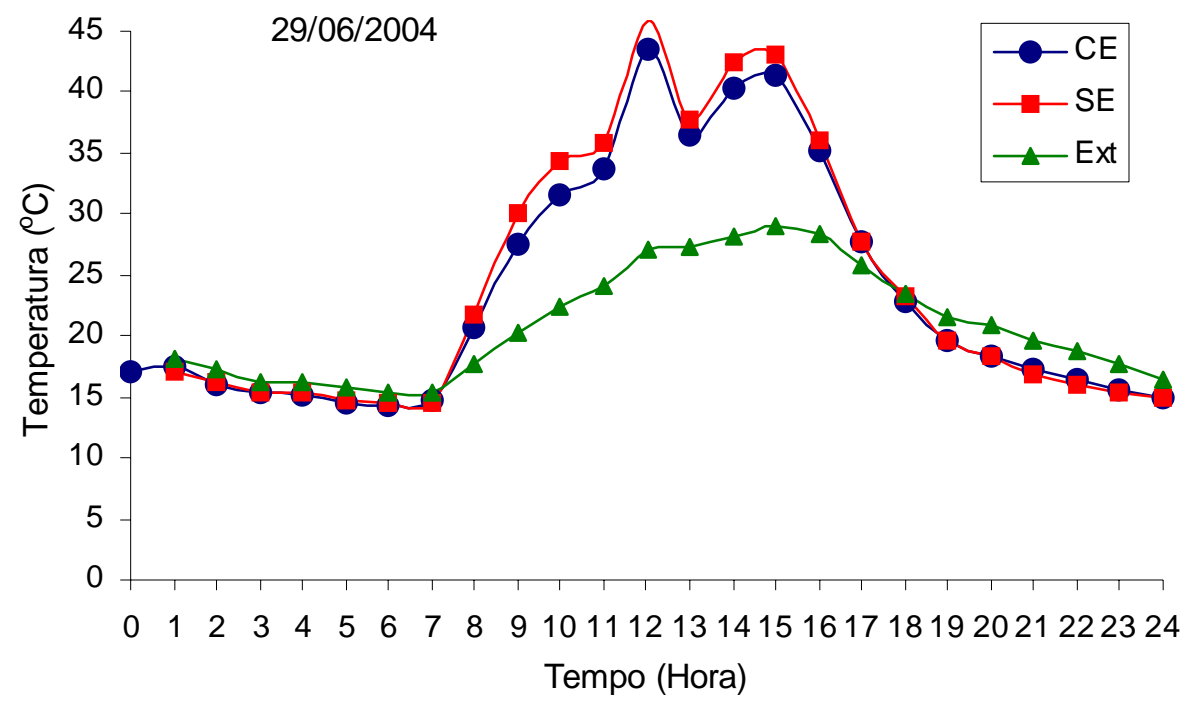

Figura 14-Variação da temperatura do ar nos ambientes protegidos (CE) com exaustor eólico e (SE) sem exaustor e (Ext) no ambiente externo no dia 29/06/04

\subsubsection{Cortinas laterais e frontais abertas com $1,0 \mathrm{~m}$}

Fazendo a abertura com 1m das janelas laterais e frontais dos ambientes protegidos, e mantendo-se abertos os três exaustores eólicos, comparou-se à variação da temperatura média do ar nos dois ambientes no dia 13 de abril de 2004. Neste período ambos ambientes protegidos estavam sendo cultivados com pimentão, e a altura média da cultura de aproximadamente 1m. Na Figura 15, observa-se que ao longo do dia, ocorreu uma pequena variação na temperatura média do ar entre os ambientes protegidos, sendo que a maior diferença foi de $2,9^{\circ} \mathrm{C}$ às $14: 45 \mathrm{~h}$, quando ambiente sem exaustor registrou a sua temperatura máxima de $37,5^{\circ} \mathrm{C}$ e o ambiente com os três exaustores eólicos, registrou a temperatura de $34,6^{\circ} \mathrm{C}$, obtendo uma eficiência de rebaixamento de apenas $7,7 \%$. A temperatura no ambiente externo nessa hora foi de $28,7^{\circ} \mathrm{C}$, ficando o ambiente protegido sem exaustor com temperatura 23,5\% superior a externa e o ambiente protegido com os exaustores eólicos com 17,1\% superior. 


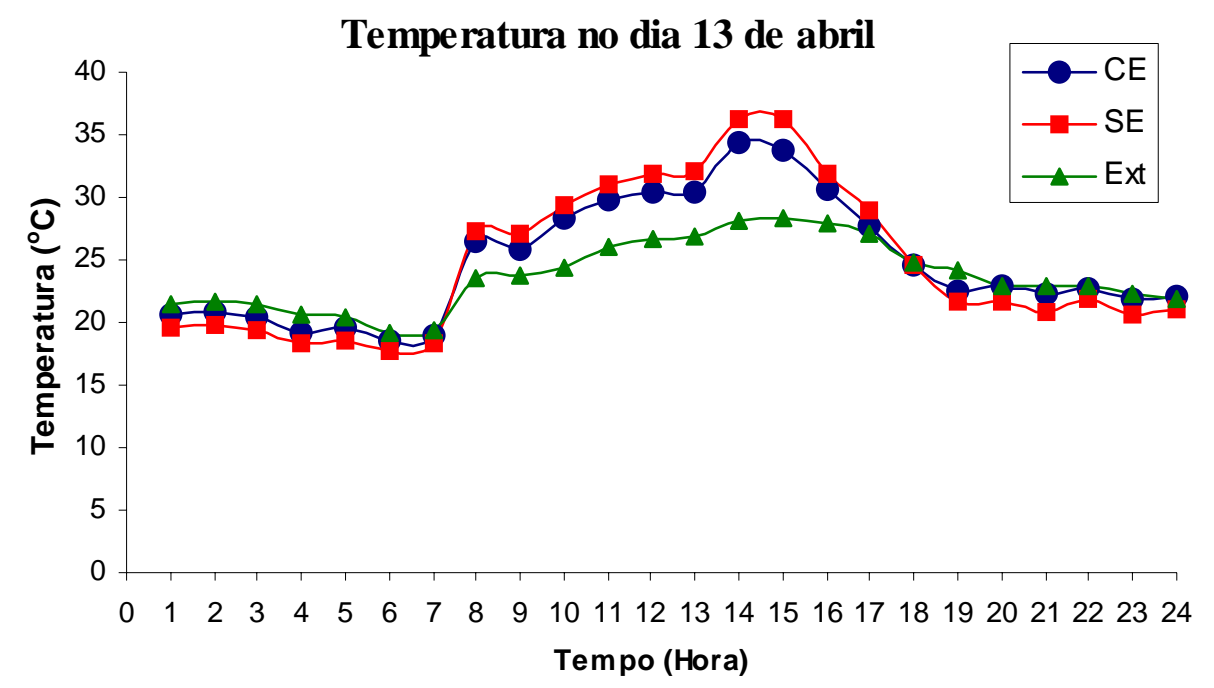

Figura 15-Temperaturas médias obtidas ao longo do dia 13 de abril nos ambientes protegidos cultivados com pimentão, com as cortinas frontais e laterais abertas com $1 \mathrm{~m}$ de altura e os três exaustores eólicos abertos

Na Figura 16, podemos visualizar a distribuição do perfil vertical da temperatura média do ar do dia 13 de abril, no período das 6:00 as 18:00horas, e para 14:45h, horário de temperatura máxima registrada no dia. Observa-se que as médias da temperatura do ar no período diurno no perfil são muito próximas, registrando uma diferença de apenas $1,5^{\circ} \mathrm{C}$, e às $14: 45 \mathrm{~h}$, a maior diferença na temperatura média do perfil, foi de $3,2^{\circ} \mathrm{C}$ registrada na altura de 2,0m da superfície do solo.

Observando os valores das temperaturas no perfil, percebemos que as temperaturas nas alturas de $0,5 \mathrm{~m}$ e $1,0 \mathrm{~m}$, tanto da média do período diurno como a do horário de temperatura mais elevada, estão mais próximas da temperatura do ambiente externo, em função da abertura das cortinas se encontrarem a 1,0m de altura. Após esta altura, os valores das temperaturas começam a aumentar, principalmente no horário das 14:45h, chegando a apresentar uma diferença de aproximadamente $8^{\circ} \mathrm{C}$ da altura de $4,0 \mathrm{~m}$ para a de $1,0 \mathrm{~m}$ no ambiente protegido sem exaustores, e uma diferença de $9^{\circ} \mathrm{C}$ no ambiente com exaustores eólicos. Essa maior diferença no perfil vertical da temperatura no ambiente com exaustores se deve ao fato das temperaturas médias nas alturas de 0,5m 
e $1,0 \mathrm{~m}$ estarem cerca de $3^{\circ} \mathrm{C}$ mais baixas que as médias das temperaturas do ambiente sem exaustores.

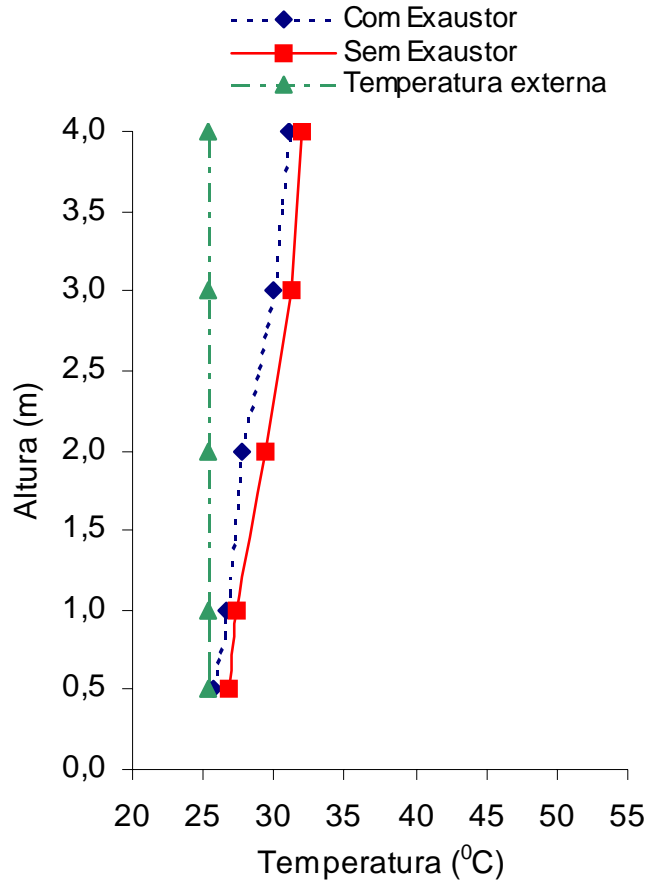

a) Temperatura média das 6:00 - 18:00 horas do dia 13 de abril.

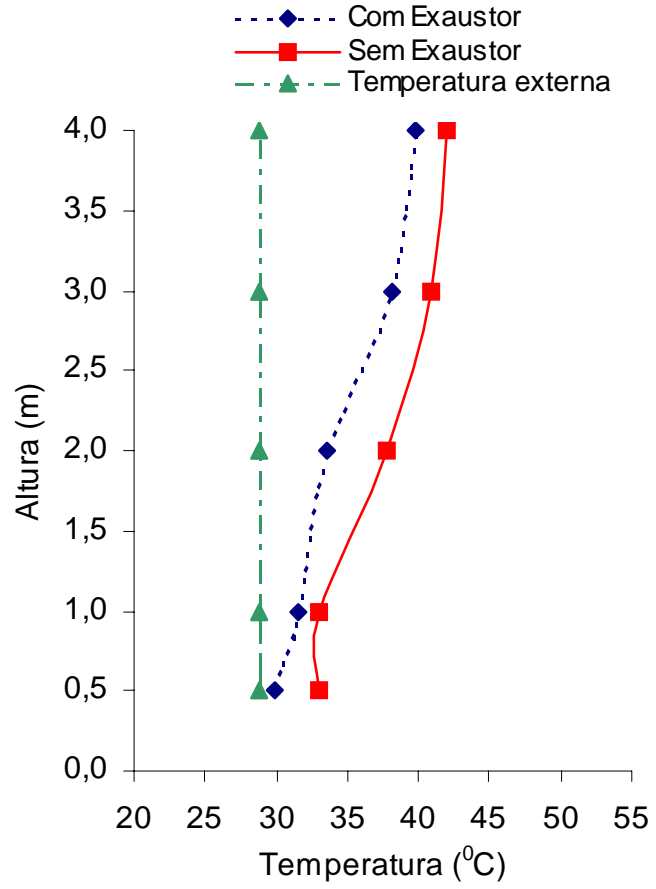

b) Temperatura média as 14:45 horas do dia 13 de abril.

Figura 16-Gráficos das temperaturas médias no dia 13 de abril nas alturas de 0,5m; 1,0m; 2,0m e 3,0m, nos ambientes protegidos cultivados com pimentão, cortinas frontais e laterais abertas com 1m de altura e os três exaustores eólicos abertos para: a) temperaturas médias das 6:00 - 18:00 horas e b) temperaturas médias as 14:45h

As isotermas na Figura 17, traçadas a partir dos valores das temperaturas do ar nos termopares instalados longitudinalmente no centro dos ambientes protegidos, mostram que a distribuição da temperatura fica mais homogênea, e que os fluxos de calor, caminham na direção em que estão localizados os exaustores eólicos. A direção e velocidade do vento no interior dos ambientes protegidos, fatores que influem na redução da temperatura, não foram medidos, mas a velocidade média do vento no 
ambiente externo no período das $6: 00$ às $18: 00 \mathrm{~h}$ foi de $0,72 \mathrm{~m} . \mathrm{s}^{-1}$, e de $1,33 \mathrm{~m} . \mathrm{s}^{-1}$ as 14:45h.

Podemos observar também que o ambiente protegido onde estão instalados os três exaustores eólicos, obtiveram valores menores na temperatura do ar, além da melhor distribuição da temperatura no seu interior, apesar de ambos ambientes protegidos na altura da cultura, conservarem temperaturas dentro da faixa limite aceitável para sua produção.

Também é possível visualizar, a diferença da temperatura do ar demonstrada no perfil vertical que foi determinada com base na média das temperaturas obtidas nos quatro pontos centrais dos ambientes protegidos.

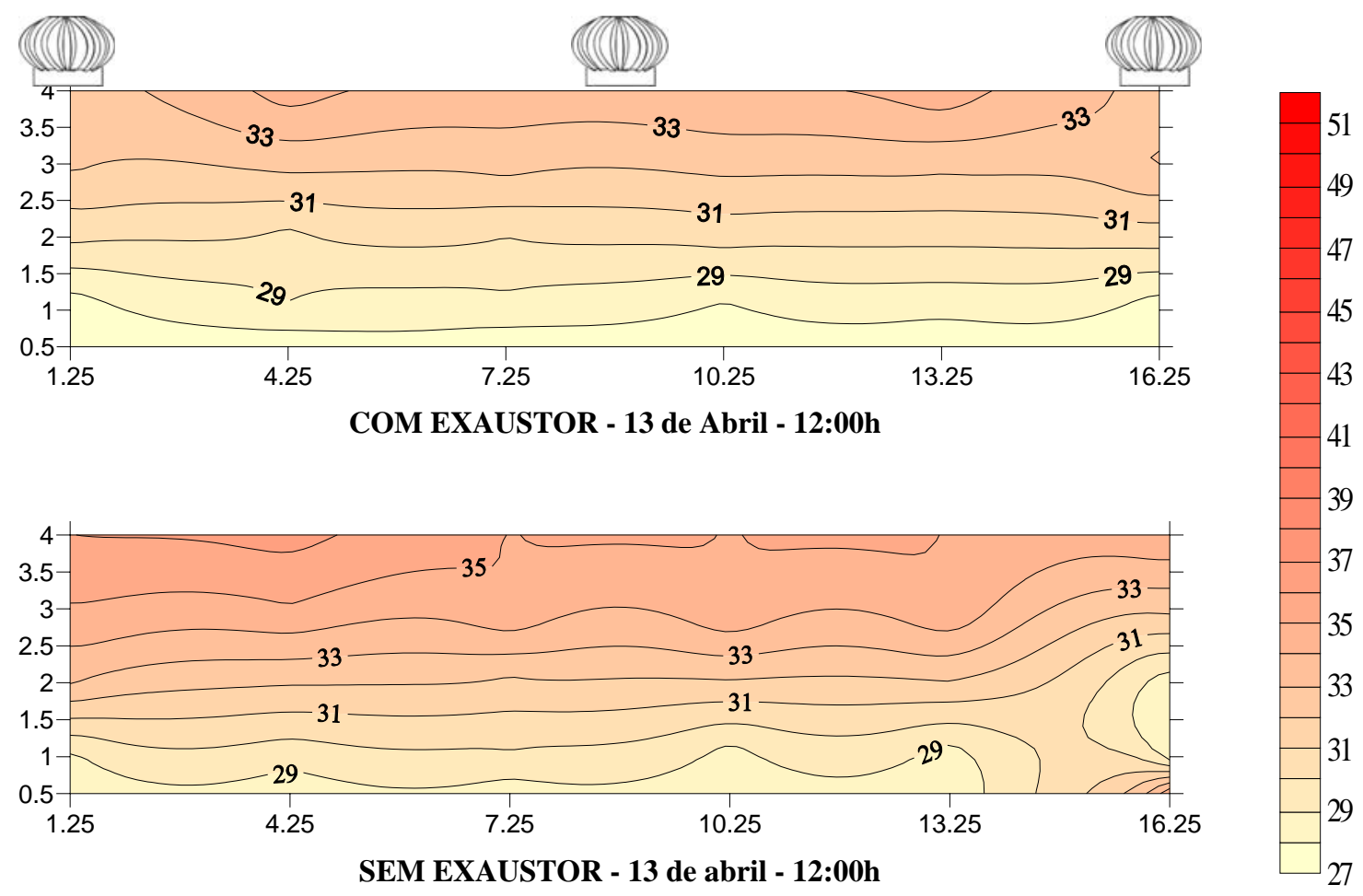

Figura 17-Corte longitudinal do vão central dos ambientes protegidos cultivados com pimentão, com as cortinas frontais e laterais abertas com 1m de altura, as 12:00 horas do dia 13 de abril: a) com os três exaustores eólicos abertos, e b) sem exaustor eólico 
A distribuição da temperatura do ar representando as isotermas obtidas nas alturas de $0,5 \mathrm{~m}, 1,0 \mathrm{~m}, 2,0 \mathrm{~m}$ e 3,0m da superfície do solo, podem ser visualizadas na Figura 18, para os ambientes protegidos com os exaustores eólicos (18a, 18c, 18e, 18g) e para o ambiente sem exaustores (18b, 18d, 18f, 18h).

Nas Figuras 18(a) e 18(b), estão representadas as distribuições horizontais de temperatura do ar na altura de $0,5 \mathrm{~m}$ da superfície do solo. A diferença na distribuição da temperatura do ar no ambiente com exaustores eólicos, foi de apenas $1^{\circ} \mathrm{C}$, enquanto no ambiente sem exaustores, essa diferença chegou a $6^{\circ} \mathrm{C}$, evidenciando a melhor distribuição do gradiente de temperatura nas alturas mais próximas a superfície do solo, devido ao fluxo ascendente da massa de ar quente na direção dos exaustores eólicos.

Nas Figuras 18(c) e 18(d), observamos que as temperaturas estão melhor distribuídas, apresentando em ambos ambientes a diferença de apenas $1^{\circ} \mathrm{C}$ nos dois perfis horizontais, que representam as temperaturas do ar na altura das aberturas das cortinas laterais e frontais dos ambientes.

Embora as temperaturas médias do ar nos dois ambientes sejam muito próximas, a vantagem da utilização dos exaustores eólicos está na melhor distribuição dos gradientes da temperatura nas diferentes alturas no interior do ambiente onde estão instalados, como podemos verificar nas outras alturas apresentadas na Figura 18.

Nas Figuras 18(g) e 18(h), podemos verificar que as diferenças nas temperaturas entre os ambientes, se devem ao fato dos exaustores eólicos facilitarem a saída da massa de ar quente que se forma no teto, tornando homogênea a distribuição do ar nos pontos mais altos, enquanto que no ambiente sem exaustores, essas massas formam bolsões de ar quente que ficam aprisionados junto ao teto, por falta de saídas de ar. 


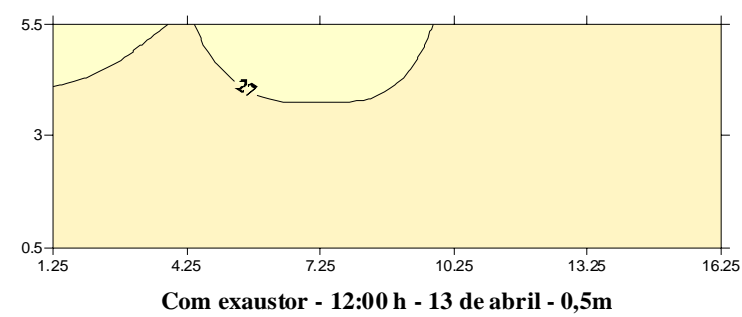

a) com exaustor - altura de $0,5 \mathrm{~m}$

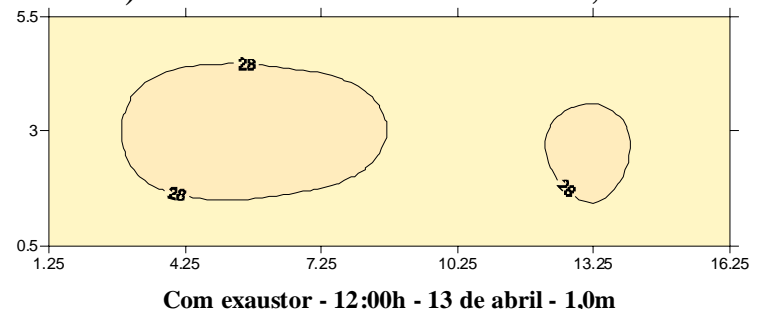

c) com exaustor - altura de $1,0 \mathrm{~m}$

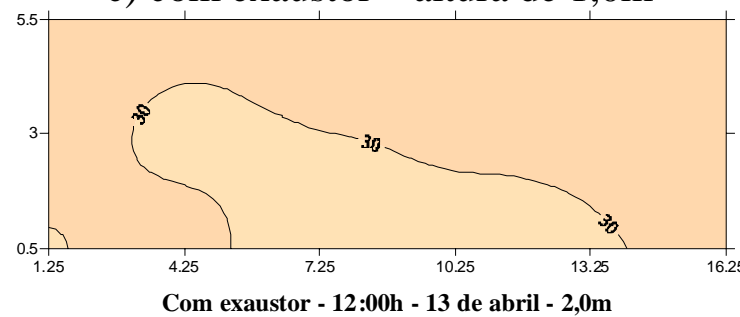

e) com exaustor - altura de 2,0m

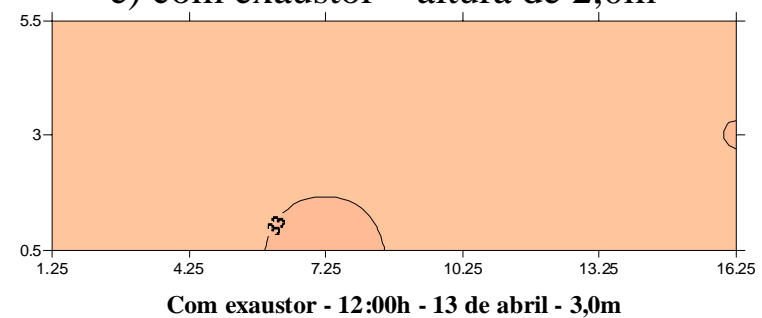

g) com exaustor - altura de 3,0m

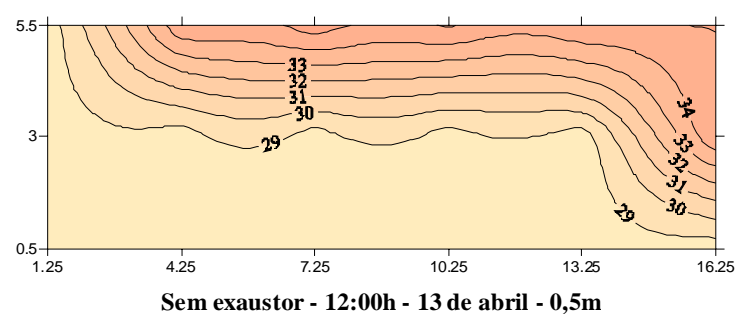

b) sem exaustor - altura de $0,5 \mathrm{~m}$

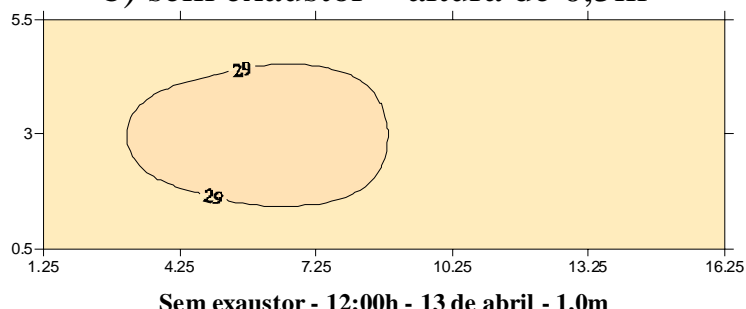

d) sem exaustor - altura de 1,0m

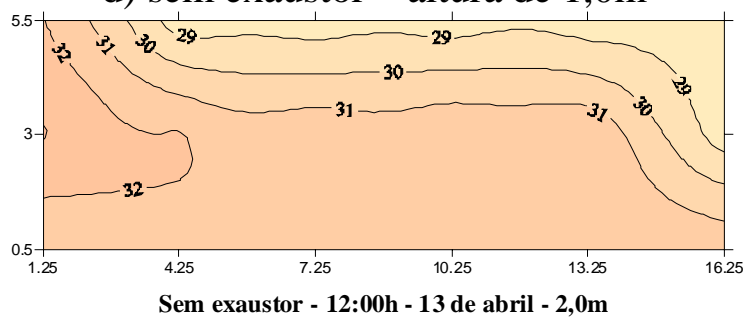

f) sem exaustor - altura de 2,0m

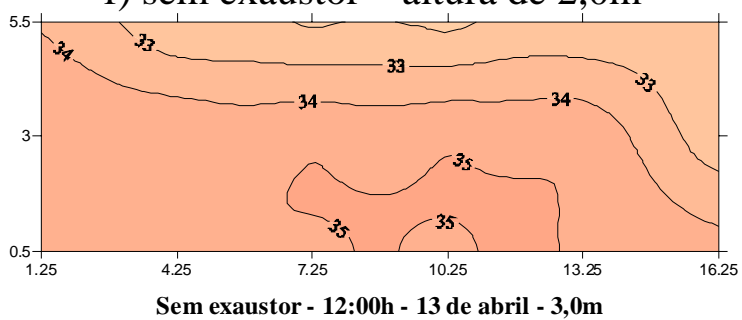

h) sem exaustor - altura de $3,0 \mathrm{~m}$

Figura 18-Cortes das isotermas nas alturas de 0,5m, 1,0m, 2,0m e 3,0m dos ambientes protegidos cultivados com pimentão, com as cortinas frontais e laterais abertas com 1,0m de altura, as 12:00 horas do dia 13 de abril: (a), (c), (e), e (g) com os três exaustores eólicos abertos, e (b), (d), (f), e (h) sem exaustores eólicos

As isotermas determinadas pelos termopares instalados nos seis perfis verticais do ambiente protegido com exaustores eólicos estão representados na Figura19.

Nas Figuras 19(a) e 19(f) o perfil vertical dos cortes 1 e 6, estão exatamente nos locais onde estão instalados exaustores eólicos, e neles podemos visualizar que as isotermas ficam mais espaçadas próximas a cobertura do ambiente, e com temperaturas 
inferiores às encontradas nos perfis que não coincidem com os exaustores, demonstrando que os fluxos de ar quente estão sendo retirados pelas aberturas. Verificase ainda que as isotermas permanecem com uma distribuição uniforme principalmente nas alturas que coincidem com a das aberturas das cortinas.

Nas Figuras 19(b) e 19(d) estão situados a 3m do exaustor mais próximo, e neles podemos visualizar, que à distância entre as isotermas ficam menores e com valores mais altos de temperatura do ar quanto mais próximos da cobertura do ambiente, onde as sucções provocadas pelo s exaustores não conseguem atuar.

Nas Figuras 19(c) e 19 (d) o perfil vertical dos cortes 3 e 4, observa-se que as isotermas apresentam valores um pouco menores pelos efeitos da sucção do exaustor central que está instalado a um raio de $1.5 \mathrm{~m}$ de distancia entre esses cortes.

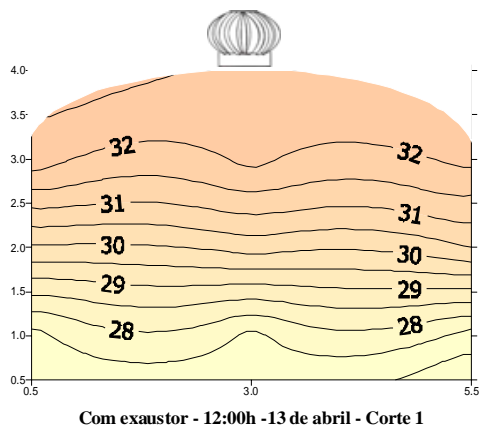

(a) Com exaustor - corte 1

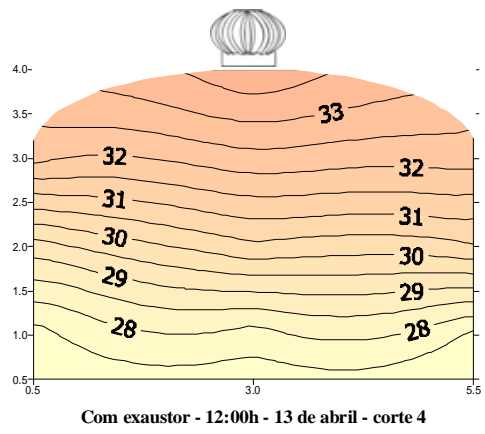

(d) Com exaustor - corte 4

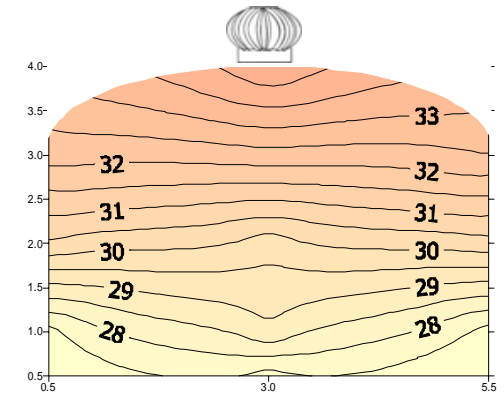

Com exaustor - 12:00h - 13 de abril - corte 2

(b) Com exaustor - corte 2

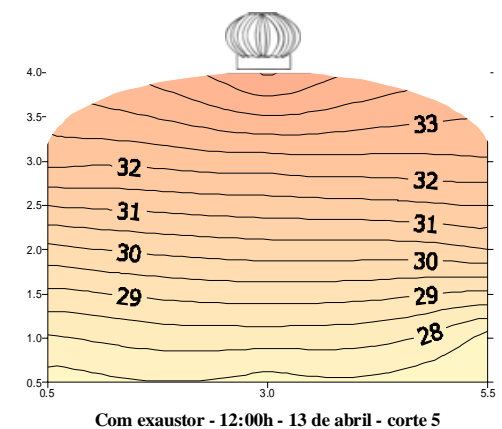

(e) Com exaustor - corte 5

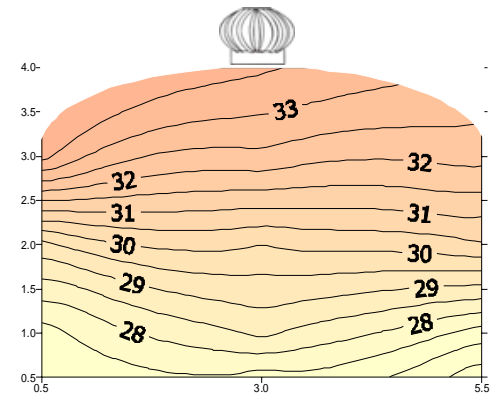

Com exaustor - 12:00h - 13 de abril - corte 3

(c) Com exaustor - corte 3

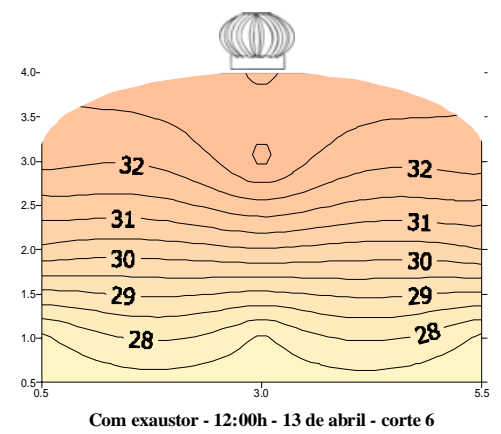

(f) Com exaustor - corte 6

Figura 19-Cortes transversais do ambiente protegido com exaustores eólicos, cultivado com pimentão, com as cortinas frontais e laterais abertas com 1,0m de altura, as 12:00 horas do dia 13 de abril: (a) corte 1; (b) corte 2; (c) corte 3; (d) corte 4; (e) corte 5 e (f) corte 6 
As isotermas determinadas pelos termopares instalados nos seis perfis verticais do ambiente protegido sem exaustores, estão representados na Figura 20.

Nas Figuras 20(a) e 20(d) no perfil vertical dos cortes 1 e 4, verifica-se que a distância entre as isotermas são menores, e a existência de maior concentração de ar quente próximas a cobertura do ambiente.

Nas Figuras 20(b), 20(c), 20(e) e 20(f), que representam os perfis verticais dos cortes 2, 3, 5 e 6, observa-se que as isotermas que representam as temperaturas do ar no ambiente sem exaustor, apresentam bolsas de ar quente entre as massas de ar frio que entram pelas aberturas laterais provocando uma desuniformidade na distribuição das temperaturas do ar no ambiente.

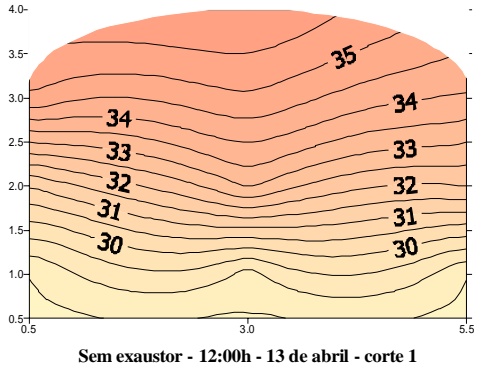

(a) Sem exaustor - corte 1

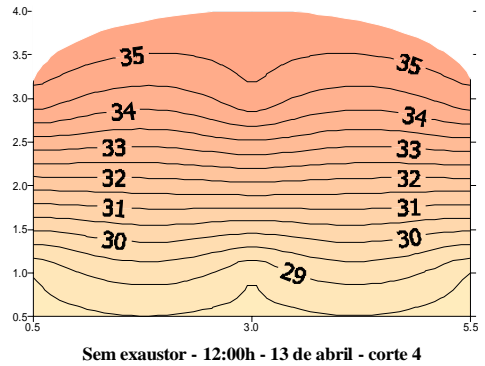

(d) Sem exaustor - corte 4

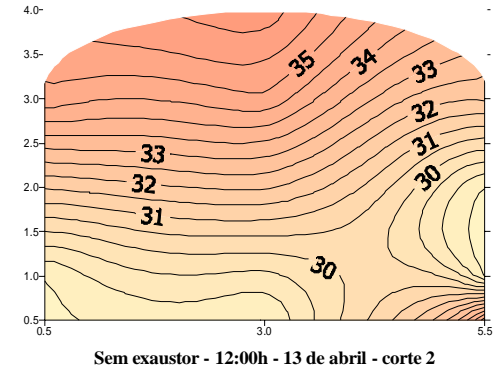

(b) Sem exaustor - corte 2

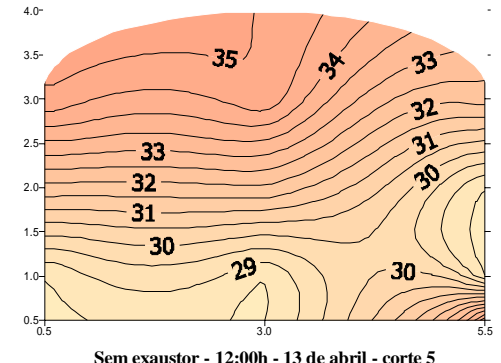

(e) Sem exaustor - corte 5

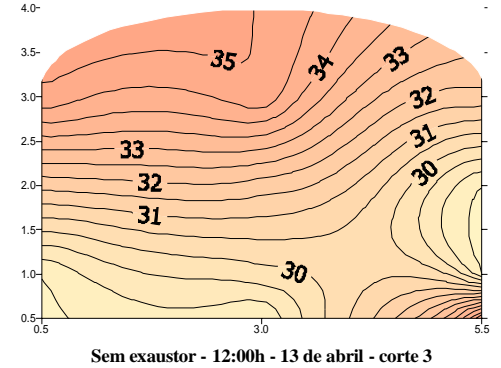

(c) Sem exaustor - corte 3

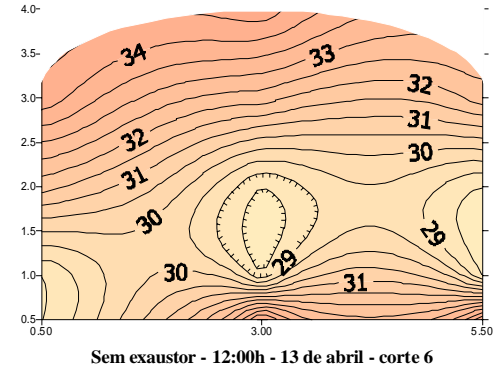

(f) Sem exaustor - corte 6

Figura 20-Cortes transversais do ambiente protegido sem exaustor cultivado com pimentão, com as cortinas frontais e laterais abertas com 1,0m de altura, as 12:00 horas do dia 13 de abril: (a) corte 1; (b) corte 2; (c) corte 3; (d) corte 4; (e) corte 5 e (f) corte 6 


\subsubsection{Cortinas laterais abertas $\operatorname{com} 1,0 \mathrm{~m}$ e cortinas frontais totalmente fechadas.}

Fazendo o fechamento total das janelas frontais, e mantendo a abertura das janelas laterais com 1,0m de altura nos dois ambientes protegidos, e mantidos abertos os três exaustores eólicos, comparamos à variação da temperatura média do ar nos dois ambientes no dia 17 de maio de 2004. Os ambientes protegidos ainda estavam sendo cultivados com pimentão, e a altura média da cultura era aproximadamente 1,2m.

Na Figura 21, verifica-se que a temperatura média do ar no decorrer do dia, no ambiente protegido com exaustores eólicos é um pouco mais baixa que o ambiente sem exaustores, ficando aproximadamente $3,1^{\circ} \mathrm{C}$ menor as $13: 30 \mathrm{~h}$, horário de maior temperatura no dia, o que representa uma eficiência de rebaixamento de temperatura de 8,9\%. A temperatura no ambiente externo nessa hora foi de $22^{\circ} \mathrm{C}$, ficando o ambiente protegido sem exaustor com temperatura 62,5\% superior a externa e o ambiente protegido com os exaustores eólicos com 48,3\% superior.

Ainda na Figura 21, observa-se que nos períodos noturnos em que os ambientes eram mantidos abertos, as temperaturas médias do ambiente sem exaustor a partir das 0:00h até as 6:45h foram menores que as médias do ambiente externo, caracterizando a ocorrência de inversão térmica, enquanto as temperaturas médias do ambiente com exaustores permaneceram iguais ou maiores que as temperaturas externas. No horário de temperatura mais baixa, que foi as 6:45h, a média da temperatura do ar externa era $6,7^{\circ} \mathrm{C}$ enquanto a média das temperaturas dos ambientes protegida era: na sem exaustor $5,1^{\circ} \mathrm{C}$ e na com exaustor $7,5^{\circ} \mathrm{C}$, ficando o ambiente sem exaustor com a temperatura média $24 \%$ inferior e o ambiente com exaustores $12 \%$ superior a temperatura externa. 


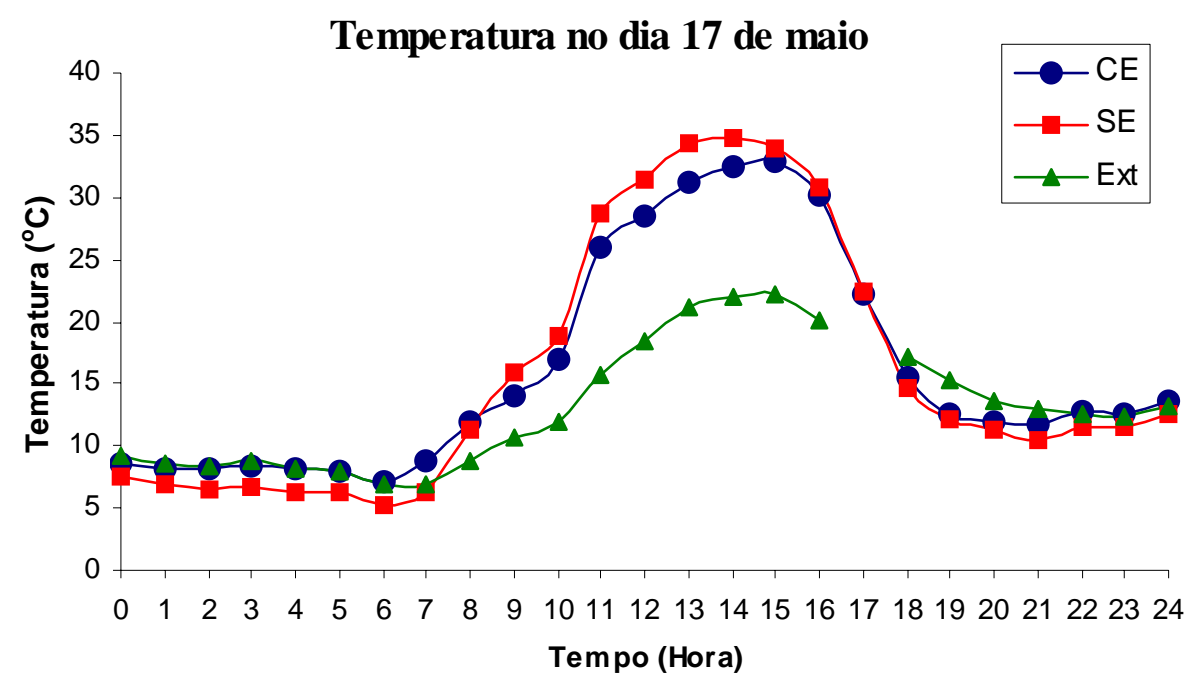

Figura 21-Temperaturas médias obtidas ao longo do dia 17 de maio, com as estufas com cultura de pimentão, com as cortinas frontais totalmente fechadas, as cortinas laterais abertas com $1 \mathrm{~m}$ de altura e apenas o exaustor eólico central aberto

Na Figura 22(a), visualiza-se a distribuição do perfil vertical da temperatura média do ar no dia 17 de maio, no período das 0:00 as 6:00horas. Observa-se que durante a noite, as médias da temperatura do ar do ambiente externo e a do ambiente protegido com exaustores, são muito próximas, registrando uma diferença de aproximadamente $0,3^{\circ} \mathrm{C}$, e que as médias do ambiente protegido sem exaustores, ficaram quase $2^{\circ} \mathrm{C}$ abaixo do ambiente externo.

Na Figura 22(b), verifica-se que, as 6:45h horário de temperatura mais baixa registrada no dia, a distribuição do perfil vertical da temperatura média do ar apresentou as médias da temperatura do ar do ambiente protegido superiores as do ambiente externo, sendo que a média da temperatura do ar foi superior em 15\% a temperatura média externa. As médias do perfil vertical do ambiente sem exaustores, apresentou temperaturas médias inferiores a do ambiente externo, com a média da temperatura do ar inferior em $23,5 \%$. 


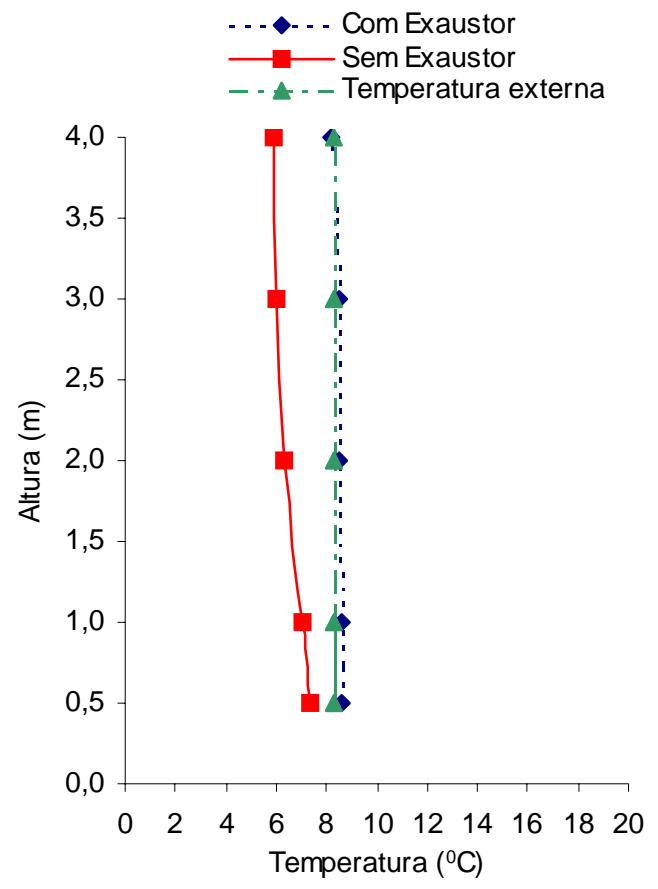

(a) Temperatura média das 0-6:00 horas do dia 17 de maio.

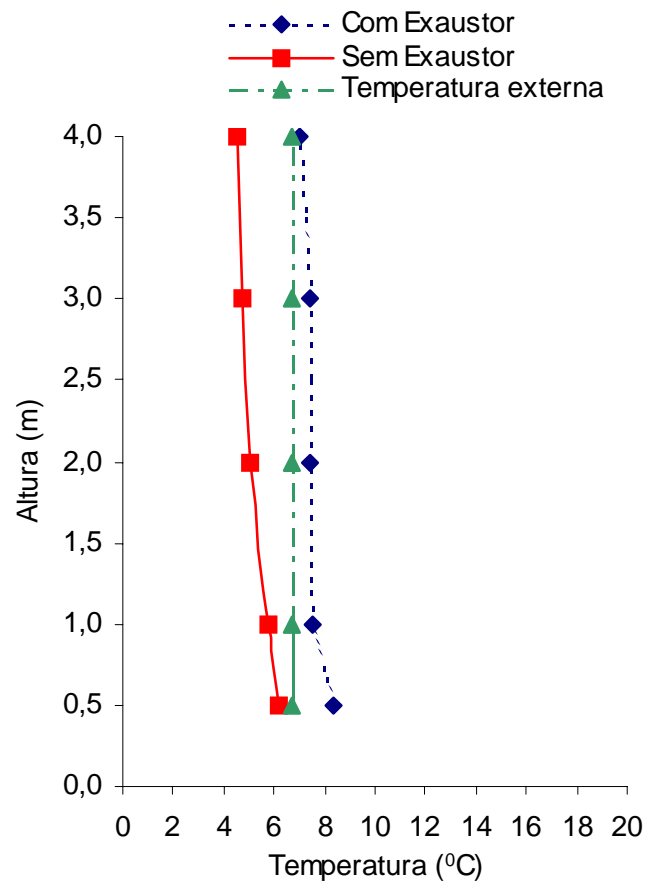

(b) Temperatura média as 6:45 horas do dia 17 de maio.

Figura 22-Gráficos das temperaturas médias no dia 17 de maio nas alturas de 0,5m; 1,0m; 2,0m e 3,0m, para: (a) temperaturas médias das 0-6:00 horas e (b) temperaturas médias as 6:45 horas

Na Figura 23, as isotermas traçadas a partir dos valores das temperaturas do ar nos termopares instalados longitudinalmente no centro dos ambientes protegidos, mostram que a sucção provocada pelos exaustores eólicos direciona o fluxo de calor que é desprendido do solo, no sentido dos exaustores, melhorando a distribuição da temperatura, e provocando o aquecimento mais uniforme do ambiente, em comparação com a distribuição da temperatura no ambiente protegido sem exaustor. 


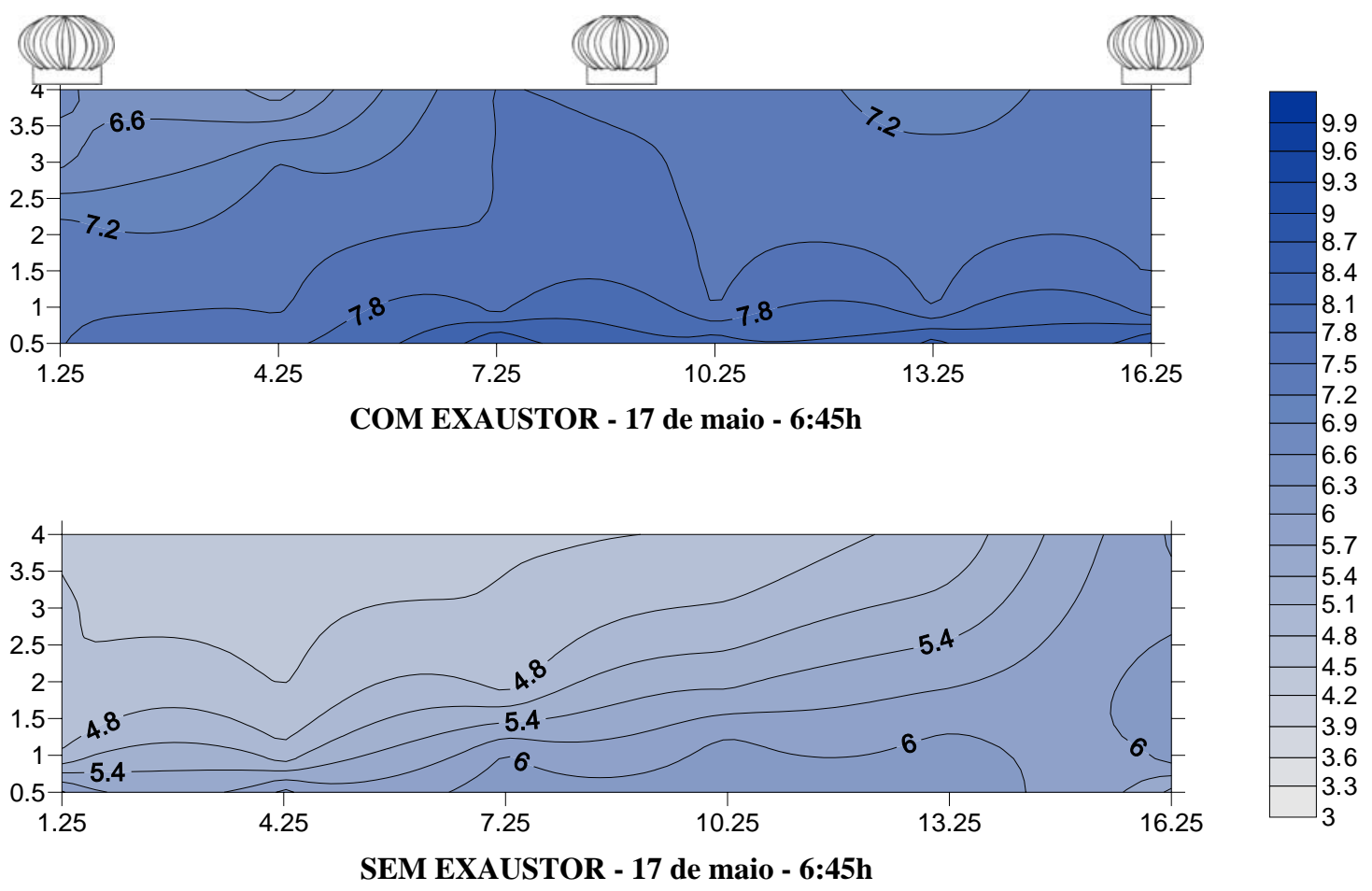

Figura 23-Corte longitudinal do vão central dos ambientes protegidos cultivados com pimentão, com as cortinas frontais fechadas e as cortinas laterais abertas com 1m de altura: a) com apenas o exaustor eólico central aberto, e b) sem exaustor eólico, as 6:45h do dia 17 de maio

Na Figura 24(a) e 24(b), estão representadas as distribuições horizontais de temperatura do ar na altura de 0,5m da superfície do solo. Observa-se na faixa central dos ambientes protegidos o fluxo de calor desprendido pelo solo e nas laterais dos ambientes a entrada das massas de ar frio através das cortinas laterais que estão abertas.

Nas Figuras 24(c), 24(e) e 24(g), observa-se o deslocamento do ar quente no sentido vertical para cima e para o centro da cobertura, tornando mais homogênea a distribuição da temperatura no ambiente com exaustor.

Nas Figuras 24(d), 24(f) e 24(h), verifica-se o efeito contrário, onde as massas de ar frio que entram pelas aberturas laterais e do ar que é resfriado pela cobertura plástica 
que reveste o teto, provocam a redução da temperatura no interior do ambiente protegido sem exaustor eólico.
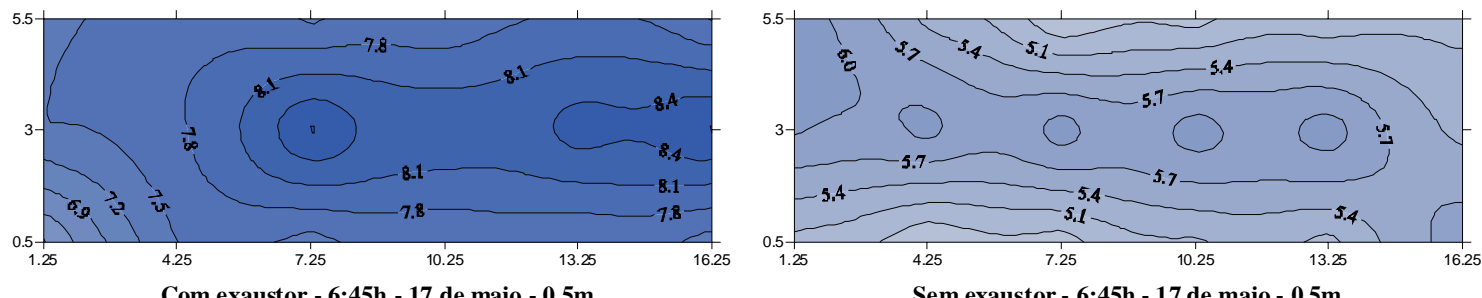

a) com exaustor - altura de $0,5 \mathrm{~m}$

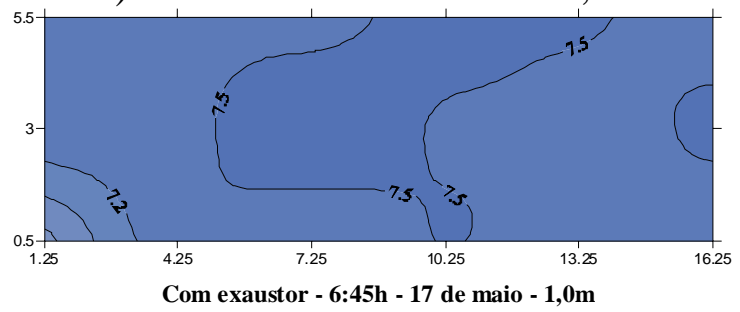

b) sem exaustor - altura de $0,5 \mathrm{~m}$

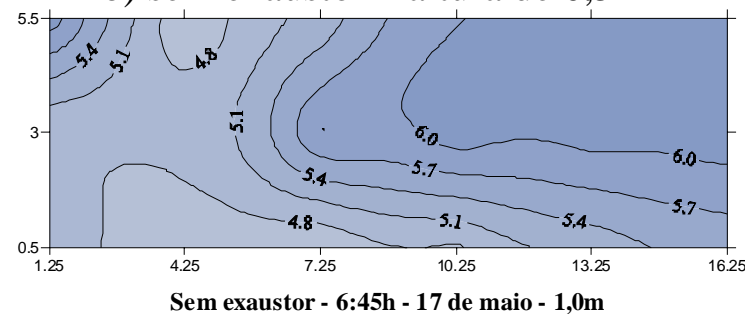

c) com exaustor - altura de $1,0 \mathrm{~m}$

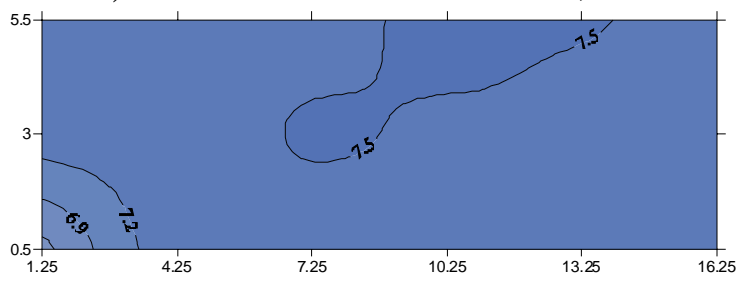

Com exaustor - $6: 45 \mathrm{~h}$ - 17 de maio - $2,0 \mathrm{~m}$

e) com exaustor - altura de 2,0m

d) sem exaustor - altura de 1,0m

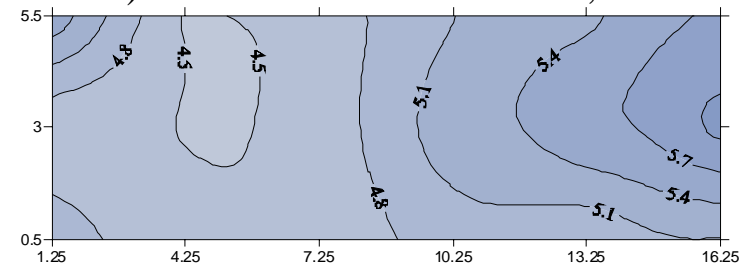

Sem exaustor - 6:45h - 17 de maio - 2,0m

f) sem exaustor - altura de 2,0m

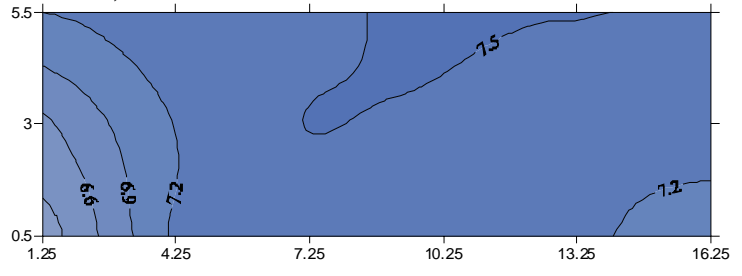

Com exaustor - 6:45h - 17 de maio - 3,0m

g) com exaustor - altura de 3,0m

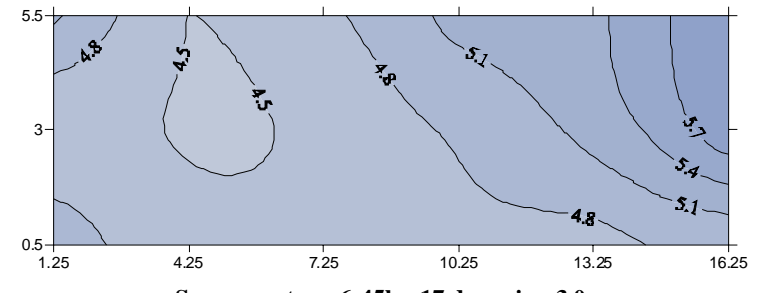

Sem exaustor - 6:45h - 17 de maio - 3,0m

h) sem exaustor - altura de 3,0m

Figura 24-Cortes das isotermas nas alturas de 0,5, 1,0, 2,0 e 3,0 metros dos ambientes protegidos: a), c), e), e g) com apenas o exaustor eólico central aberto, e b), d), f), e h) sem exaustor eólico, as 6:45h do dia 17 de maio

A sucção dos exaustores eólicos facilita a retirada do ar quente que se acumula na parte superior do ambiente provocando o deslocamento do fluxo de calor desprendido pelo solo no sentido vertical em sua direção, fazendo com que o ar quente se distribua mais facilmente no seu interior, enquanto no ambiente sem exaustores essas massas 
formam bolsões de ar quente que ficam aprisionados junto ao teto, por falta de saídas de ar, e vão se resfriando em contato com os plásticos que revestem a cobertura. Esses efeitos podem ser visualizados na Figura 25.

Na Figura 25(a) o perfil vertical dos cortes 1, local onde está instalado o exaustor eólico, podemos visualizar que as isotermas evidenciam a influência da massa de ar frio que se desloca no sentido sudoeste, provocando as temperaturas mais baixas no lado esquerdo da figura. Percebe-se também o fluxo de ar quente que sai do solo no centro do ambiente, em direção a base do exaustor eólico, fato que se repete nas figuras 25(b), 25(d), 25(e) 25(f), e com maior intensidade na figura 25(c) onde o fluxo de calor descreve um caminho direto até a cobertura do ambiente protegido com exaustores eólicos.

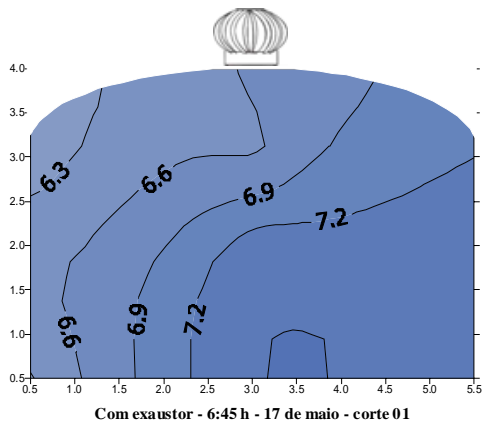

a)com exaustor - corte 1

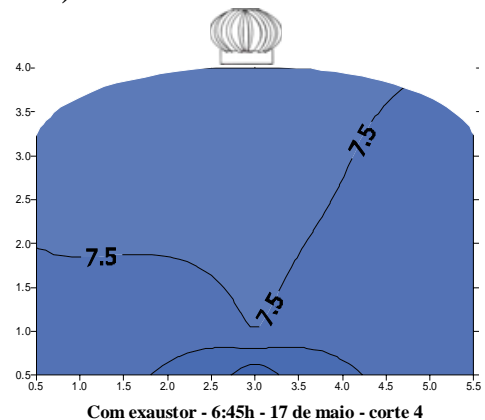

(d)com exaustor - corte 4

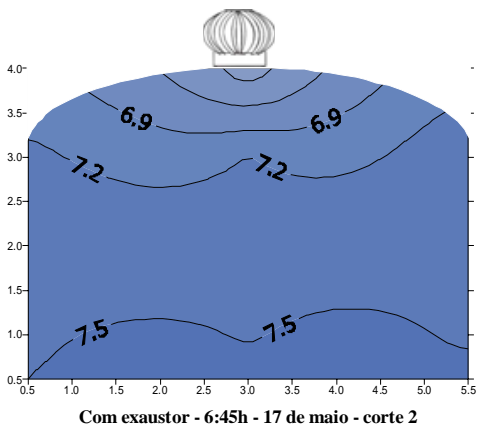

b)com exaustor - corte 2

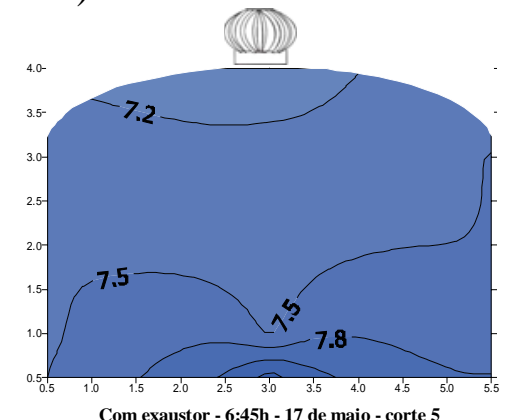

(e)com exaustor - corte 5

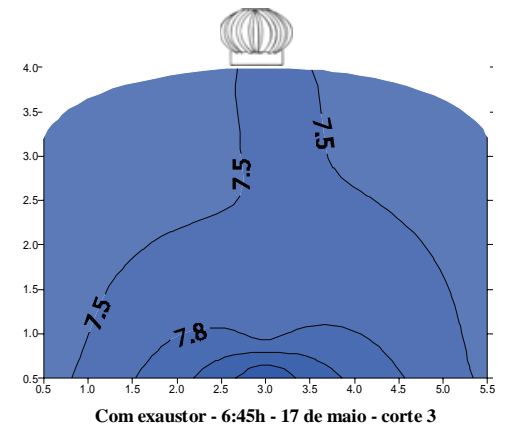

c) com exaustor - corte 3

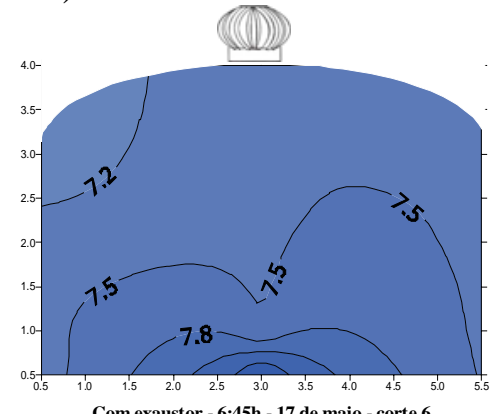

(f) com exaustor - corte 6

Figura 25-Cortes transversais do ambiente protegido com exaustores eólicos, cultivado com pimentão, com as cortinas frontais fechadas e as laterais abertas com 1,0m de altura, as 6:45h do dia 17 de maio: (a) corte 1; (b) corte 2; (c) corte 3; (d) corte 4; (e) corte 5 e (f) corte 6 
Nas Figuras 26(a), 26(b), 26(c), 26(d) e 26(e) que representam os perfis verticais dos cortes $1,2,3$, 4, e 5, observa-se que as isotermas que representam as temperaturas do ar no ambiente, demonstram o efeito das massas de ar frio que são formadas na cobertura plástica do ambiente, e se locomovem no sentido vertical, de cima para baixo, comprimindo e interferindo nos fluxos de ar quente que tenderiam a atingir a cobertura do ambiente.

Na Figura 26(f), que representa o perfil vertical do corte 6, observa-se que as isotermas que representam as temperaturas do ar no ambiente sem exaustor, apresentam um fluxo de ar quente se dirigindo a cobertura, e uma entrada de massa de ar frio no sentido lateral da esquerda para a direita, deslocando o fluxo de ar quente para a lateral direita do ambiente protegido.

No ambiente protegido sem exaustor, as temperaturas do ar apresentaram médias no interior, entre 4,5 e $6,0^{\circ} \mathrm{C}$, enquanto a temperatura no ambiente externo era de $6,7^{\circ} \mathrm{C}$.

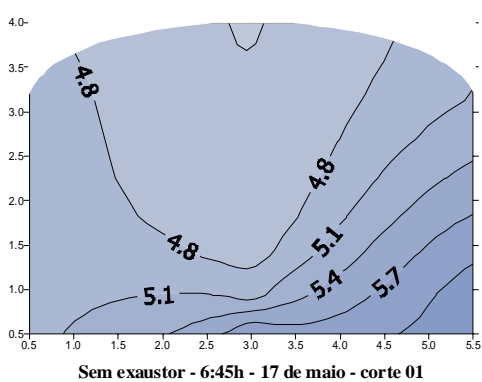

(a) Sem exaustor - corte 1

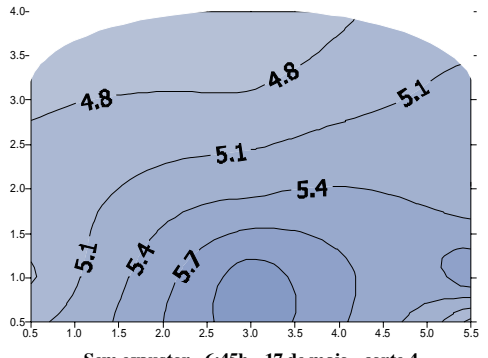

(d) Sem exaustor - corte 4

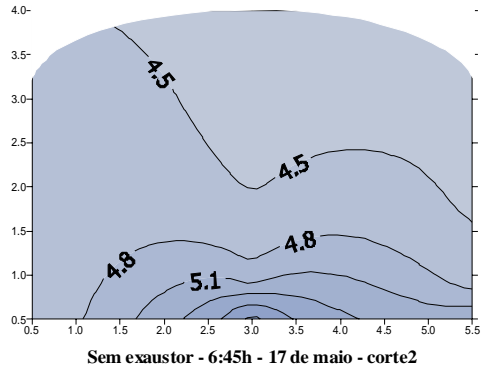

(b) Sem exaustor - corte 2

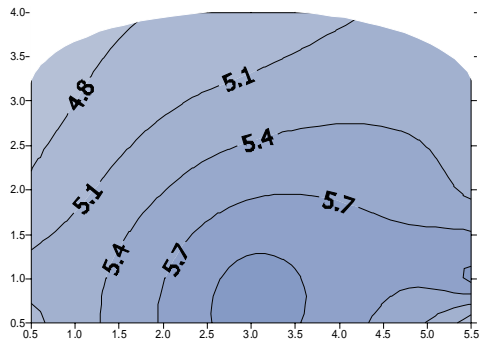

(e) Sem exaustor - corte 5

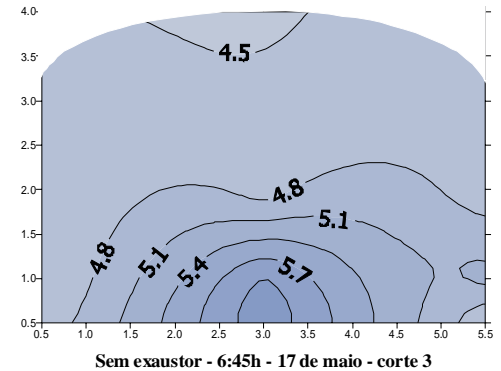

(c) Sem exaustor - corte 3

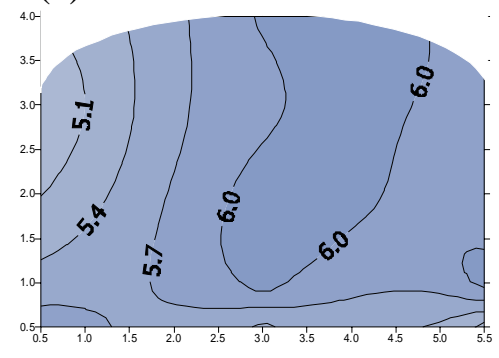

Sem exaustor - 6:45h - 17 de maio - corte 6

(f) Sem exaustor - corte 6

Figura 26-Cortes transversais do ambiente protegido sem exaustor, cultivado com pimentão, com as cortinas frontais fechadas e laterais abertas com 1,0m de altura, as 6:45h do dia 17 de maio: (a) corte 1; (b) corte 2; (c) corte 3; (d) corte 4; (e) corte 5 e (f) corte 6 


\subsubsection{Cortinas laterais totalmente fechadas e cortinas frontais abertas com $1,0 \mathrm{~m}$.}

Fazendo o fechamento total das janelas laterais, e mantendo a abertura das janelas frontais com 1,0m de altura nos dois ambientes protegidos, e mantidos abertos os três exaustores eólicos, comparamos à variação da temperatura média do ar nos dois ambientes no dia 14 de junho de 2004. Os ambientes protegidos estão sem cultura.

Na Figura 27, verifica-se que a temperatura média do ar no decorrer do dia, no ambiente protegido com exaustores eólicos é apenas $2,0^{\circ} \mathrm{C}$ mais baixa que o ambiente sem exaustores as 14:00 horas, horário de maior temperatura no dia, o que representa uma eficiência de rebaixamento de temperatura de 5,5\%. A temperatura no ambiente externo nessa hora foi de $23,7^{\circ} \mathrm{C}$, ficando o ambiente protegido sem exaustor com temperatura $62,7 \%$ superior a externa e o ambiente protegido com os exaustores eólicos com $54,0 \%$ superior.

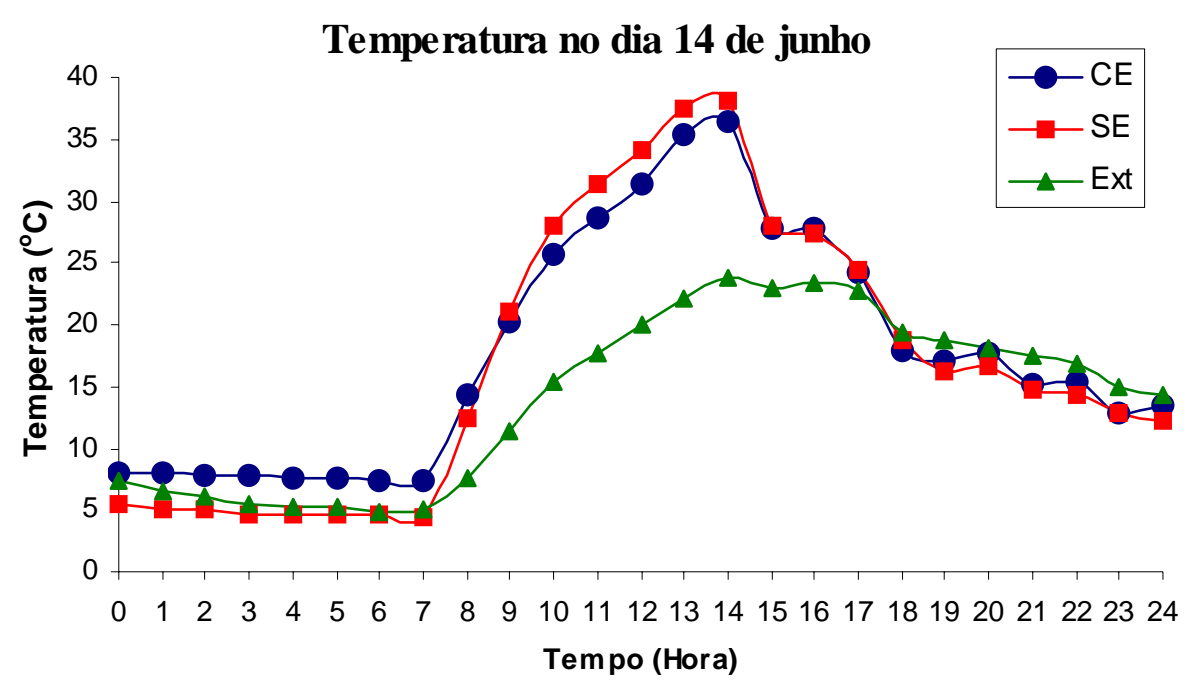

Figura 27-Temperaturas médias obtidas ao longo do dia 14 de junho, com as estufas sem cultura, com as cortinas laterais totalmente fechadas e as cortinas frontais abertas com $1 \mathrm{~m}$ de altura e apenas o exaustor eólico central aberto

Ainda na Figura 27, observa-se que nesta noite que foi a noite mais fria do período, e que os ambientes foram mantidos abertos, as temperaturas médias do ambiente sem exaustor a partir das 0:00h até as $6: 00 \mathrm{~h}$ foram $1,5^{\circ} \mathrm{C}$ ou $24 \%$ menor que as 
médias do ambiente externo, caracterizando a ocorrência de inversão térmica, enquanto as temperaturas médias do ambiente com exaustores permaneceram $2^{\circ} \mathrm{C}$ ou $34,5 \%$ maior que as temperaturas externas. No horário de temperatura mais baixa, que foi as 6:45h, a média da temperatura do ar externa era $4,9^{\circ} \mathrm{C}$ enquanto a média das temperaturas dos ambientes protegida era: na sem exaustor $4,5^{\circ} \mathrm{C}$ e na com exaustor $7,4^{\circ} \mathrm{C}$, ficando o ambiente sem exaustor com a temperatura média 8\% inferior e o ambiente com exaustores $51 \%$ superior a temperatura externa.

Na Figura 28(a) e 28(b), visualiza-se a distribuição do perfil vertical da temperatura média do ar no dia 14 de junho, no período das 0:00 as 6:00horas.

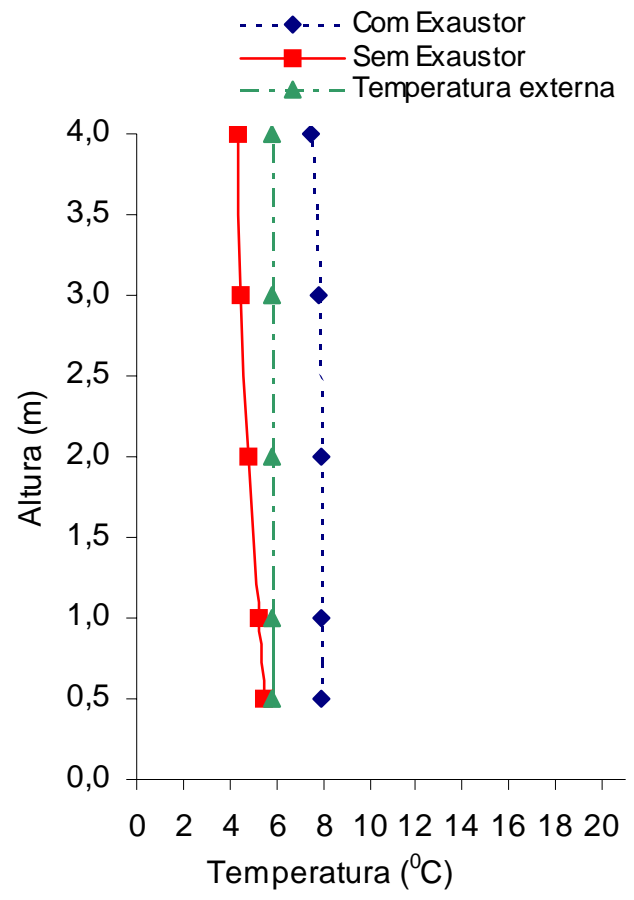

a) Temperatura média das 0-6:00 horas do b) Temperatura média as 6:45 horas do dia 14 de junho.

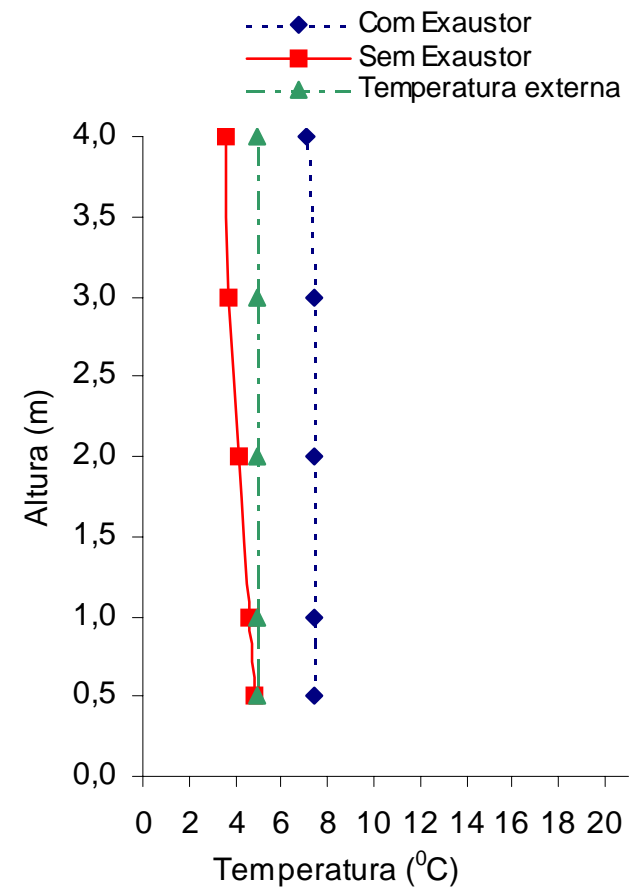
dia 06 de junho.

Figura 28-Gráficos das temperaturas médias dos ambientes protegidos sem cultura, com as cortinas laterais fechadas e as frontais abertas com 1,0m de altura, no dia 14 de junho nas alturas de $0,5 \mathrm{~m} ; 1,0 \mathrm{~m} ; 2,0 \mathrm{~m}$ e 3,0m, para: a) temperaturas médias das 0-6:00 horas e b) temperaturas médias as 6:45 horas 
Na Figura 29, as isotermas traçadas a partir dos valores das temperaturas do ar nos termopares instalados longitudinalmente no centro dos ambientes protegidos, mostram que mesmo com apenas as cortinas frontais abertas com 1,0m de altura, a distribuição da temperatura no interior do ambiente protegido com exaustores eólicos é mais homogênea, e a perda de calor para a ventilação é menor, provocando o aquecimento mais uniforme do ambiente, em comparação com a distribuição da temperatura no ambiente protegido sem exaustor. Podemos ainda visualizar, que as massas de ar frio estão concentradas na parte superior e no sentido oeste dos ambientes protegidos.

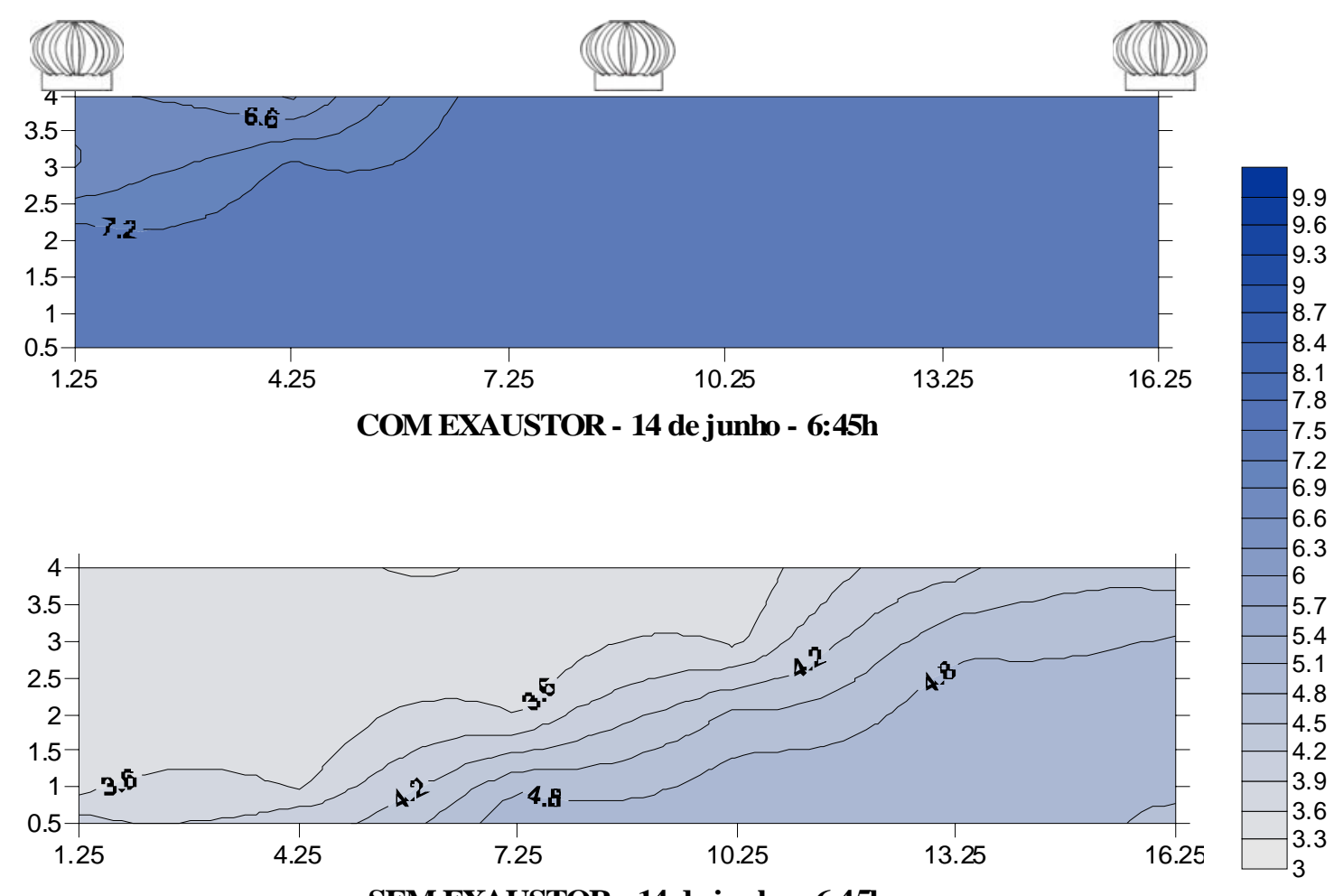

Figura 29-Corte longitudinal do vão central dos ambientes protegidos sem cultura, com as cortinas laterais fechadas e as frontais abertas com 1,0m de altura: a) com apenas o exaustor eólico central aberto, e b) sem exaustor eólico, as 6:45h do dia 14 de junho, no horário de temperatura mais baixa 
Na Figura 30 estão representadas as distribuições horizontais de temperatura do ar nas alturas de 0,5m, 1,0m, 2,0m e 3,0m da superfície do solo. Observa-se que no ambiente protegido com exaustores eólicos Figura 28(a), o fluxo de calor desprendido pelo solo é distribuído uniformemente por toda área, sendo que em apenas um pequeno canto no lado sul sudoeste, apresenta um gradiente na temperatura do ar, variando entre 6,3 e 7,2 ${ }^{\circ} \mathrm{C}$, enquanto no ambiente protegido sem exaustores Figura 28(b), podemos visualizar bolsões de ar quente misturados com massa de ar frio principalmente nos lados sul e oeste do ambiente, e no lado sudeste o predomínio é das temperaturas mais elevadas. A temperatura média do ar no ambiente variou de 3,6 a 5, $1^{\circ} \mathrm{C}$, ficando bem abaixo do outro ambiente.

Nas Figuras 30(c) e 30(e) a distribuição horizontal de temperatura média do ar no ambiente protegido com exaustores eólicos, seguiu a mesma tendência da ocorrida a 0,5m, porém com temperaturas um pouco mais elevadas predominando no sentido norte do ambiente. A temperatura mais baixa ficou limitada apenas em um canto no lado sulsudoeste do ambiente. A temperatura média do ar no ambiente protegido variou de $6,3^{\circ} \mathrm{C}$ até $7,2^{\circ} \mathrm{C}$.

Na Figura 30(g), observa-se que as temperaturas do ar na altura de 3,0m estão mais elevadas que as alturas abaixo, e que o fluxo de calor desprendido do solo está deslocando a massa de ar frio no sentido sudoeste do ambiente.

Nas Figuras 30(d), 30(f), e 30(h), verifica-se que o sentido do gradiente da temperatura do ar no interior do ambiente é o mesmo, com a massa de ar frio caminhando no sentido sul-norte, reduzindo a temperatura no sentido vertical, da cobertura para a superfície do solo, empurrando o fluxo de calor liberado pelo solo para o lado nordeste do ambiente. As massas de ar frio predominam em todas as alturas, o que mantém a temperatura bem mais baixa que o outro ambiente. A temperatura média do ar no ambiente protegido sem exaustor variou de $3,3^{\circ}$ a $4,8^{\circ} \mathrm{C}$, demonstrando que na parte mais alta, as temperaturas estão mais baixas. 


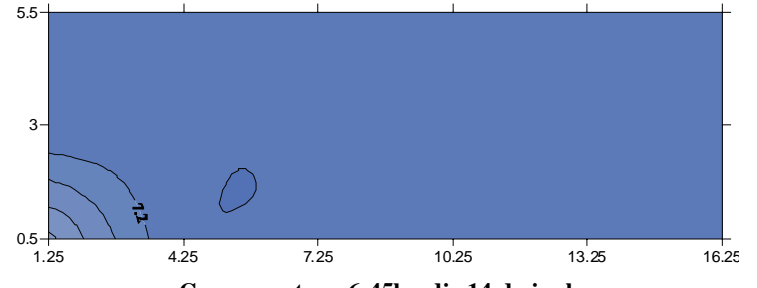

Com exaustor - 6:45h - dia 14 de junho

a) com exaustor - altura de $0,5 \mathrm{~m}$

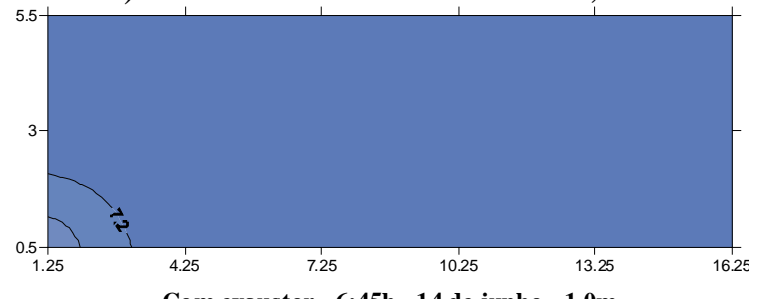

Com exaustor - 6:45h - 14 de junho - 1,0m

c) com exaustor - altura de $1,0 \mathrm{~m}$

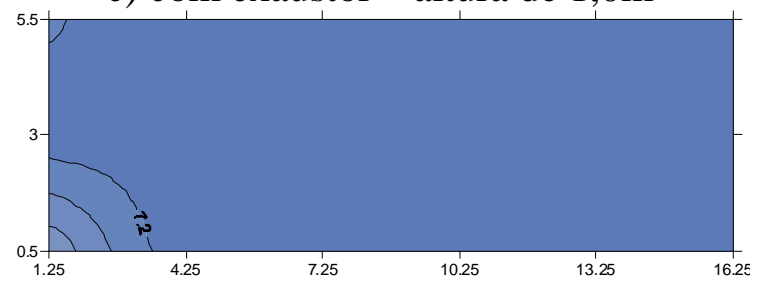

Com exaustor - 6:45h - 14 de junho - 2,0m

e) com exaustor - altura de 2,0m

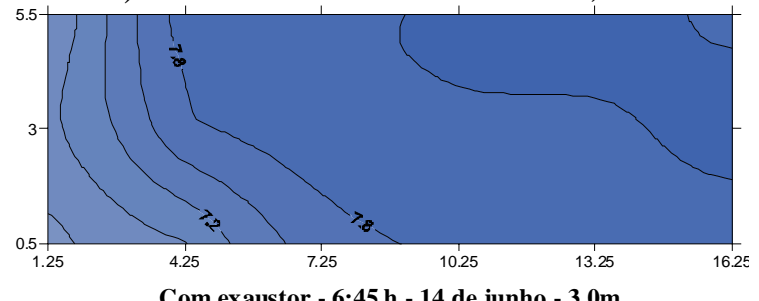

g) com exaustor - altura de $3,0 \mathrm{~m}$

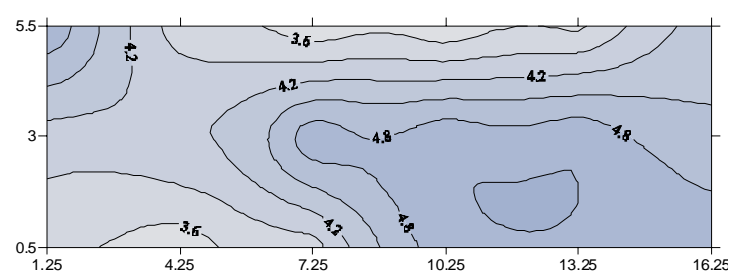

Sem exaustor - 6:45h - dia 14 de junho.

b) sem exaustor - altura de $0,5 \mathrm{~m}$

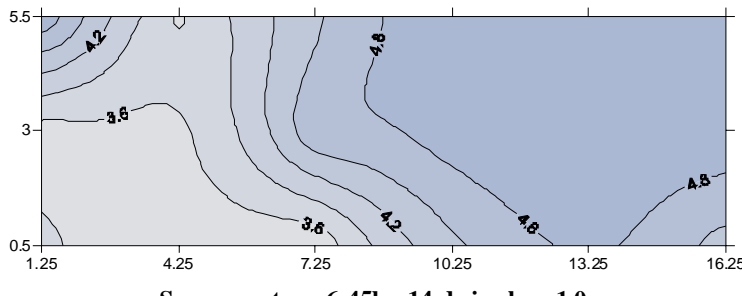

d) sem exaustor - altura de $1,0 \mathrm{~m}$

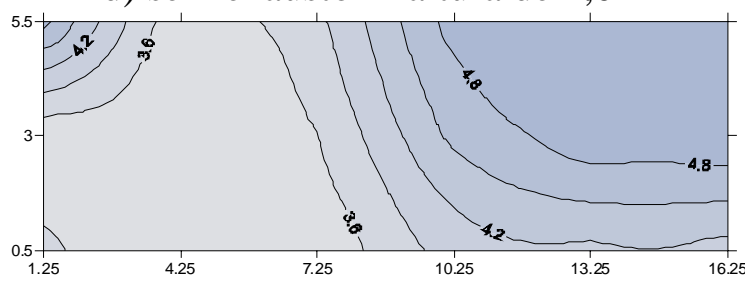

Sem exaustor - 6:45h - 14 de junho - 2,0m

f) sem exaustor - altura de 2,0m

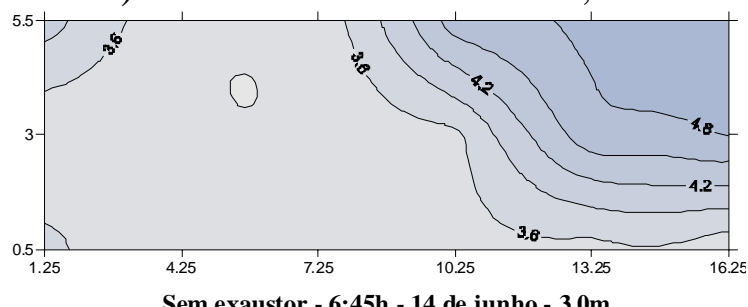

h) sem exaustor - altura de 3,0m

Figura 30-Cortes das isotermas nas alturas de 0,5, 1,0, 2,0 e 3,0 metros dos ambientes protegidos sem cultura, com as cortinas laterais fechadas e as frontais abertas com 1,0m de altura: a), c), e), e g) com apenas o exaustor eólico central aberto, e b), d), f), e h) sem exaustor eólico, no dia 14 de junho as 6:45h, horário de temperatura mais baixa

Nas Figuras 31(a) e 31(b) nos perfis verticais dos cortes 1 e 2, através das isotermas que representam as temperaturas médias no ambiente protegido com exaustores eólicos, podemos visualizar a ascensão dos fluxos de ar quente em direção abertura dos exaustores no teto da estrutura, evitando através da ventilação, o resfriamento do ar pela cobertura plástica. 
Nas Figuras 31(c), 31(d), 31(e) e 31(f) através das isotermas que representam os perfis verticais dos cortes 3, 4, 5 e 6, observa-se que os valores das temperaturas médias do ar, sofreram variações inferiores a $0,3^{\circ} \mathrm{C}$, que é o valor da escala entre as isotermas, mantendo a temperatura constante em todo o perfil vertical do ambiente protegido com exaustores eólicos.

No ambiente protegido com exaustores eólicos, as temperaturas do ar apresentaram médias no interior, entre 6,0 e $7,5^{\circ} \mathrm{C}$, enquanto a temperatura no ambiente externo era de $4,9^{\circ} \mathrm{C}$.

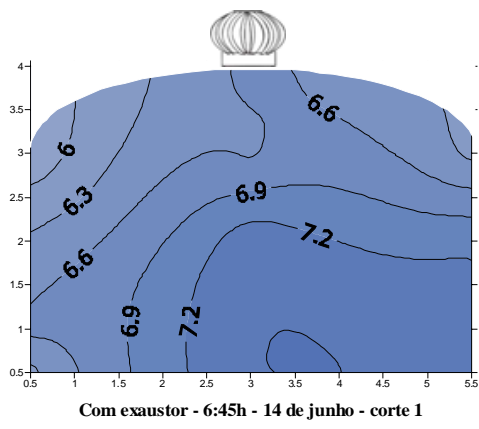

(a) com exaustor - corte 1

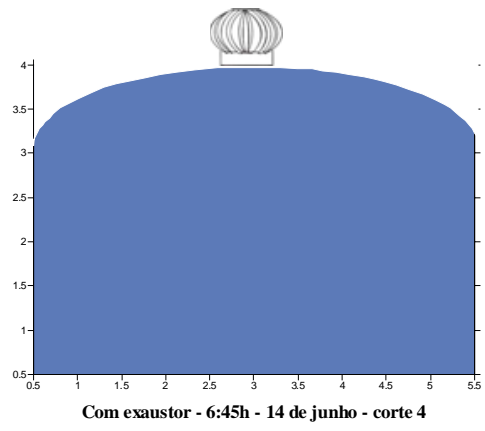

(d) com exaustor - corte 4

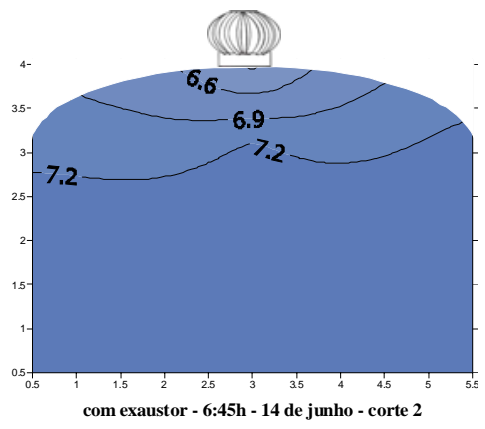

(b) com exaustor - corte 2

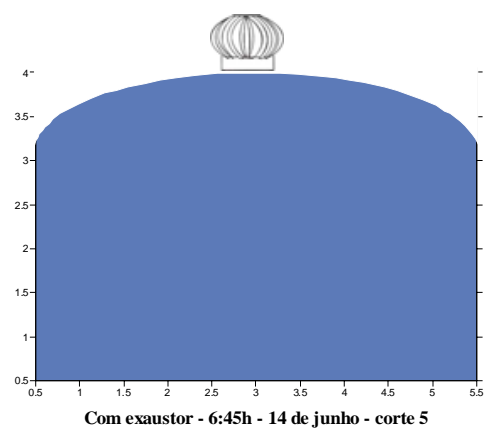

(e) com exaustor - corte 5

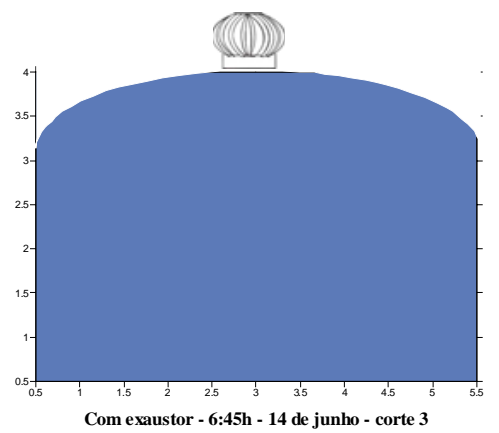

(c) com exaustor - corte 3

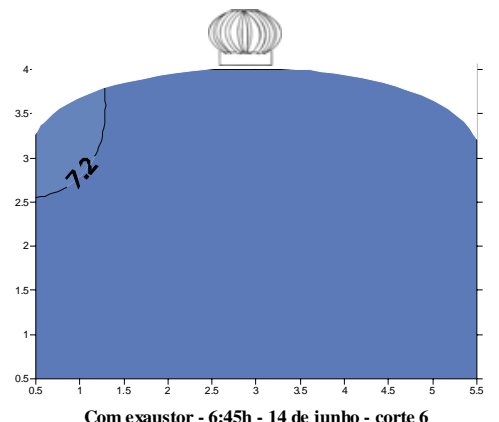

(f) com exaustor - corte 6

Figura 31-Cortes transversais do ambiente protegido com exaustores eólicos, sem cultura, com as cortinas laterais fechadas e as frontais abertas com 1,0m de altura no dia 14 de junho as 6:45h: (a) corte 1; (b) corte 2; (c) corte 3; (d) corte 4; (e) corte 5 e (f) corte 6

Nas Figuras 32(a), 32(b), através das isotermas que representam os perfis verticais dos cortes 1 e 2, observa-se que a massa de ar frio que se forma na cobertura 
plástica do ambiente, se locomove no sentido da superfície do solo, comprimindo e forçando os fluxos de ar quente para as saídas do lado direito do ambiente protegido.

Nas Figuras 32(c), 32(d), 32(e) e 32(f), através das isotermas que representam os perfis verticais dos cortes 3, 4, 5 e 6, nota-se que o fluxo de ar quente que é emitido pelo solo é pressionado pelas massas de ar frio que fazem com que se desloque para o alto e para o lado direito do ambiente protegido, até encontrar as laterais plásticas onde sofrerá resfriamento.

No ambiente protegido sem exaustor, as temperaturas do ar apresentaram médias no interior, entre 3,3 e $4,8^{\circ} \mathrm{C}$, enquanto a temperatura no ambiente externo era de $4,9^{\circ} \mathrm{C}$.

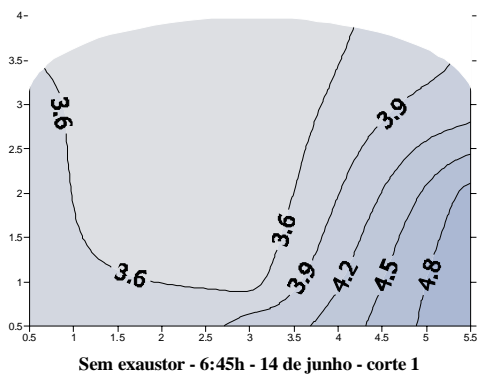

(a) sem exaustor - corte 1

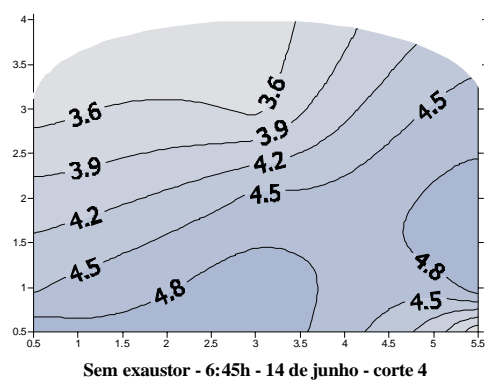

(d) sem exaustor - corte 4

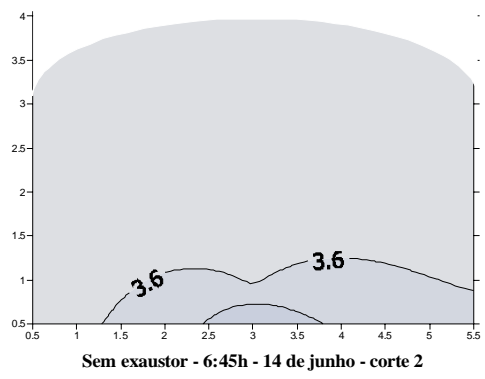

(b) sem exaustor - corte 2

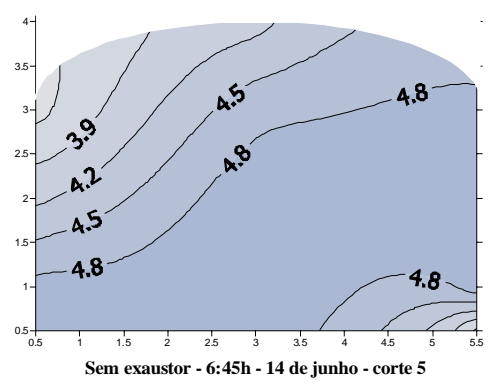

(e) sem exaustor - corte 5

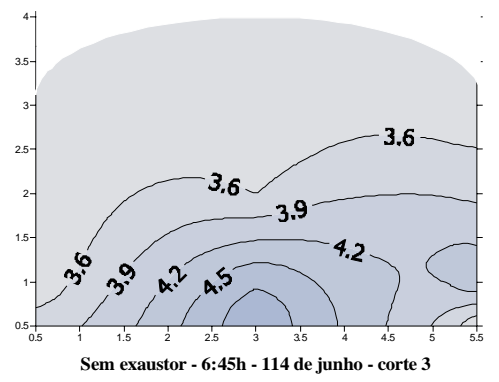

(c) sem exaustor - corte 3

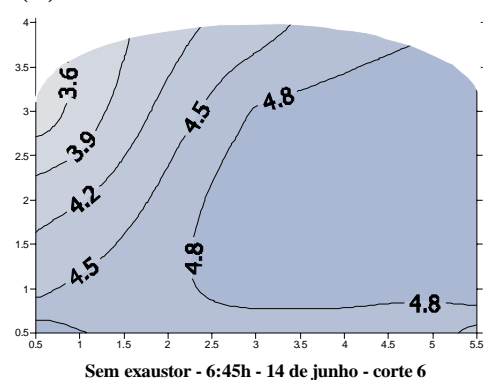

(f) sem exaustor - corte 6

Figura 32-Cortes transversais do ambiente protegido sem exaustor, sem cultura, com as cortinas laterais fechadas e as frontais abertas com 1,0m de altura no dia 14 de junho as 6:45h: (a) corte 1; (b) corte 2; (c) corte 3; (d) corte 4; (e) corte 5 e (f) corte 6 


\subsubsection{Cortinas laterais e frontais abertas com $1,0 \mathrm{~m}$ com apenas 0 exaustor central aberto.}

Fazendo a abertura com 1m das janelas laterais e frontais dos ambientes protegidos, e mantendo aberto apenas o exaustor eólico central, comparou-se à variação da temperatura média do ar nos dois ambientes no dia 21 de abril de 2004. Neste período ambos ambientes protegidos estavam sendo cultivados com pimentão, e a altura média da cultura de aproximadamente $1 \mathrm{~m}$.

Na Figura 33, verifica-se que a temperatura média do ar no decorrer do dia, no ambiente protegido com exaustores eólicos é praticamente igual a do ambiente sem exaustor. As pequenas diferenças ocorreram à noite, quando o ambiente com exaustor obteve as médias da temperatura um pouco mais altas que as do ambiente sem exaustor, e no período diurno, nos horários mais quentes do dia, as médias da temperatura do ambiente com exaustor eólico, ficam ligeiramente mais baixas que a do ambiente sem exaustor.

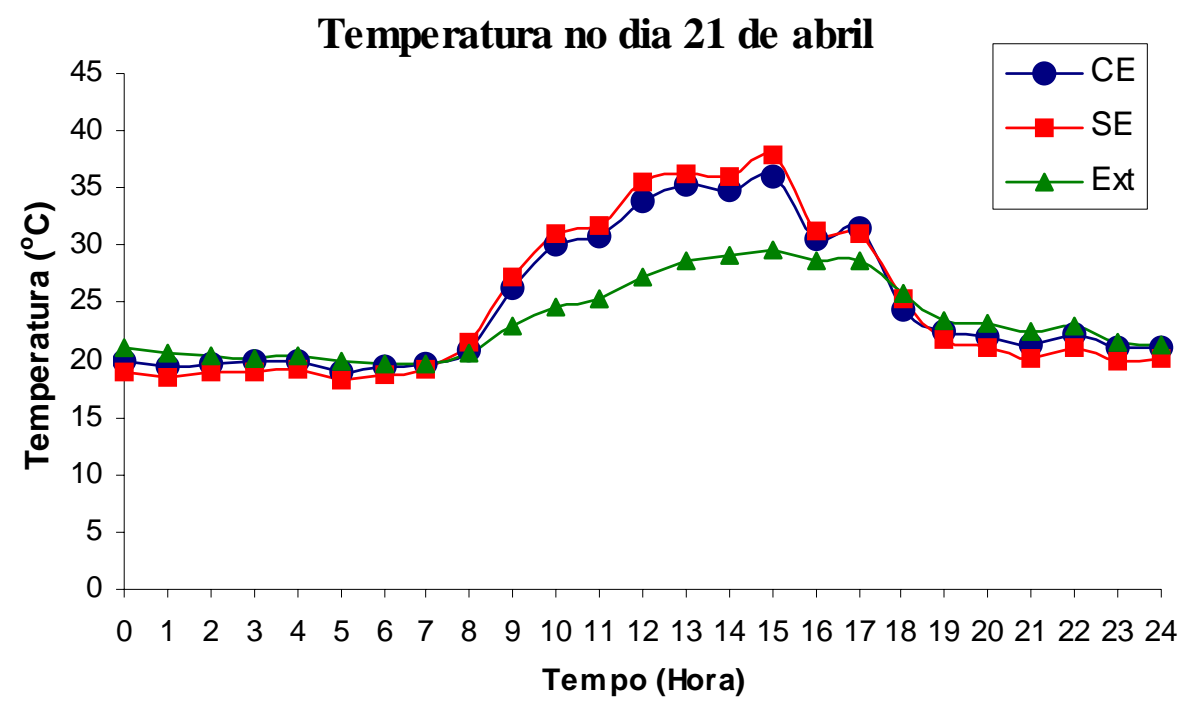

Figura 33-Temperaturas médias obtidas ao longo do dia 21 de abril, com as estufas cultivadas com pimentão, com as cortinas laterais totalmente fechadas, as cortinas frontais abertas com 1m de altura e apenas o exaustor eólico central aberto 
No horário de temperatura mais elevada, a temperatura média no ambiente externo foi de $30,3^{\circ} \mathrm{C}$, no ambiente sem exaustor a temperatura foi de $38,9^{\circ} \mathrm{C}$ ficando temperatura 28,4\% superior a externa e o ambiente protegido com os exaustores eólicos com $21,5 \%$.

Na Figura 34(a) e 34(b), visualiza-se a distribuição dos perfis verticais das temperaturas médias do ar no dia 21 de abril, no período das 6:00 as 18:00horas, e as 14:45h que foi o horário de maior temperatura média do dia.

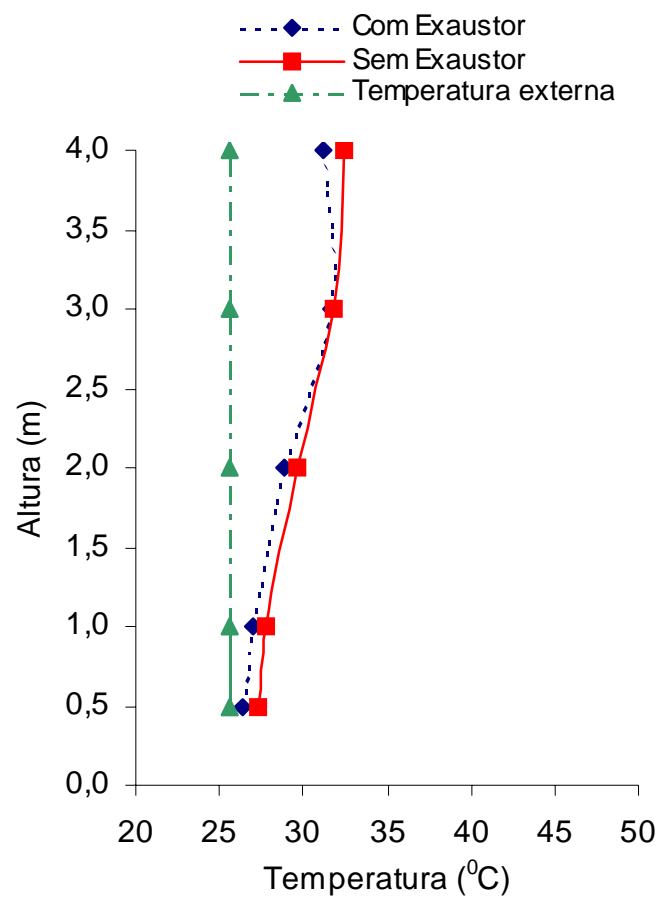

a) Temperatura média das 6:0018:00h do dia 21 de abril.

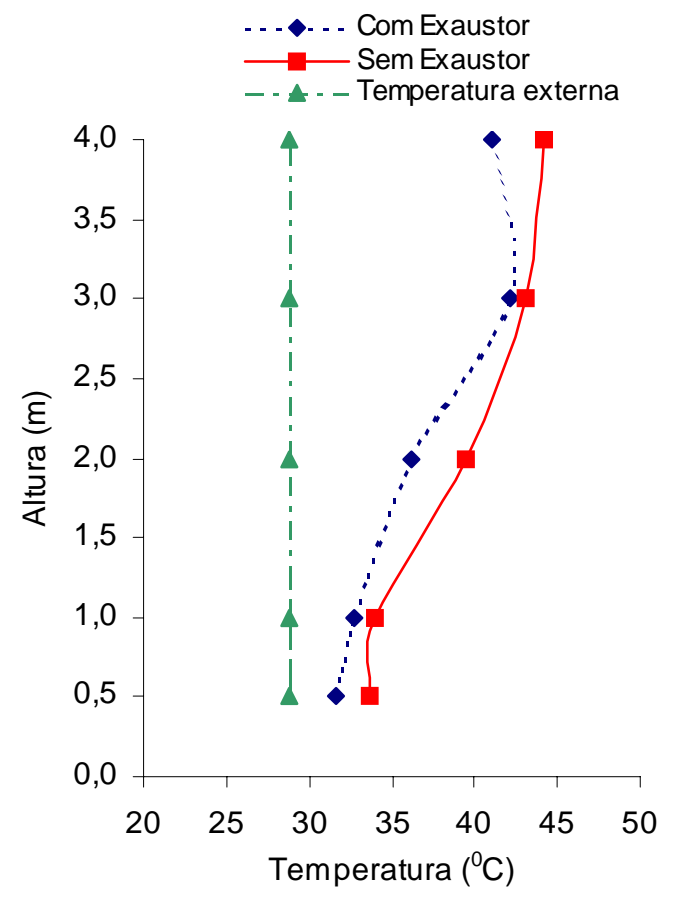

b) Temperatura média as 14:45 horas do dia 21 de abril.

Figura 34-Gráficos das temperaturas médias dos ambientes protegidos cultivados com pimentão, as janelas laterais fechadas e as janelas frontais abertas com 1,0m de altura, e apenas o exaustor central aberto, no dia 21 de abril nas alturas de $0,5 \mathrm{~m} ; 1,0 \mathrm{~m} ; 2,0 \mathrm{~m}$ e $3,0 \mathrm{~m}$.

Na Figura 35, nas isotermas traçadas a partir dos valores das temperaturas do ar nos termopares instalados longitudinalmente no centro dos ambientes protegidos, 
observa-se que apesar das temperaturas estarem elevadas nos dois ambientes, as temperaturas médias até a altura de 3,0m no interior do ambiente que está instalado o exaustor eólico, estão quase $2^{\circ} \mathrm{C}$ mais baixas e distribuídas de maneira mais uniforme que as do ambiente sem exaustor.

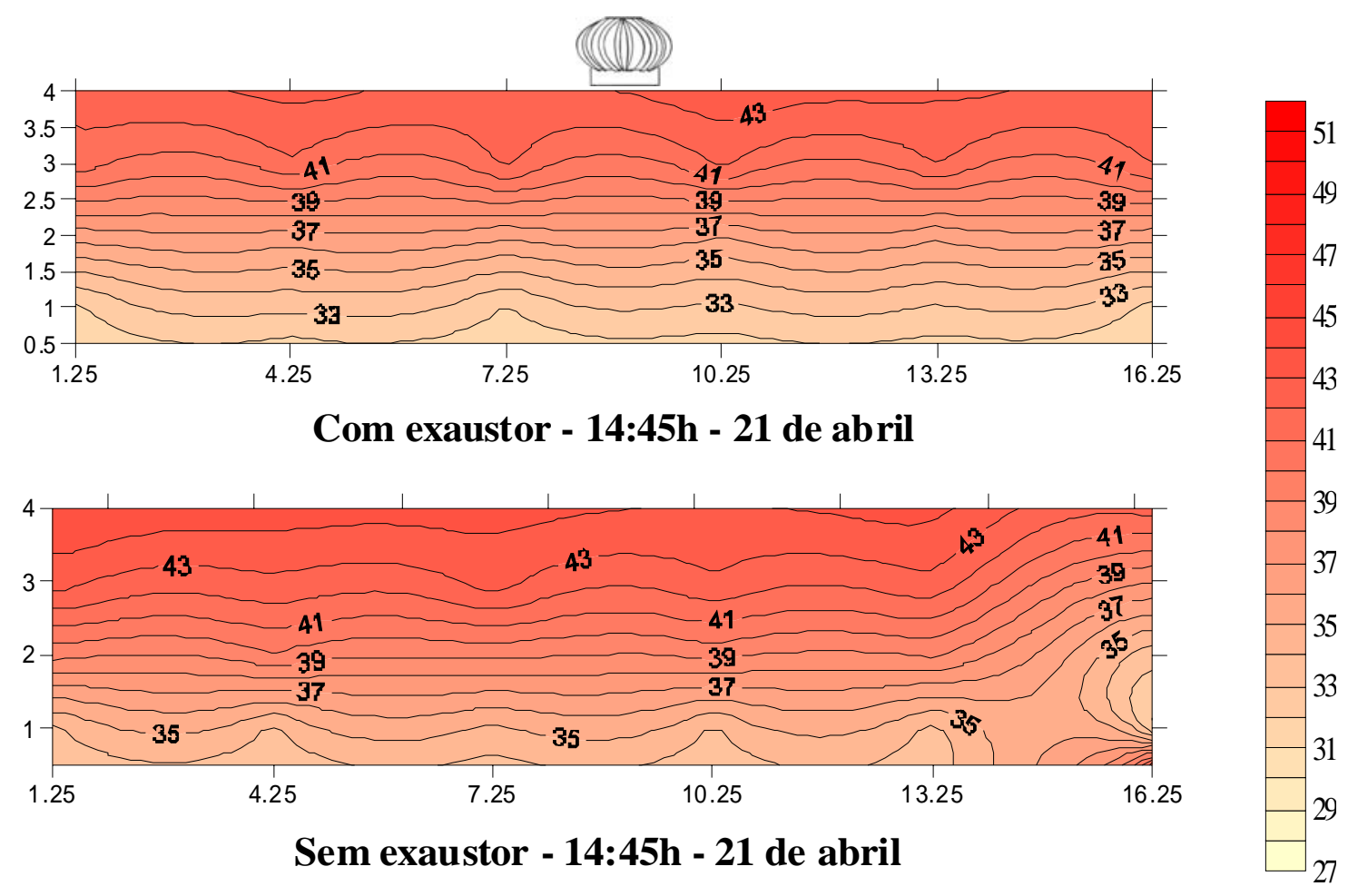

Figura 35-Corte longitudinal do vão central dos ambientes protegidos sem cultura, com as janelas laterais fechadas e as janelas frontais abertas com 1,0m de altura: (a) com apenas o exaustor eólico central aberto, e (b) sem exaustor eólico.

Na Figura 36 estão representadas as distribuições horizontais de temperatura do ar nas alturas de 0,5m, 1,0m, 2,0m e 3,0m da superfície do solo. Observa-se que no ambiente protegido com exaustores eólicos Figura 36(a), a temperatura do ar de aproximadamente $32^{\circ} \mathrm{C}$, está distribuída uniformemente por toda área, enquanto que o ambiente sem exaustor, na Figura 36(b), apresenta um gradiente na temperatura do ar, variando entre $33^{\circ} \mathrm{C}$ e $43^{\circ} \mathrm{C}$. Esta variação de temperatura pode ser devido a incidência de raios solares terem atingido diretamente os abrigos dos termopares provocando erros 
na leitura dos valores da temperatura pelos sensores instalados, pois o sentido do fluxo de calor registrado, é o oposto dos outros níveis de altura dentro do mesmo ambiente.

Nas Figuras 36(c) e 36(d) a distribuição horizontal de temperatura média do ar nos dois ambientes protegidos, seguem a mesma tendência, das médias de temperaturas estarem um pouco mais elevadas na área central dos ambientes.

Nas Figuras 36(e) e 36(g), que representam os perfis horizontais das temperaturas do ar nos níveis de 2,0 e 3,0m de altura no ambiente protegido com exaustor eólico, verifica-se um aumento significativo das temperaturas, na ordem de $6^{\circ} \mathrm{C}$ entre esses dois níveis, no sentido sul-norte do ambiente. A temperatura média do ar no ambiente protegido com exaustor variou no perfil, de $32^{\circ} \mathrm{C}$ a $0,5 \mathrm{~m}$ da superfície do solo a $43^{\circ} \mathrm{C}$ a $3,0 \mathrm{~m}$.

Na Figura 36(f), observa-se que o perfil horizontal apresenta variações elevadas nas temperaturas do ar a 2,0m de altura em toda extensão do ambiente protegido, variando em até $6^{\circ} \mathrm{C}$ nesta mesma altura, no sentido da direção norte para o sul, situação semelhante a do perfil horizontal da Figura 36(h), onde as diferenças no nível a 3,0m de altura variaram em $5^{\circ} \mathrm{C}$ na mesma direção. $\mathrm{O}$ sentido de aumento da temperatura é do norte para o sul, o contrário do encontrado no ambiente com exaustor eólico. 


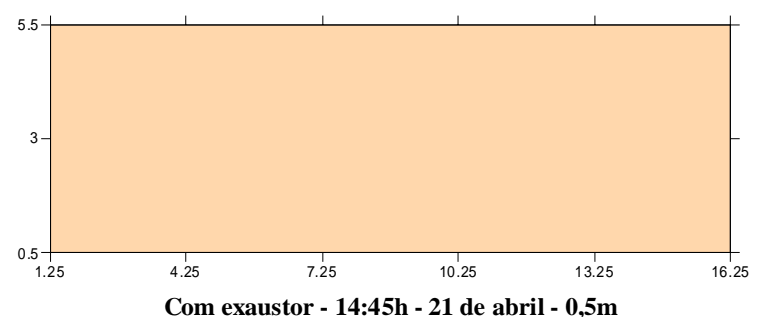

a) com exaustor - altura de $0,5 \mathrm{~m}$

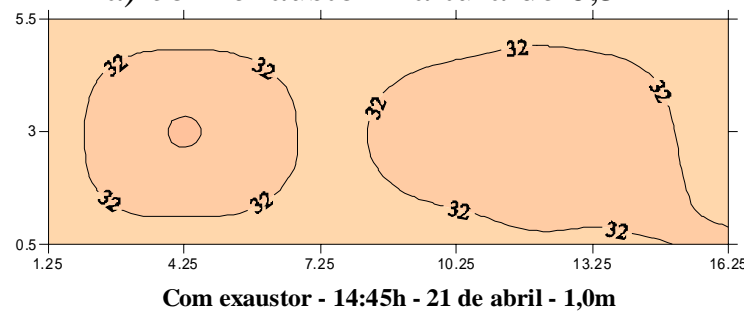

c) com exaustor - altura de $1,0 \mathrm{~m}$

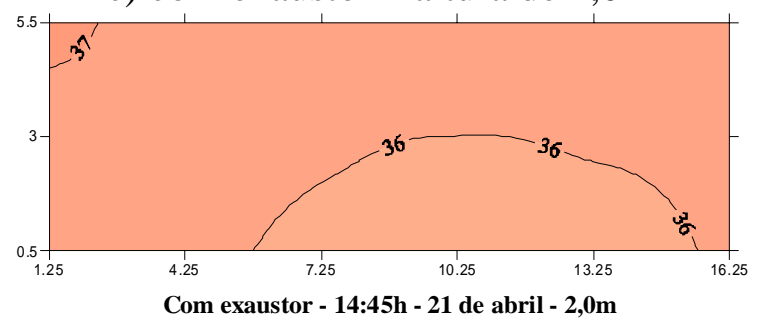

e) com exaustor - altura de 2,0m

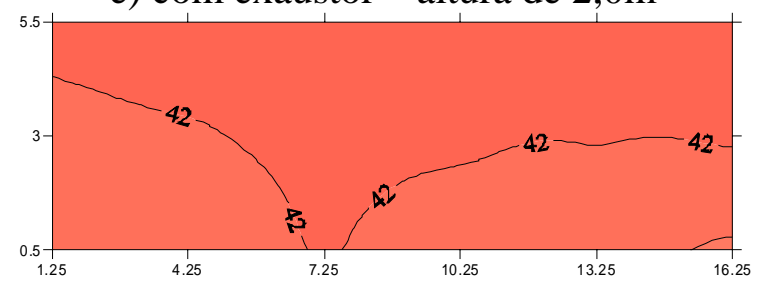

Com exaustor - 14:45h - 21 de abril - 3,0m

g) com exaustor - altura de 3,0m

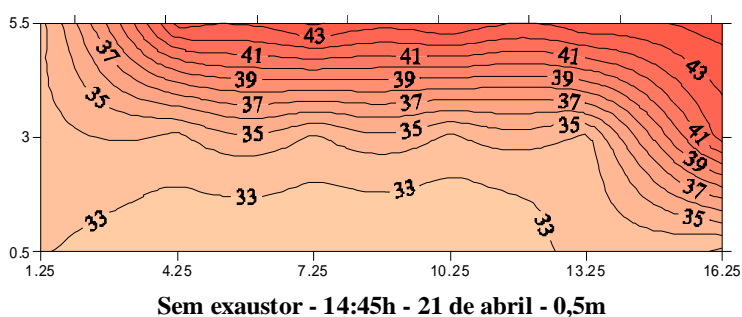

b) sem exaustor - altura de $0,5 \mathrm{~m}$

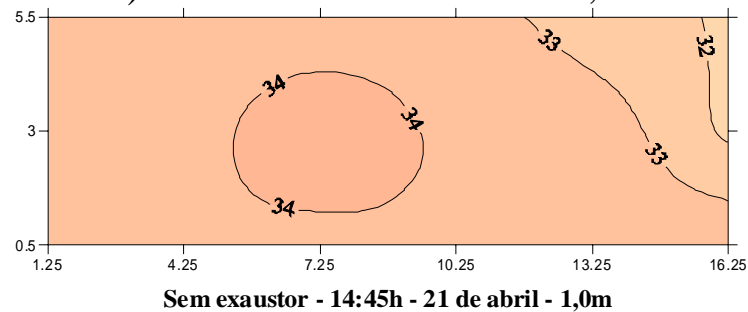

d) sem exaustor - altura de $1,0 \mathrm{~m}$

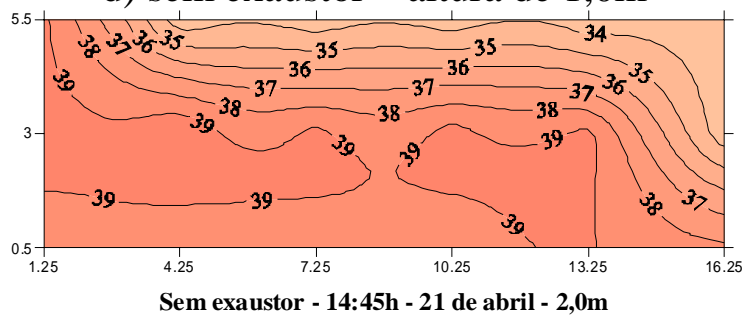

f) sem exaustor - altura de $2,0 \mathrm{~m}$

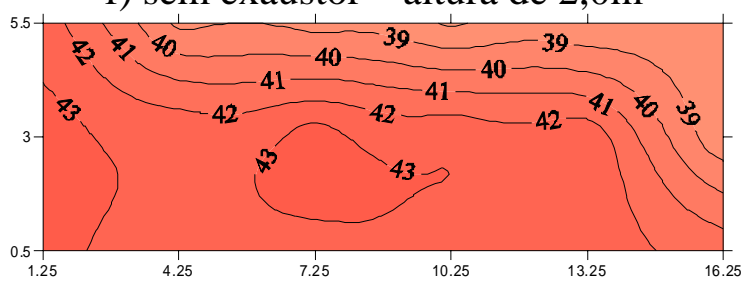

Com exaustor - 14:45h - 21 de abril - 3,0m

h) sem exaustor - altura de 3,0m

Figura 36-Cortes das isotermas nas alturas de 0,5, 1,0, 2,0 e 3,0 metros dos ambientes protegidos com as cortinas laterais fechadas e as frontais abertas com 1,0m de altura: a), c), e), e g) com apenas o exaustor eólico central aberto, e b), d), f), e h) sem exaustor eólico, as 14:45h do dia 21 de abril

Nas Figuras 37(a), (b), (c), (d), (e) e (f), observa-se que a distribuição das temperaturas representadas pelas isotermas no perfil vertical é bem uniforme, e com as temperaturas até o nível de abertura das cortinas, muito próximas da média da temperatura do ar no ambiente externo que era de $30,3^{\circ} \mathrm{C}$, neste horário. 


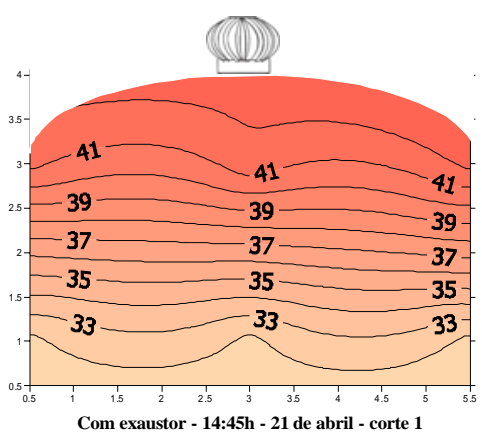

(a) com exaustor - corte 1

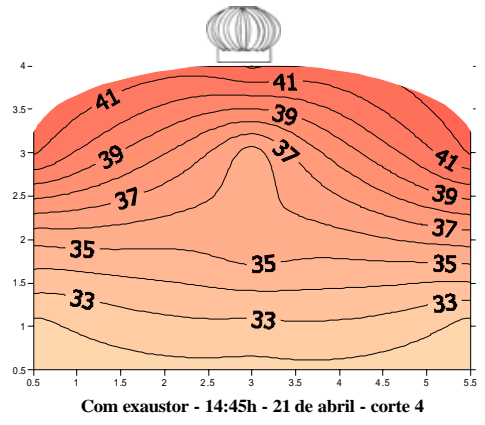

(g) com exaustor - corte 4

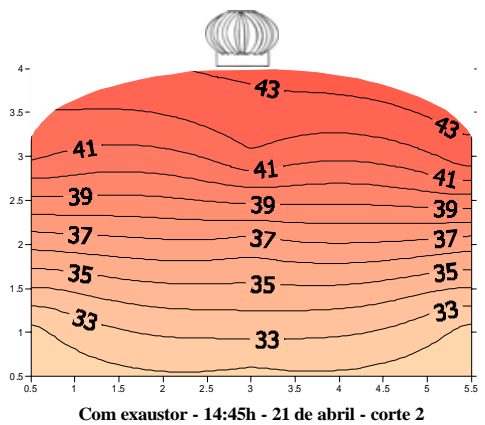

(b) com exaustor - corte 2

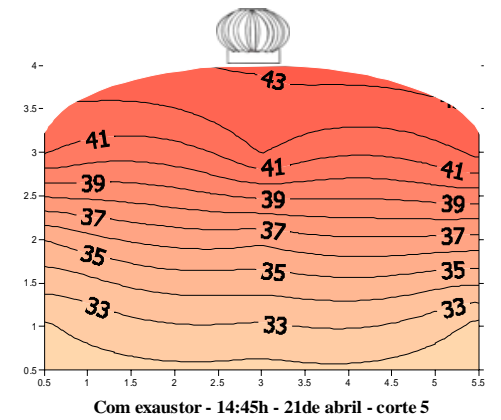

(h) com exaustor - corte 5

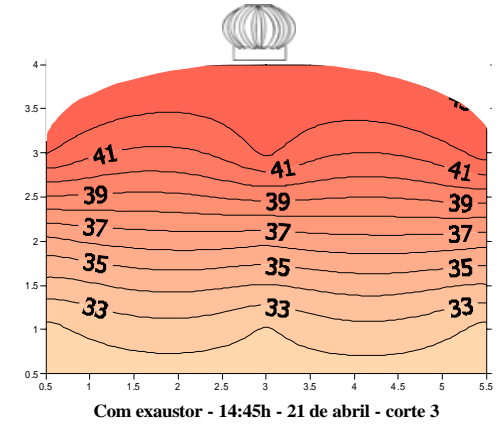

(c) com exaustor - corte 3

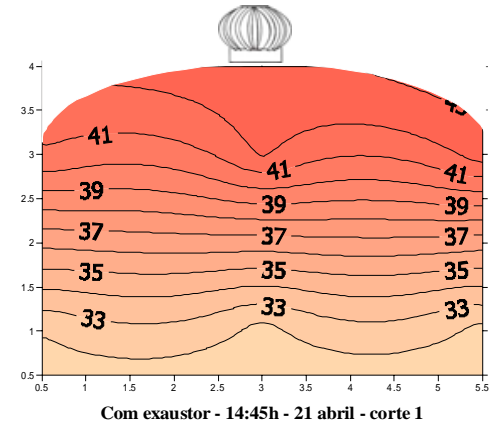

(i) com exaustor - corte 6

Figura 37-Cortes transversais do ambiente protegido com apenas o exaustor eólico central aberto, com as cortinas laterais fechadas e as frontais abertas com 1,0m de altura no dia 21 de abril as 14:45h: (a) corte 1; (b) corte 2; (c) corte 3; (d) corte 4; (e) corte 5 e (f) corte 6

Na Figura 38(a), as isotermas que representam o perfil vertical do corte 1 do ambiente sem exaustor apresentam uma distribuição da temperatura do ar bem uniforme, porém um pouco mais elevada que a do ambiente com exaustor.

Nas Figuras 38(b), 38(c), 38(d) e 38(e), nas isotermas que representam os perfis verticais dos cortes 2, 3, 4 e 5, nota-se que os fluxos de ar quente que são emitidos pelo solo ao encontrarem com a massa de ar que entra pelas aberturas da cortina lateral, se deslocam facilitando a formação de bolsões de ar no interior do ambiente sem exaustor, que podem ser observados na Figura 39(f). 


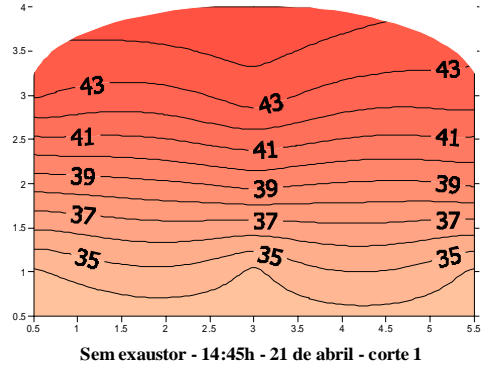

(a) Sem exaustor - corte 1

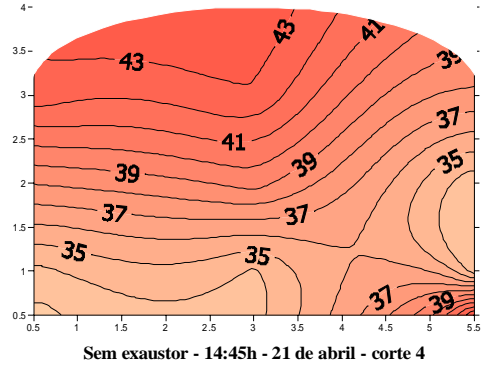

(d) Sem exaustor - corte 4

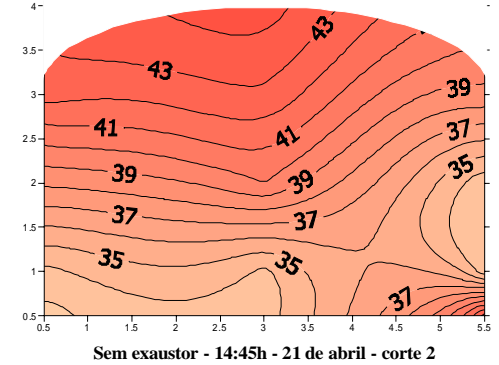

(b) Sem exaustor - corte 2

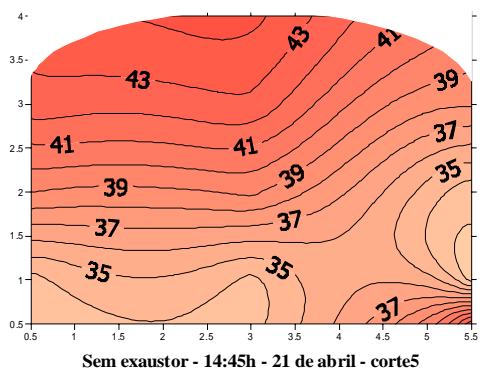

(e) Sem exaustor - corte 5

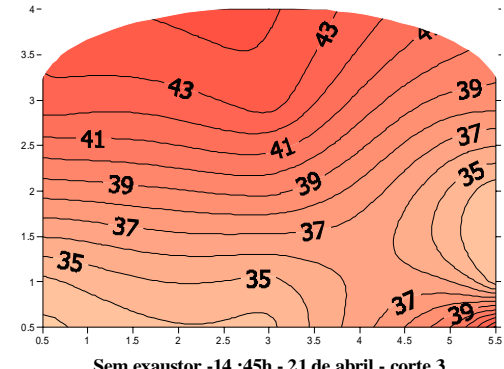

(c) Sem exaustor - corte 3

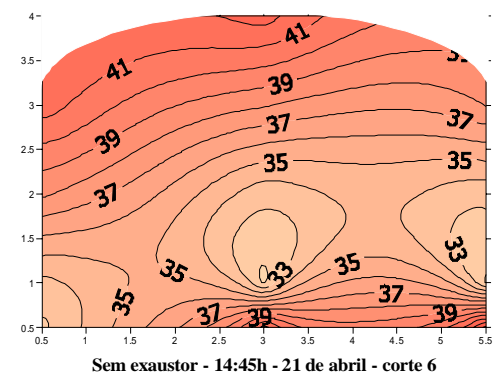

(f) Sem exaustor - corte 6

Figura 38-Cortes transversais do ambiente protegido sem exaustor, com as cortinas laterais fechadas e as frontais abertas com 1,0m de altura no dia 21 de abril as 14:45h: (a) corte 1; (b) corte 2; (c) corte 3; (d) corte 4; (e) corte 5 e (f) corte 6

\subsection{Determinação da capacidade de ventilação dos exaustores eólicos}

A capacidade de ventilação do ambiente protegido foi avaliada através do número de renovações do ar por hora, ou seja, o volume de ar que é renovado por unidade de tempo. Os equipamentos foram montados e os dados coletados dos dias 19 a 22 de outubro de 2004.

Foram avaliadas as medidas de velocidade do ar que passa por um exaustor ao qual foi adaptado um sistema de motor auxiliar, para garantir a velocidade constante de giro para efeito de comparações dos valores retirados com as cortinas abertas com 1m e com 0,5m de altura. Além do motor, foi instalado um sistema para executar a contagem de voltas do exaustor, para se determinar as rotações por minuto do equipamento.

Foram determinados valores de velocidade do vento que passa pela base de saída de ar do equipamento em duas situações distintas, para as condições de aberturas de 
cortinas: na primeira, com o exaustor se movendo apenas pela velocidade do vento externo, e na segunda, o motor instalado no exaustor era acionado à velocidade máxima e constante de giro do equipamento, que no caso foi de aproximadamente $120 \mathrm{rpm}$.

Os equipamentos que mediam as variáveis avaliadas foram instalados em apenas um dos exaustores eólicos, apesar dos três possuírem motores auxiliares, e os valores encontrados foram multiplicados pelo número de exaustores, no caso 3, para determinarmos o maior número de trocas de ar possível de ser realizada, utilizando os nossos equipamentos e nossas condições de trabalho.

Após os testes realizados, os valores demonstraram que, para a primeira situação, onde o exaustor era movimentado apenas pela energia eólica, o número de trocas de ar é maior com as cortinas abertas com 1,0m de altura, do que com as cortinas abertas a 0,5m. Estes valores podem ser visualizados na Figura 39.

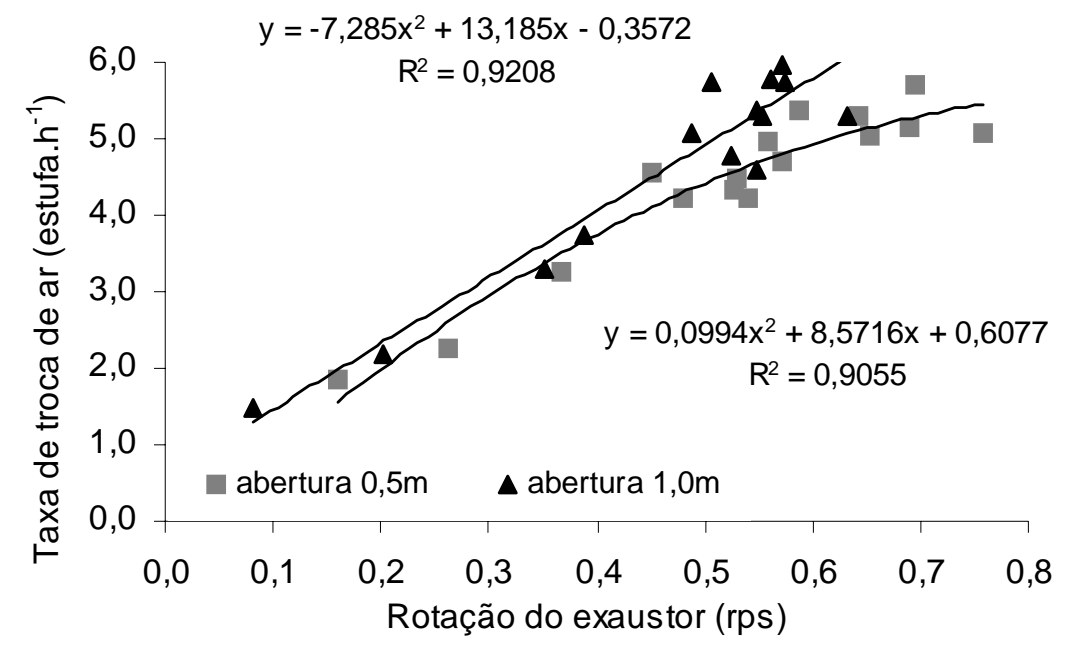

Figura 39- Gráfico da capacidade de ventilação dos exaustores eólicos, movidos apenas pela energia do vento, e com cortinas abertas a 1,0m e 0,5m

Para a segunda situação, onde o exaustor era movimentado por motor elétrico, os valores também demonstraram que o número de trocas é maior com as cortinas abertas com 1,0m de altura, do que com 0,5m de altura, e podem ser visualizados na Figura 40. 


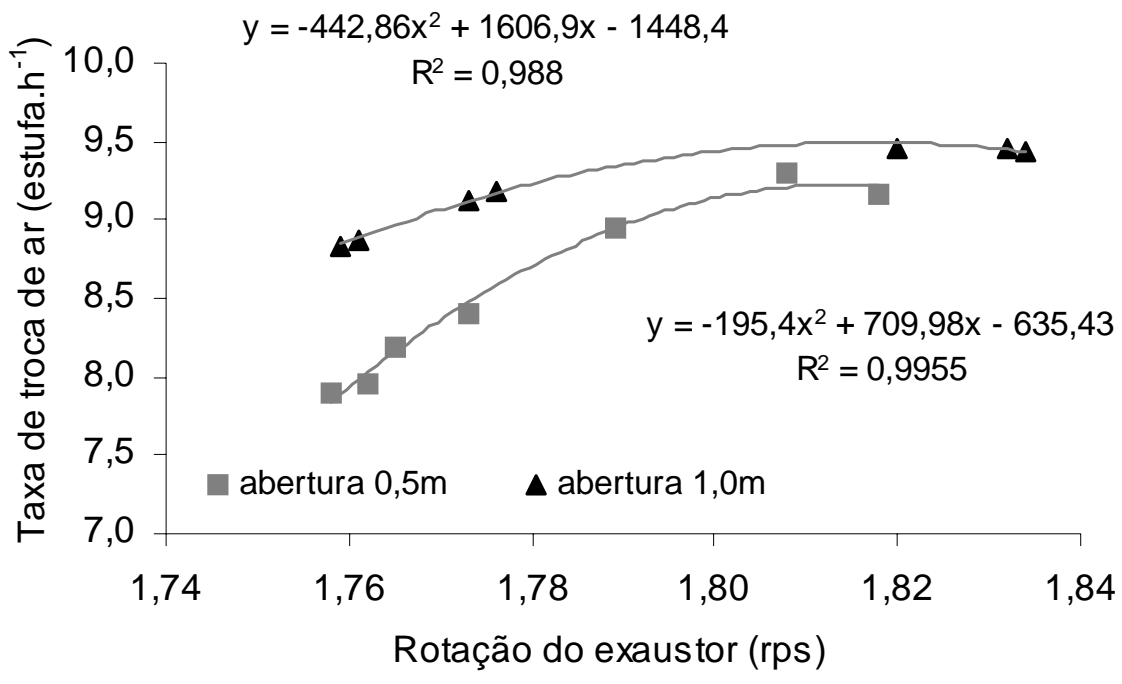

Figura 40-Gráfico da diferença da troca de ar em função da rotação do exaustor, com a abertura das cortinas laterais e frontais a $1,0 \mathrm{~m}$ e a $0,5 \mathrm{~m}$ de altura

Após a determinação da capacidade de ventilação dos exaustores instalados no ambiente protegido, que mesmo utilizando os motores auxiliares, ficou na ordem de aproximadamente 10 trocas.hora $^{-1}$, verificamos que os valores não corresponderam com a capacidade de troca de ar fornecida pelo fabricante, quando do dimensionamento do projeto de ventilação, que calculou-se para ser de aproximadamente 30 trocas.hora $^{-1}$. Dentre varias hipóteses levantadas, uma parece ter bastante influência nessa redução no volume de trocas, a presença de telas sombrite a 60\% nas laterais dos ambientes protegidos que reduzem consideravelmente a entrada de ventilação no seu interior, situação que normalmente não é encontrada nos locais que normalmente utilizam esses equipamentos.

Essa hipótese foi despertada durante os testes quando aumentávamos a rotação do motor e conseqüentemente, as rotações do exaustor, as velocidades de saída do ar, não se alteravam significativamente, como ocorria quando da diminuição da rotação do motor e aumento das aberturas das cortinas. Esse fato justifica também a maior eficiência das trocas de ar com as cortinas abertas com 1,0m sobre as abertas com $0,5 \mathrm{~m}$, que seria o aumento da capacidade de entrada de ar para o interior do ambiente. 


\subsubsection{Determinação do número de rotações para fazer uma troca de ar no ambiente.}

Com os valores utilizados nos cálculos da eficiência da ventilação, construímos dois gráficos de rotação do exaustor por hora $\mathrm{x}$ taxa de ventilação em volume do ambiente por hora, e determinamos pela equação de regressão linear, o número de rotações necessárias para renovar uma vez todo o ar do ambiente, utilizando apenas a energia do vento e a energia de motores, no mesmo dia e com as cortinas abertas com 1,0m de altura.

Utilizando os valores das equações da regressão linear, das Figuras 41(a) e 41(b), calculamos que para os exaustores movidos por motores auxiliares trocarem todo o ar do ambiente protegido, serão necessárias 714,3 rotações, e para o exaustor movido apenas pela energia dos ventos, serão necessárias 416,7 rotações. Porém esses valores não servem para avaliar a eficiência dos sistemas, se o fator tempo também for importante na operação. A vantagem do sistema motorizado é que apesar do maior número de rotações necessárias para remover o mesmo volume de ar, ele o faz num tempo menor.

Os gráficos de: rotação x taxa de ventilação, com as respectivas equações de regressão linear, podem ser visualizados na Figura 41. 


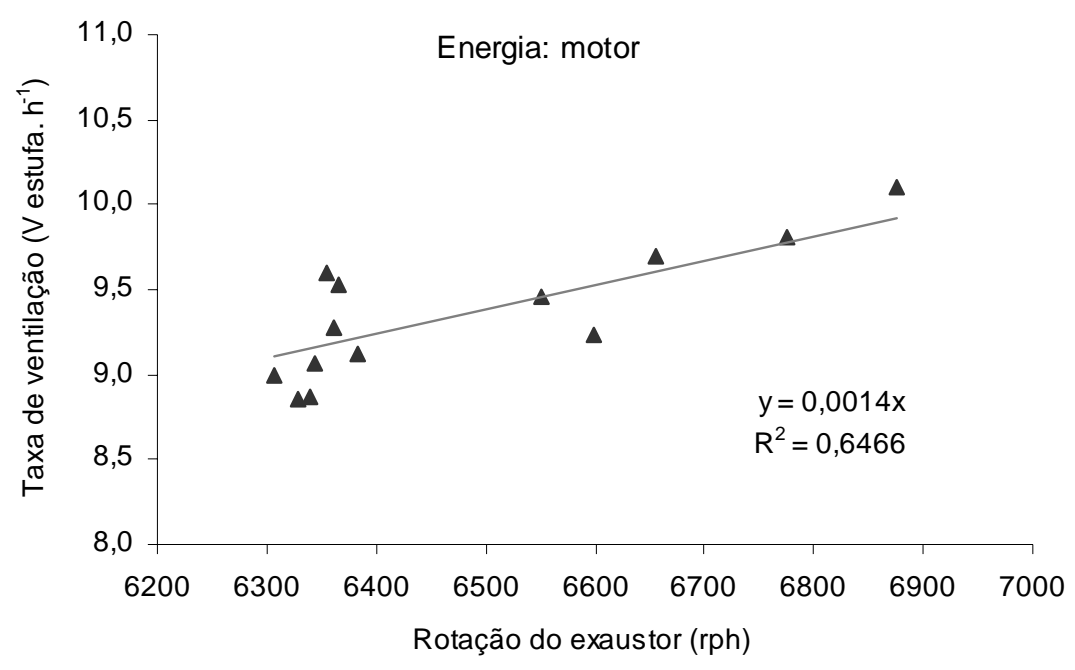

(a)

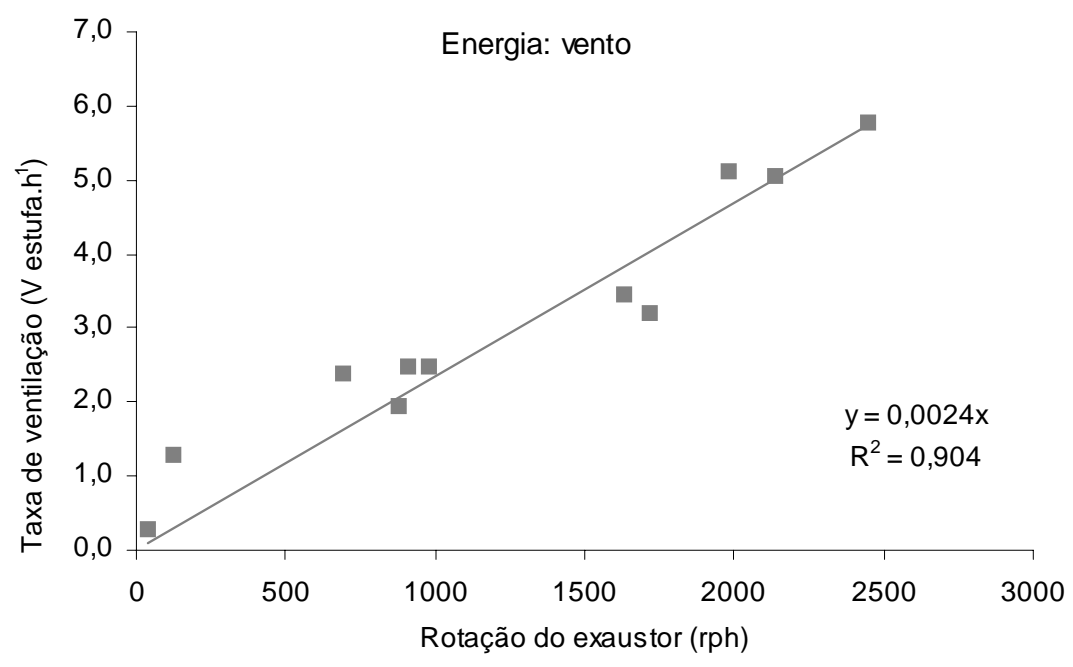

(b)

Figura 41-Gráficos de eficiência: rotação x taxa de ventilação, para: (a) exaustores eólicos movidos por motor, e (b) exaustores eólicos movidos apenas pelo vento 


\section{CONCLUSÕES}

- Utilização de exaustores eólicos para controle de temperatura do ar.

A utilização de exaustores eólicos em ambientes protegidos, apesar de não reduzir significativamente a temperatura do ar nos períodos diurnos, mostrou-se eficaz no controle das temperaturas do ar, melhorando a sua distribuição tanto no perfil vertical como no horizontal, deixando-a uniforme, principalmente na altura da abertura das cortinas. No período noturno, principalmente nas noites de temperaturas mais baixas, manteve as temperaturas internas superiores ao outro ambiente protegido, e ao ambiente externo em até $4^{\circ} \mathrm{C}$. A combinação do manejo de cortinas e do uso de exaustores eólicos auxiliador por motor, que funcionam tanto com a energia do vento quanto com eletricidade para utilização nos momentos de aumento de temperatura ou falta de ventos, podem contribuir na redução da temperatura.

- Utilização de exaustores eólicos para controle da ventilação.

A utilização dos exaustores eólicos melhora o controle da ventilação otimizando o "efeito termo sifão" ou processo convectivo, através do manejo adequado das cortinas, independente da direção e velocidade dos ventos. A taxa de ventilação do ambiente protegido no experimento com os exaustores movimentados apenas pelo vento foi de $0 \mathrm{a}$ 5 trocas por hora, enquanto que, utilizando os motores auxiliares a taxa foi de 9 a 11 trocas por hora.

A análise da distribuição da temperatura do ar por meio de isotermas permitiu uma visão global instantânea do efeito dos exaustores eólicos retirando a massa de ar quente instalada próxima à cobertura do ambiente protegido, e da melhora da distribuição de temperatura do ar, tornando-a mais uniforme e homogênea. 


\section{REFERÊNCIAS BIBLIOGRÁFICAS}

ABREU, P.G. de; ABREU, V.M.N.; MAZZUCO, H. Uso do resfriamento evaporativo (adiabático) na criação de frangos de corte. Concórdia: EMBRAPACNPSA, 1999. 51p. (EMBRAPA-CNPSA. Documentos, 59).

AL-JAMAL, K. Greenhouse cooling in hot countries. Energy, v.19, n.11, p.1187-1192, 1994.

ANDRIOLO, J.L.; BURIOL, G.A.; ESTEFANEL, V. et al. Determinação das variações de temperatura do ar e do solo e da umidade relativa do ar no ambiente interno e externo de uma estufa de polietileno em Santa Maria, RS. In: ENCONTRO DE PLASTICULTURA DA REGIÃO SUL, 3, Curitiba, PR, 1989. Resumos Curitiba: Emater-PR, 1989. p. 6.

ANTON VALlEJO, A.; MONTERO CAMACHO, J.I.; BIEL LOSCOS, C. Refrigeración de invernaderos, Humidificación. Hortofruticultura, v.4, p.59-62, 1992.

ATARASSI, R.T. Modelagem do microclima em casa-de-vegetação. Piracicaba, 2000. 96p. Dissertação (Mestrado) - Escola Superior de Agricultura “Luiz de Queiroz”, Universidade de São Paulo.

BAILEY, B.J. Microclimate, physical processes and greenhouse technology. Acta Horticulturae, v.174, p.35- 42, 1985.

BERNINGER, E. Cultures Florales de serre en zone mediterraneenne française. Paris: INRA, 1989.252 p. 
BOULARD, T.; BAILLE, A. A simple greenhouse climate control model incorporating effects of ventilation and evaporative cooling. Agricultural and Forest Meteorology, v.65, n.3-4, p.145-157, 1993.

BOULARD, T.; RAZAFINJOHANY, E.; BAILLE, A.; JAFFRIN, A.; FABRE, B. Performance of greenhouse heating system with a phase change material. Agricultural and Forest Meteorology, Amsterdan, v. 52, p. 303-318, 1990

CAMACHO, M.J.; ASSIS, F.N. de; MARTINS, S.R.; MENDEZ, M.E.G. Avaliação de elementos meteorológicos em estufa plástica em pelotas, RS. Revista Brasileira de Agrometeorologia, v.3, p.19-24, 1995

CERMEÑO, Z.S. Construcción de invernaderos. Madrid: Mundi-Prensa, 1994. 445p.

DELLA VECCHIA, P.T.; KOCH, P.S. História e perspectivas da produção de hortaliças em ambientes protegidos no Brasil. Informe Agropecuário, v.20, n.200/201, set/dez. 1999.

FARIAS, J.R.B.; BERGAMASHI, H.; MARTINS, S.R.; BERLATO, M.A. Efeito da cobertura plástica de estufa sobre a radiação solar. Revista Brasileira de Agrometeorologia, v.1, n.1, p.31-36, 1993a.

FARIAS, J.R.B.; BERGAMASCHI, H.; MARTINS, S.R.; BERLATO, M.A.; OLIVEIRA, A.C.B. Alterações na temperatura e umidade relativa do ar provodas pelo uso de estufa plástica. Revista Brasileira de Agrometeorologia, v.1, n.1, p.51-62, 1993b.

FARIAS, J.R.B.; BERGAMASHI, H.; MARTINS, S.R. Evapotranspiração no interior de estufas plásticas. Revista Brasileira de Agrometeorologia, v.2, p.17-22, 1994.

FERNANDES, A.L.T. Monitoramento da cultura do crisântemo em estufa através do uso de lisímetro e estação agrometeorológica automatizada. Piracicaba, 1996. 96p. Dissertação (Mestrado) - Escola Superior de Agricultura "Luiz de Queiroz", Universidade de São Paulo. 
FOLEGATTI, M.V.; SCATOLINI, M.E.; PAZ, V.P.S.; PEREIRA, A.R.; FRIZZONE, J.A. Efeitos da cobertura plástica sobre os elementos meteorológicos e evapotranspiração da cultura de crisântemo em estufa. Revista Brasileira de Agrometeorologia, v.5, n.2, p.155-163, 1997.

FRISINA, V.A.; ESCOBEDO, J.F. Balanço de radiação e energia da cultura de alface em estufa de polietileno. Pesquisa Agropecuária Brasileira, v.34, n.10, p.17751786, out. 1999.

FURLAN, R.A. Avaliação da nebulização e abertura de cortinas na redução da temperatura do ar em ambiente protegido. Piracicaba, 2001. 146p. Tese (Doutorado) - Escola Superior de Agricultura "Luiz de Queiroz", Universidade de São Paulo.

HELLICKSON, M.A. \& WALKER, J.M. Ventilation of agricultural structures. ASAE Technical Editor: James A. Basselmam, 362p. 1983. 362p. (ASAE Monograph, number 6)

HERTER, F.G.; REISSER JUNIOR, C. Balanço térmico em estufas plásticas em Pelotas, RS. Horticultura Brasileira, v. 5, n. 1, p. 60, 1987

KITTAS, C. Estimation des besoins d’aération des serres en Gréce. Agronomie, v. 6, n. 7, p. 629-632, 1986.

KITTAS, C. A simple climagraph for characterizing regional suitability for greenhouse cropping in Greece. Agricultural and Forest Meteorology, v. 78, p. 133-141, 1996.

MARTIN, E.C.; NOVOA, A.C.; GOMES, S.J. Estudio comparativo de las propriedades de diversos materiales utilizados como cobertura en cultivos protegidos. Revista de Plásticos Modernos, v.308, p.185-189, 1982.

MARTINEZ GARCIA, P.F. Características climaticas de los invernaderos de plástico. Madrid: Instituto Nacional de Investigaciones Agrarias-INIA, 1978. 48p. (Hoja Tecnica, 19.) 
MARTINEZ GARCIA, P.F. La regulación de las condidiones del ambiente en los cultivos protegidos. In: FERIA TECNICA INTERNACIONAL DE LA MAQUINARIA AGRÍCOLA, Zaragoza, 1986. Anais. Zaragoza: Associación Nacional de Ingenieros Agronomos, 1986. p. 135-147.

MARTINS, S.R.; GONZALEZ, J.F. Avaliação do resfriamento em estufa plástica mediante sistema de ventilação e nebulização. Revista Brasileira de Agrometeorologia, v. 3, p. 13-18, 1995.

MATALLANA GONZALES, A.; MARFA PAGES, J.O. Los Invernaderos y la crisis energética. Madrid: INIA.M.A., 1980, 132 p.

MATALLANA GONZALES, A.; MONTERO CAMACHO, J.I. Invernaderos: Diseño, construcción y ambientación. Madri: Mundi-Prensa, 1993. 159p.

MENESES, J.F.; RAPOSO, J.R. Ventilação natural de instalações agrícolas: teoria e métodos de cálculo. Anais do Instituto Superior de Agronomia, v.42, p.249-265, 1985/87.

MONTERO CAMACHO, J.I.; ANTÓN VALLEJO, A.; BIEL LOSCOS, C. Refrigeración de vnvernaderos, ventilación natural. Hortofruticultura, v. 6, p. 6971, 1992.

MONTERO, J.I.; ANTÓN, A. Greenhouse cooling during warm periods. Acta Horticulturae, v.357, p.49-61, 1994.

MONTERO, J.I.; CASTILLA, N.; GUTIERREZ de RAVÉ, E.; BRETONES, F. Climate under plastic in the Almeria. Acta Horticulturae, v. 170, p.227-234, 1985.

OLIVEIRA, C.R. Cultivo em ambiente protegido. Boletim Técnico CATI, n.232, p.131, abr 1997.

OLIVEIRA, M.R.V. de O emprego de casas de vegetação no Brasil: Vantagens e desvantagens. Pesquisa Agropecuária Brasileira, v.30, n.8, p.1049-1060, ago.1995. 
PEZZOPANE, J.E.M.; PEDRO JR, M.J.; ORTOLANI, A.A. Modificações microclimáticas provocadas por estufas com cobertura plástica. Bragantia, v.54, p.419-425, 1995.

PRADOS, N.C. Contribución al estudio delos cultivos enarenados en Almeria: necessidades hídricas y extración del nutrientes del cultivo de tomate de crescimento indeterminado en abrigo de polietileno. Almeria, Es, 1986. 195p. Tesis (Doutorado), Caja Rural Provincial.

ROBLEDO, F.P.; MARTIN, L.V. Aplicación de los plásticos en la agricultura. Madrid: Mundi-Prensa. 1981. 552 p.

SCHNEIDER, F.M.; BURIOL, G.A.; CARLET, F.; STRECK, L.; HELDWEIN, A.B. Tecnologia para diminuir temperaturas excessivamente elevadas no interior de estufas plásticas. Revista Brasileira de Agrometeorologia, v. 6, n. 2, p. 285-287, 1998.

SEEMANN, J. Greenhouse Climate. In: SEEMAN, J. Agrometeorology. Heidelberg, Germany: Springer-Verlag,. 1979.p. 165-178.

SENTELHAS, P.C.; VILLANOVA, N.A.; ANGELOCCI, L.R. Efeito de diferentes tipos de cobertura, em mini-estufas, na atenuação da radiação solar e da luminosidade. In: CONGRESSO BRASILEIRO DE AGROMETEOROLOGIA, 10. Piracicaba, 1997. Anais. Piracicaba: Sociedade Brasileira de Agrometeorologia. 479-481.

SOUZA, J.L. de; ESCOBEDO, J.F. Balanço de energia em cultivos de feijão-vagem com e sem cobertura de polietileno. Pesquisa Agropecuária Brasileira, v.32, n.1, p.1-15, jan.1997.

SOUZA, J.L de.; ESCOBEDO, J.F.; TORNERO, M.T.T. Albedo e estimativa do saldo de radiação em feijão-vagem sob cobertura de plástico e ambiente externo. Pesquisa Agropecuária Brasileira, v.34, n.10, p.1763-1774, out. 1999.

TANAKA, M.; GENTA, H. Control del médio ambiente baho invernadero y túnel plástico. Salto. Uruguay: Estacion Experimental de Citricultura, 1982.61p. 
TAPIA, G.J. Filmes térmicos para invernaderos. Revista de los Plásticos Modermos, v. 295, p. 75-82, 1981.

TRIKI, J.; VERLODT, H.; BAETEN, S. Influence de differents systemes d'aeration sur la distribution des temperatures sous serre polyethylene. Acta Horticulturae, v.154, p.241-248, 1984.

VANHOUTTE, S.; VERLODT, H. Comparison of polynomial regression and linear interpolation as methods for temperature distribution studies under greenhouses. Acta Horticulturae, v.281, p.211-229, 1990.

VILLELE, O. Le contexte climatique et cultural de la serre. 1 - La serre, agent de modification du climat.Paris: Institut Nacional de la Recherche Agronomique, 1983. p. 21-27. 